UNIVERSIDADE ESTADUAL PAULISTA

"JÚLIO DE MESQUITA FILHO"

INSTITUTO DE BIOCIÊNCIAS, LETRAS E CIÊNCIAS EXATAS.

CAMPUS DE SÃO JOSÉ DO RIO PRETO/SP

JULIANA GUERRA DE OLIVEIRA

PRODUÇÃO DE BIOSSURFACTANTE POR Bacillus pumilus

E AVALIAÇÃO DA BIORREMEDIAÇÃo DE SOLO E ÁGUA CONTAMINADOS

COM ÓLEO

São José do Rio Preto - SP.

2010 
PRODUÇÃO DE BIOSSURFACTANTE POR BACILLUS PUMILUS

E AVALIAÇÃO DA BIORREMEDIAÇÃO DE SOLO E ÁGUA CONTAMINADOS COM ÓLEO

Orientador: Prof. Dr. Crispin Humberto Garcia Cruz

Dissertação apresentada como parte dos requisitos para obtenção do título de Mestre em Microbiologia, junto ao Programa de Pós-Graduação em Microbiologia, Área de Concentração - Microbiologia, do Instituto de Biociências, Letras e Ciências Exatas da Universidade Estadual Paulista "Júlio de Mesquita Filho", Campus de São José do Rio Preto - SP.

São José do Rio Preto - SP 
Oliveira, Juliana Guerra de.

Produção de biossurfactante por Bacillus pumilus e avaliação da biorremediação de solo e água contaminados com óleo / Juliana Guerra de Oliveira. - São José do Rio Preto : [s.n.], 2010.

$70 \mathrm{f} . ; 30 \mathrm{~cm}$.

Orientador: Crispin Humberto Garcia Cruz

Dissertação (mestrado) - Universidade Estadual Paulista, Instituto de Biociências, Letras e Ciências Exatas

1. Bioprocessos - Microbiologia. 2. Bacillus pumilus - Microbiologia. 3. Biossurfactante - produção. 4. Biorremediação. 5. Águas residuais - Purificação Tratamento biológico. I. Garcia Cruz, Crispin Humberto. II. Universidade Estadual Paulista, Instituto de Biociências, Letras e Ciências Exatas. III. Título.

CDU -543.395

Ficha catalográfica elaborada pela Biblioteca do IBILCE

Campus de São José do Rio Preto - UNESP 
JULIANA GUERRA DE OLIVEIRA

\section{PRODUÇÃO DE BIOSSURFACTANTE POR BACILLUS PUMILUS E AVALIAÇÃO DA BIORREMEDIAÇÃO DE SOLO E ÁGUA CONTAMINADOS COM ÓLEO}

Dissertação apresentada para obtenção do título de Mestre em Microbiologia, junto ao Programa de Pós-Graduação em Microbiologia, Área de Concentração - Microbiologia do Instituto de Biociências, Letras e Ciências Exatas da Universidade Estadual Paulista "Júlio de Mesquita Filho", Campus de São José do Rio Preto.

BANCA EXAMINADORA

Prof. Dr. Crispin Humberto Garcia Cruz UNESP - São José do Rio Preto Orientador

Prof. Dr. Benício Alves de Abreu Filho Universidade Estadual de Maringá - UEM/ PR

Prof $^{\mathrm{a}}$. Dr ${ }^{\mathrm{a}}$. Eleni Gomes

UNESP - São José do Rio Preto

São José do Rio Preto, 10 março de 2010. 


\section{Dedico e Ofereço}

Ao meu tio Antônio Guerra, a minha mãe Roseli Guerra e ao meu irmão Júlio Cézar Guerra. Não existe mais nada importante do que a força da família. Amo vocês... 


\section{Agradecimentos}

Agradeço a Deus por ter me dado força todas as vezes que pensei em desistir.

À minha mãe Roseli Guerra por toda atenção e amor, ao meu tio Antônio Guerra pela dedicação, apoio e carinho, ao meu irmão Júlio Cézar pela compreensão e carinho.

Agradeço ao meu orientador Prof. Dr. Crispin Humberto Garcia Cruz por acreditar em meu trabalho, pela atenção, pela dedicação, pelos ensinamentos e por estar sempre presente.

À UNESP - São José do Rio Preto/SP e ao Programa de Pós-Graduação em Microbiologia, pela oportunidade de desenvolver esta pesquisa.

Agradeço aos técnicos de laboratório, Ginaldo, Luiz, Newton e principalmente à Tânia por sempre estar disposta a ajudar e sempre muito dedicada a resolver cada empecilho encontrado na pesquisa.

Aos professores Benício Alves de Abreu Filho e Eleni Gomes pelo auxílio na correção deste trabalho e participação na banca examinadora.

A todos os professores do curso de Pós- Graduação pelos ensinamentos necessários durante o desenvolvimento do mestrado.

Aos meus amigos Aline Zago de Grandi, Rafaella Martins, Luana Faria, Catharina Calochi, Gisele Bueno, Michele Coimbra, Vidiany Queiroz, Ana Maria, Ligia, Tayná Motta, Marcos Celli, Luís Virgílio e Leandro Jorge pelo companheirismo, pela compreensão e por sempre me fazer muito feliz.

A minha amiga Adriana da Silva pela ajuda no laboratório e por sua grande amizade e dedicação.

A CAPES pela bolsa de estudo.

Muito obrigada a todos. 


\section{SUMÁRIO}

LISTA DE TABELAS........................................................................... ix

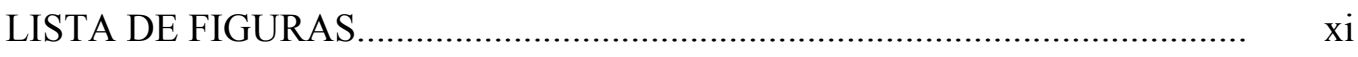

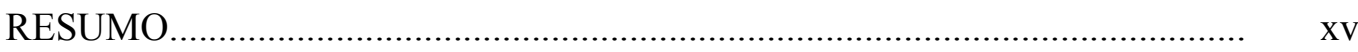

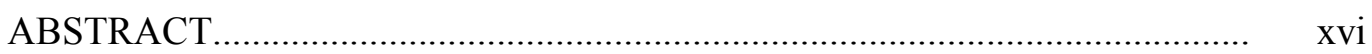

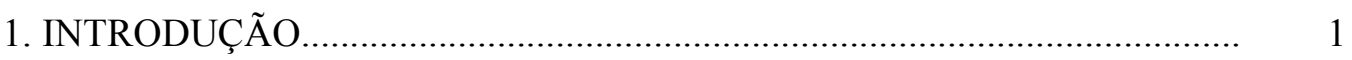

2. REVISÃO BIBLIOGRÁFICA................................................................. 2

2.1 SURFACTANTES..................................................................... 2

2.2 BIOSSURFACTANTES............................................................ 5

2.2.1 Aplicações dos biossurfactantes.................................................... 8

2.2.2 Microrganismos produtores de biossurfactantes............................. 13

2.3 Bacillus pumilus .............................................................................. 17

2.4 SUBSTRATOS.............................................................................. 19

2.4.1 - Glicose e sacarose ................................................................. 20

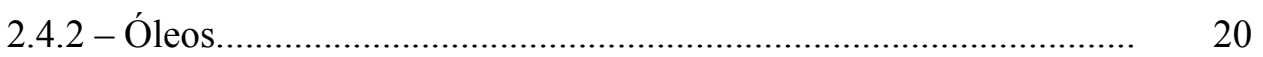

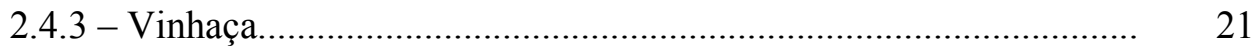

2.4.4 - Melaço.................................................................................... 22

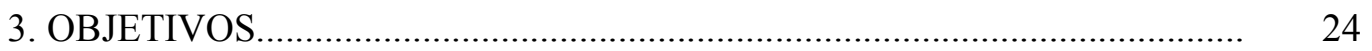

4. MATERIAL E MÉTODOS..................................................................... 25

4.1 MICRORGANISMO_............................................................................ 25

4.2 MEIOS DE CULTURA _.................................................................... 25

4.2.1 Meio de manutenção do microrganismo.......................................... 25

4.2.2 Meio mínimo ou basal.................................................................... 25

4.2.3 Meio de produção........................................................................... 25

4.3 PRODUÇÃO DE BIOSSURFACTANTE............................................... 26

4.3.1 Pré - fermentação............................................................................. 26

4.3.2 Fermentação............................................................................. 26

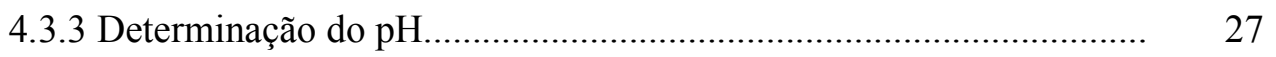

4.4 MÉTODOS ANALÍTICOS................................................................... 27

4.4.1 Determinação da presença de biossurfactante................................... 27 
4.4.2 Determinação da tensão superficial................................................... 28

4.4.3 Índice de emulsificação...................................................................... 28

4.4.4 Determinação da atividade emulsificante.......................................... 29

4.4.5 Determinação da concentração micelar crítica (CMC)...................... 29

4.4.6 Atividade antimicrobiana........................................................... 29

4.4.7 Separação do biossurfactante........................................................ 30

4.4.8 Construção da curva de calibração para determinação da massa 30 celular seca.

4.4.9 Determinação do crescimento microbiano......................................... 31

4.4.10 Potencial para biorremediação........................................................ 31

5. RESULTADOS E DISCUSSÃO................................................................. 33

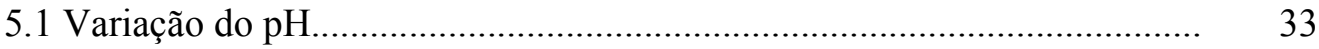

5.2 Tensão superficial............................................................................. 35

5.3 Índice de emulsificação.......................................................................... 39

5.4 Concentração Micelar Crítica (CMC)....................................................... 42

5.5 Separação do biossurfactante.................................................................. 45

5.6 Determinação da biomassa............................................................................ 49

5.7 Determinação da atividade emulsificante.................................................... 53

5.8 Determinação da atividade antimicrobiana................................................. 53

5.9 Avaliação do potencial para biorremediação............................................... 54

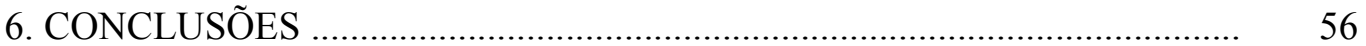

7. REFERÊNCIAS BIBLIOGRÁFICAS.................................................... 57 


\section{LISTA DE TABELAS}

Tabela 1 Tipo e origem microbiana dos biossurfactantes.

Tabela 2 Variação do $\mathrm{pH}$ para as diferentes concentrações de glicose utilizada pela bactéria Bacillus pumilus durante a produção de biossurfactante nos períodos de $24,48,72$ e 96 horas de incubação a $30^{\circ} \mathrm{C}$ e $200 \mathrm{rpm}$.

Tabela 3 Variação do pH para as diferentes concentrações de sacarose utilizada pela bactéria Bacillus pumilus durante a produção de biossurfactante nos períodos de 24, 48, 72 e 96 horas de incubação a $30^{\circ} \mathrm{C}$ e $200 \mathrm{rpm}$.

Tabela 4 Variação do pH para as diferentes concentrações de vinhaça utilizada pela bactéria Bacillus pumilus durante a produção de biossurfactante nos períodos de $24,48,72$ e 96 horas de incubação a $30^{\circ} \mathrm{C}$ e $200 \mathrm{rpm}$.

Tabela 5 Variação do $\mathrm{pH}$ para as diferentes concentrações de óelo residual de fritura utilizado pela bactéria Bacillus pumilus durante a produção de biossurfactante nos períodos de 24, 48, 72 e 96 horas de incubação a 30 ${ }^{\circ} \mathrm{C}$ e $200 \mathrm{rpm}$.

Tabela 6 Variação do pH para as diferentes concentrações de melaço utilizado pela bactéria Bacillus pumilus durante a produção de biossurfactante nos períodos de $24,48,72$ e 96 horas de incubação a $30^{\circ} \mathrm{C}$ e $200 \mathrm{rpm}$.

Tabela 7 Determinação do índice de emulsificação nos caldos livres de células obtidos durante 24, 48, 72 e 96 horas de fermentação com a bactéria Bacillus pumilus incubada a $30^{\circ} \mathrm{C}$ e $200 \mathrm{rpm}$ utilizando sacarose como substrato 
Tabela 8 Determinação do índice de emulsificação nos caldos livres de células obtidos durante 24, 48, 72 e 96 horas de fermentação com a bactéria Bacillus pumilus incubada a $30^{\circ} \mathrm{C}$ e $200 \mathrm{rpm}$ utilizando melaço como substrato

Tabela 9 Determinação da atividade emulsificante no sobrenadante livre de células a $620 \mathrm{~nm}$ nos períodos de fermentação de 24, 48, 72 e 96 horas nas diferentes concentrações de sacarose utilizadas por Bacillus pumilus incubada a $30^{\circ} \mathrm{C}$ e $200 \mathrm{rpm}$. 


\section{LISTA DE FIGURAS}

Figura 1 Esquema do comportamento do tensoativo entre as fases fluida e 4 superficial, em função da tensão superficial, indicando a c.m.c.

Figura 2 Um soforolipídio cíclico e um acíclico.

Figura 3 Surfactina produzida por Bacillus subtilis.

Figura 4 Emulsan, biossurfactante polimérico.

Figura 5 Frascos de Erlenmeyer incubados sob agitação de $200 \mathrm{rpm}$ a $30{ }^{\circ} \mathrm{C}$ durante 24, 48, 72 e 96 horas em meio de produção contendo a bactéria Bacillus pumilus.

Figura 6 Foto do processo de centrifugação (a); separação da célula do 28 sobrenadante (b).

Figura 7 Curva de calibração para determinação da biomassa.

Figura 8 Determinação da tensão superficial do sobrenadante livre de células obtido em diferentes concentrações de glicose durante 24, 48, 72, 96 horas de fermentação utilizando a bactéria Bacillus pumilus incubada a $30^{\circ} \mathrm{C}$ e $200 \mathrm{rpm}$.

Figura 9 Determinação da tensão superficial do sobrenadante livre de células obtido em diferentes concentrações de sacarose durante $24,48,72$, 96 horas de fermentação utilizando a bactéria Bacillus pumilus incubada a $30^{\circ} \mathrm{C}$ e $200 \mathrm{rpm}$.

Figura 10 Determinação da tensão superficial do sobrenadante livre de células 37 obtido em diferentes concentrações de vinhaça durante 24, 48, 72, 
96 horas de fermentação utilizando a bactéria Bacillus pumilus incubada a $30^{\circ} \mathrm{C}$ e $200 \mathrm{rpm}$.

Figura 11 Determinação da tensão superficial do sobrenadante livre de células 38 obtido em diferentes concentrações de óleo residual de fritura durante 24, 48, 72, 96 horas de fermentação utilizando a bactéria Bacillus pumilus incubada a $30^{\circ} \mathrm{C}$ e $200 \mathrm{rpm}$.

Figura 12 Determinação da tensão superficial do sobrenadante livre de células obtido em diferentes concentrações de melaço durante 24, 48, 72, 96 horas de fermentação utilizando a bactéria Bacillus pumilus incubada a $30^{\circ} \mathrm{C}$ e $200 \mathrm{rpm}$.

Figura 13 Emulsificação de tolueno adicionado ao caldo livre de células para a determinação do índice de emulsificação para o biossurfactante produzido com sacarose (a), e melaço (b).

Figura 14 Determinação da concentração micelar crítica (CMC) no sobrenadante livre de células quando foi utilizada glicose como substrato pela bactéria Bacillus pumilus durante 24, 48, 72 e 96 horas de fermentação incubada a $30^{\circ} \mathrm{C}$ e $200 \mathrm{rpm}$.

Figura 15 Determinação da concentração micelar crítica (CMC) no sobrenadante livre de células quando foi utilizada sacarose como substrato pela bactéria Bacillus pumilus durante 24, 48, 72 e 96 horas de fermentação incubada a $30^{\circ} \mathrm{C}$ e $200 \mathrm{rpm}$.

Figura 16 Determinação da concentração micelar crítica (CMC) no 44 sobrenadante livre de células quando foi utilizada vinhaça como substrato pela bactéria Bacillus pumilus durante 24, 48, 72 e 96 horas de fermentação incubada a $30^{\circ} \mathrm{C}$ e $200 \mathrm{rpm}$.

Figura 17 Determinação da concentração micelar crítica (CMC) no 45 
sobrenadante livre de células quando foi utilizado óleo residual de fritura como substrato pela bactéria Bacillus pumilus durante 24, 48, 72 e 96 horas de fermentação incubada a $30^{\circ} \mathrm{C}$ e $200 \mathrm{rpm}$.

Figura 18 Determinação da concentração micelar crítica (CMC) no sobrenadante livre de células quando foi utilizado melaço como substrato pela bactéria Bacillus pumilus durante 24, 48, 72 e 96 horas de fermentação incubada a $30^{\circ} \mathrm{C}$ e $200 \mathrm{rpm}$.

Figura 19 Relação da produção de biossurfactante $(\mathrm{g} / \mathrm{L})$ e da tensão superficial $(\mathrm{mN} / \mathrm{m})$ durante a fermentação de 24, 48, 72 e 96 horas, nas diferentes concentrações de glicose utilizadas por Bacillus pumilus incubada a $30^{\circ} \mathrm{C}$ e $200 \mathrm{rpm}$.

Figura 20 Relação da produção de biossurfactante e da tensão superficial durante a fermentação de 24, 48, 72 e 96 horas nas diferentes concentrações de sacarose utilizadas por Bacillus pumilus incubada a $30^{\circ} \mathrm{C}$ e $200 \mathrm{rpm}$.

Figura 21 Relação da produção de biossurfactante e da tensão superficial durante a fermentação de 24, 48, 72 e 96 horas nas diferentes concentrações de vinhaça utilizadas por Bacillus pumilus incubada a $30{ }^{\circ} \mathrm{C}$ e $200 \mathrm{rpm}$.

Figura 22 Relação da produção de biossurfactante e da tensão superficial durante a fermentação de 24, 48, 72 e 96 horas nas diferentes concentrações de óleo residual de fritura utilizadas por Bacillus pumilus incubada a $30{ }^{\circ} \mathrm{C}$ e $200 \mathrm{rpm}$.

Figura 23 Relação da produção de biossurfactante e da tensão superficial durante a fermentação de 24, 48, 72 e 96 horas nas diferentes concentrações de melaço utilizadas por Bacillus pumilus incubada a $30{ }^{\circ} \mathrm{C}$ e $200 \mathrm{rpm}$. 
Figura 24 Relação entre a produção de biossurfactante e massa celular seca $\quad 50$ durante os períodos de fermentação de 24, 48, 72 e 96 horas nas diferentes concentrações de glicose utilizadas por Bacillus pumilus incubada a $30^{\circ} \mathrm{C}$ e $200 \mathrm{rpm}$.

Figura 25 Relação entre a produção de biossurfactante e massa celular seca durante os períodos de fermentação de 24, 48, 72 e 96 horas nas diferentes concentrações de sacarose utilizadas por Bacillus pumilus incubada a $30^{\circ} \mathrm{C}$ e $200 \mathrm{rpm}$.

Figura 26 Relação entre a produção de biossurfactante e massa celular seca durante os períodos de fermentação de 24, 48, 72 e 96 horas nas diferentes concentrações de vinhaça utilizadas por Bacillus pumilus incubada a $30^{\circ} \mathrm{C}$ e $200 \mathrm{rpm}$.

Figura 27 Relação entre a produção de biossurfactante e massa celular seca durante os períodos de fermentação de 24, 48, 72 e 96 horas nas diferentes concentrações de óleo residual de fritura utilizadas por Bacillus pumilus incubada a $30^{\circ} \mathrm{C}$ e $200 \mathrm{rpm}$.

Figura 28 Relação entre a produção de biossurfactante e massa celular seca durante os períodos de fermentação de 24, 48, 72 e 96 horas nas diferentes concentrações de melaço utilizadas por Bacillus pumilus incubada a $30^{\circ} \mathrm{C}$ e $200 \mathrm{rpm}$.

Figura 29 Análise macroscópica do potencial de degradação do óleo residual 55 de fritura na presença do caldo fermentado livre de células proveniente da fermentação com sacarose na concentração de $4 \%$ em 96 horas pela bactéria Bacillus pumilus a $30^{\circ} \mathrm{C}$ em $200 \mathrm{rpm}$. 


\section{RESUMO}

Surfactantes são moléculas que por apresentarem porções hidrofílicas e hidrofóbicas são capazes de reduzir a tensão superficial de um meio fluido. Esta característica é importante para aplicações industriais fazendo destes tenso-ativos compostos de alto interesse. Compostos de origem microbiana que apresentam características surfactantes são denominados biossurfactantes e apresentam vantagens de serem produzidos a partir de substratos renováveis, serem biodegradáveis, apresentarem baixa toxicidade e especificidade química. O objetivo desse trabalho foi verificar a produção de biossurfactante pela bactéria Bacillus pumilus utilizando glicose, sacarose, vinhaça, óleo residual de fritura e melaço como substrato e avaliar o potencial para aplicação na biorremediação envolvendo óleo residual de fritura. $\mathrm{O}$ microrganismo foi mantido em meio ágar nutriente, para a produção de biossurfactante foi utilizado um meio mínimo basal composto por sais e óleo diesel acrescido de concentrações de 1 a $5 \%$ de glicose, sacarose, vinhaça, óleo residual de fritura e melaço, o $\mathrm{pH}$ foi ajustado a 7,0. A fermentação ocorreu em agitador orbital rotatório a $200 \mathrm{rpm}$ em $30{ }^{\circ} \mathrm{C}$, e foi verificada a produção de biossurfactante após 24, 48, 72 e 96h de fermentação. Foi verificada a variação do pH após cada período de fermentação. O caldo fermentado foi centrifugado a 7077 x g a $4{ }^{\circ} \mathrm{C}$ por 15 minutos. O crescimento celular foi determinado pela massa celular seca. A presença de biossurfactante foi verificada no caldo livre de células através da medição da tensão superficial, índice de emulsificação e concentração micelar crítica (CMC). O biossurfactante foi precipitado com etanol absoluto. A partir do melhor parâmetro de produção foi verificada a atividade emulsificante, atividade antimicrobiana e potencial para remoção do óleo residual de fritura da água e areia. A sacarose foi o melhor substrato, pois apresentou a maior produção de biossurfactante $(26,83 \mathrm{~g} / \mathrm{L})$ e maior redução da tensão superficial $(32 \mathrm{mN} / \mathrm{m})$ na concentração de 4\% em 96 horas. Em todos os substratos testados foi verificado produção de biossurfactante capaz de reduzir a tensão superficial e apresentar baixos valores de concentração micelar crítica (CMC). Somente o biossurfactante produzido utilizando sacarose e melaço foi capaz de formar emulsões estáveis. Não foi verificada atividade antimicrobiana nas condições testadas. $\mathrm{O}$ biossurfactante produzido pela bactéria Bacillus pumilus demonstrou ser potente para aplicação em desastres ecológicos envolvendo areia contaminada com óleo residual de fritura.

Palavras chave: biossurfactante, Bacillus pumilus, substratos renováveis, biorremediação. 


\section{ABSTRACT}

Surfactants are molecules that make portions of hydrophilic and hydrophobic are able to reduce the surface tension of a fluid medium. This feature is very important for industrial applications by making these surface-active compounds of high interest. Compounds of microbial origin that has characteristics surfactants are called biosurfactants and have advantages to be produced from renewable substrates, are biodegradable, they exhibit low toxicity and chemical specificity. The aim of the present study was to evaluate the biosurfactant production by Bacillus pumilus using glucose, sucrose, vinassa, waste frying oil and molasses as substrate and evaluate the potential for application in bioremediation involving residual oil frying. The bacterium organism was maintained on nutrient agar for biosurfactant production, it was used a minimal medium composed of salts and diesel oil increased by concentrations of 1 to $5 \%$ glucose, sucrose, vinassa, waste frying oil and molasses, $\mathrm{pH}$ was adjusted to 7,0 . Fermentation occurred in an orbital shaker rotating at $200 \mathrm{rpm}$ at $30^{\circ} \mathrm{C}$, and was evaluated the production of biosurfactant after 24, 48, 72 and 96 hours of fermentation. The change in $\mathrm{pH}$ was observed after each period of fermentation. The fermented broth was centrifuged at $7077 \mathrm{x}$ g at $4{ }^{\circ} \mathrm{C}$ for 15 minutes. The cell growth was determined by dry mass. The presence of biosurfactant was found in the cell-free broth by measuring the surface tension, emulsification index and critical micelle concentration $(\mathrm{CMC})$. The biosurfactant was precipitated with absolute ethanol. From the best measure of production was checked emulsifying activity, antimicrobial activity and potential for removal of residual oil from frying the water and sand. Sucrose was the best substrate, it showed the highest biosurfactant production $(26.83 \mathrm{~g} / \mathrm{L})$ and greater reduction of surface tension $(32 \mathrm{mN} / \mathrm{m})$ at a concentration of $4 \%$ in 96 hours. In all substrates was found biosurfactant production can reduce the surface tension and have low values of critical micelle concentration (CMC). Only the biosurfactant produced using molasses and sucrose and was able to form stable emulsions. There was no antimicrobial activity under the conditions tested. The biosurfactant produced by Bacillus pumilus was shown to be powerful for use in ecological disasters involving sand contaminated with residual oil frying.

Key-words: biosurfactant, Bacillus pumilus, renewable substrates, bioremediation. 


\section{1 - INTRODUÇÃO}

Os surfactantes constituem uma classe importante de compostos químicos amplamente utilizados em diversos setores industriais. São moléculas que apresentam porções hidrofóbicas e hidrofílicas, ou seja, são moléculas anfipáticas. Em função da presença destes grupos na mesma molécula, tendem a se distribuir nas interfaces entre as fases fluidas com diferentes graus de polaridade (óleo/água e água/óleo).

A formação de um filme molecular, ordenado nas interfaces, reduz a tensão interfacial e superficial, sendo responsável pelas propriedades únicas dos surfactantes, como detergência, emulsificação, lubrificação, capacidade espumante, capacidade molhante, solubilização, dispersão de fases e baixa toxicidade. Estas propriedades fazem os surfactantes adequados para uma ampla gama de aplicações industriais. A maior utilização se concentra na indústria de produtos de limpeza (sabões e detergentes), na indústria de petróleo e na indústria de cosméticos e produtos de higiene.

Alguns compostos de origem microbiana exibem propriedades surfactantes e são denominados biossurfactantes, os quais são subprodutos do metabolismo de bactérias, fungos e leveduras. São classificados de acordo com sua composição química e origem microbiana em glicolipídeos, lipopeptídeos, lipoproteínas, fosfolipídeos e ácidos graxos.

Uma grande variedade de biossurfactantes é produzida por microrganismos sendo que o tipo e a quantidade dependem do substrato utilizado como fonte de carbono e energia, e das condições de cultivo. Apresentam a vantagem de serem sintetizados a partir de substratos renováveis e possuírem grande diversidade química, possibilitando aplicações especificas para cada caso particular. Além disso, possuem características estruturais e propriedades físicas distintas, o que os torna comparáveis ou superiores aos surfactantes sintéticos em termos de eficiência, apresentando alta seletividade, baixa toxicidade, alta biodegradabilidade e maior compatibilidade com o ambiente. Estas vantagens fazem desses produtos biológicos moléculas alvo no que se refere à questões de gerenciamento ambiental e aplicações industriais. 


\section{REVISÃO BIBLIOGRÁFICA}

\subsection{SURFACTANTES}

Surfactantes são moléculas anfipáticas por possuírem uma porção hidrofóbica e uma porção hidrofílica. Os surfactantes sintéticos são classificados de acordo com a carga iônica que reside na parte polar da molécula, podendo ser aniônica ou catiônica, não iônica ou anfotérica, e a porção apolar é freqüentemente uma cadeia hidrocarbonada. Alguns exemplos de surfactantes iônicos utilizados comercialmente incluem ésteres sulfatados ou sulfatos de ácidos graxos (aniônicos) e sais de amônio quaternário (catiônico) (NITSCHKE; PASTORE, 2002).

Surfactantes catiônicos, aniônicos e não iônicos são usados principalmente para produtos de limpeza. Destes, os aniônicos e não iônicos são pouco absorvidos pelo solo. Os tenso-ativos catiônicos são utilizados para diminuir a permeabilidade de materiais em aqüíferos por sorção (CZAPLICKA; CHMIELARZ, 2009).

Estas moléculas tenso-ativas apresentam a capacidade de reduzir a tensão superficial e interfacial; aumentar a solubilidade e mobilidade de compostos hidrofóbicos ou compostos orgânicos insolúveis. Esta atividade de superfície faz dos surfactantes uma das mais importantes e versáteis classes de produtos químicos usados em uma variedade de aplicações (DELEU; PAQUOT, 2004). Apresentam propriedades tais como, detergência, emulsificação, lubrificação, capacidade espumante, solubilização e dispersão de fases. Essas características fazem desses compostos químicos produtos de grande utilidade em processos industriais, ocorrendo uma crescente demanda por surfactantes em indústrias farmacêuticas, de cosméticos, alimentos e na utilização em desastres ecológicos que contaminam o meio ambiente (BEDNARSKI et al., 2004).

A maior utilização dos surfactantes se concentra na indústria de produtos de limpeza (sabões e detergentes), indústria de petróleo e na indústria de cosméticos e produtos de higiene. Segundo Banat no ano 2000, a produção mundial de surfactantes excedeu três milhões de toneladas por ano, sendo a maioria utilizada como matéria-prima para fabricação de detergentes de uso doméstico (BANAT, 2000).

A eficácia dos surfactantes é determinada pela capacidade de reduzir a tensão superficial que é a medida de energia livre da superfície por unidade de área, necessária para trazer uma molécula do interior do líquido para a superfície. Devido à presença de 
surfactantes, menor energia é requerida para trazer uma molécula até a superfície reduzindo, assim, a tensão superficial. Outra determinação importante é a concentração micelar crítica (CMC) que é um dos índices mais utilizados para avaliar a atividade surfactante. Esta é definida como a solubilidade de um tenso-ativo na fase aquosa, ou seja, a concentração mínima de tenso-ativo necessária para atingir os valores mais baixos de tensão superficial e interfacial, a partir da qual se inicia a formação de agregados chamados de micelas (Figura 1). A tensão superficial entre a fase aquosa/oleosa muda muito pouco acima da concentração micelar crítica porque todas a moléculas de surfactantes adicionadas formam micelas (LIN, 1996).

A micelização é um processo comum a todos os surfactantes e é uma propriedade intrínseca e característica. A principal razão para a formação desses agregados é a diminuição da área de contato entre as cadeias hidrocarbônicas do surfactante e da água.

A formação de micelas pode resultar na solubilização de óleo e água, dando origem a uma emulsão. As propriedades únicas de micelas estão sendo exploradas em aplicações como a extração de proteínas do caldo de fermentação, remoção de íons metálicos e orgânicos a partir de solução aquosa e para aplicação ambiental. Após a CMC as micelas, ao contrário dos monômeros, ficam dispersas em toda a solução, não apresentando efeito sobre a tensão superficial da água.

Outro parâmetro freqüentemente utilizado para a avaliação do surfactante é o valor do balanço hidrofílico e lipofílico (HLB), pois essa relação afeta as propriedades físicoquímicas das moléculas. O valor de HLB é uma indicação de solubilidade no óleo ou na água da solução, quanto menor for esse valor mais solúvel será o óleo presente na solução. Geralmente, tenso-ativos com valores de HLB inferiores a seis são mais solúveis na fase oleosa, HLB com valores entre 10 e 18 têm a característica oposta (PARKINSON, 1985). 


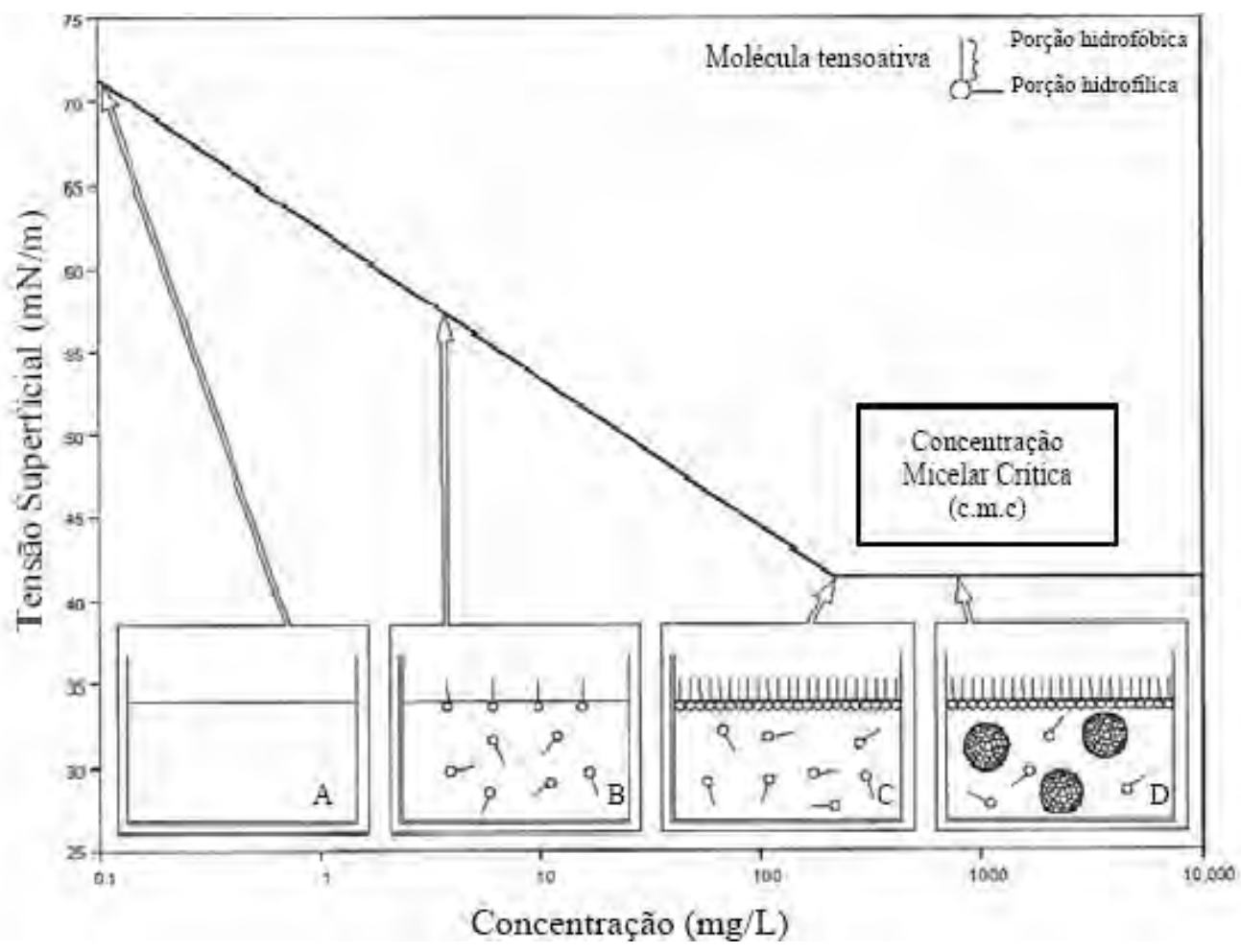

Figura 1. Esquema do comportamento do tensoativo entre as fases líquida e superficial, em função da tensão superficial, indicando a Concentração Micelar Crítica (CMC) (SANTOS, 2007).

O grande leque de aplicação dos surfactantes aumenta a sua demanda mundial crescendo também o interesse em uma produção mais barata, uma vez que, os surfactantes são produzidos a partir do petróleo e requerem síntese e várias etapas de purificação o que torna o processo de alto custo. Entretanto, vários compostos com propriedades tenso-ativas são sintetizados por organismos vivos, desde plantas (saponinas) até microrganismos (glicolipídios), sendo considerados surfactantes naturais.

Surfactante natural é considerado um tenso-ativo proveniente diretamente de uma fonte natural. A fonte pode ser de origem animal ou vegetal onde se encontram em abundância, o produto deve ser obtido por algum tipo de separação como procedimentos de extração, precipitação ou destilação. Atualmente não existem muitos tenso-ativos em uso que preencham esses requisitos. A Lecitina, obtida a partir de soja ou da gema de ovo, é provavelmente o melhor exemplo de um verdadeiro surfactante natural. Nos sistemas biológicos estas moléculas são usadas da mesma forma que são empregadas em sistemas técnicos, ou seja, para melhorar a solubilidade e como agentes emulsificantes e 
dispersantes. Porém, o alto custo de produção em escala industrial, e o fato delas estarem presentes normalmente em pequenas quantidades aumentariam o custo de produção. (HOMBERG, 2001).

Nos países industrializados $70-75 \%$ dos surfactantes consumidos são de origem petroquímica, enquanto que nos países em desenvolvimento os compostos de origem natural predominam. Nos países industrializados existe uma tendência desde 1999 para a substituição dos surfactantes sintéticos pelos naturais (BOGNOLO, 1999). Essa tendência é movida pela busca, cada vez mais crescente, de se obter um produto o mais compatível possível com o meio ambiente, e pela necessidade de substituição de moléculas não biodegradáveis que são poluentes à natureza. Desse ponto de vista ambiental é importante que todas as substâncias liberadas no meio ambiente sejam biodegradáveis para a preservação da flora e da fauna.

\subsection{BIOSSURFACTANTES}

Os compostos de origem microbiana que exibem propriedades surfactantes, isto é, diminuem a tensão superficial e possuem alta capacidade emulsificante, são denominados biossurfactantes (YAKIMOV et al., 1998), e consistem em subprodutos metabólicos de bactérias, fungos e leveduras.

A maioria dos biossurfactantes é produzida por bactérias, leveduras e fungos durante o crescimento em várias fontes de carbono (FIECHTER, 1992), porém, a razão exata destes microrganismos produzirem biossurfactantes não é sempre tão óbvia. Em microrganismos degradantes de petróleo os biossurfactantes são produzidos extracelularmente (BOUCHEZ et al., 1999; YAKIMOV et al., 1998). Neste caso, biossurfactantes tem a função de facilitar a captação do substrato pela célula microbiana e de degradação e emulsificação de hidrocarbonetos (KOCH et al., 1991). Outra possível explicação para a produção de biossurfactantes é que são produzidos como antibióticos para proteção das células contra ataques de outros microrganismos.

Estes compostos biotecnológicos (biossurfactantes) são produzidos extracelularmente ou pela membrana celular de bactérias ou leveduras cultivadas em meio contendo uma fração de uma fonte de carbono hidrofóbico (HOMMEL, 1990). São produzidos principalmente pelo crescimento aeróbio de microrganismos em meios aquosos a partir de carboidratos, hidrocarbonetos, óleos e gorduras ou misturas destes. 
Entretanto, a composição química e atividade emulsificante dos biossurfactantes dependem do microrganismo produtor e das condições de cultivo. Assim, na natureza a fonte de carbono e nitrogênio são limitações nutricionais e, parâmetros físicos como temperatura, aeração e $\mathrm{pH}$ influenciam no tipo de polímero produzido (CALVO et al., 2008). Essa característica é extremamente importante porque abre caminhos para futuras descobertas de novos compostos e para potencializar a produção destes.

$\mathrm{Na}$ natureza os biossurfactantes desempenham um papel fisiológico no aumento da disponibilidade de moléculas hidrofóbicas, estão envolvidos fornecendo substratos para o crescimento de outras bactérias, participam em processos fisiológicos de sinalização e diferenciação celular (KEAMS; LOSICK, 2003). Desempenham outras funções fisiológicas como emulsificação, solubilização de hidrocarbonetos ou compostos insolúveis em água, facilitando o crescimento de microrganismos nestes substratos. Os microrganismos podem utilizar surfactantes ligados à parede para regular as propriedades da superfície celular, visando aderir ou se desligar de um determinado local de acordo com sua necessidade para encontrar novos locais com maior disponibilidade de nutrientes ou se livrar de ambientes desfavoráveis, (ROSENBERG; RON, 1999).

As pesquisas com biossurfactantes são direcionadas para estudar as propriedades e comportamento da molécula em fase aquosa (HELVACI et al., 2004; ÖZDEMIR; MALAYOUGLU, 2004; ÖZDEMIR et al., 2004a). Comumente apresentam as vantagens de biodegradabilidade, baixo índice de toxicidade, resistência ao $\mathrm{pH}$ e mudanças de temperatura e biocompatibilidade em comparação com surfactantes produzidos sinteticamente (ROSENBERG; RON , 1999). Outra vantagem reside no fato de serem compostos não derivados de petróleo, fator importante à medida que os preços do petróleo não são estáveis. A possibilidade de modificação da estrutura química e das propriedades físicas dos biossurfactantes através de manipulações genéticas, biológicas ou químicas permite o desenvolvimento de produtos para necessidades específicas. (NITSCHKE; PASTORE, 2002). Além destas vantagens estas moléculas podem ser sintetizadas a partir de substratos renováveis o que reduziria um dos fatores limitantes, o custo de produção. E possuem grande diversidade química, possibilitando aplicações específicas para cada caso particular.

Como desvantagem os biossurfactantes apresentam a dificuldade na seleção de um resíduo com composição adequada de nutrientes que permita o crescimento celular e o acúmulo do produto de interesse, sendo necessária a padronização do processo 
biotecnológico. Além disso, alguns fatores interferem na produção: apresentam baixos rendimentos, necessidade de grande investimento de capital, necessidade de um sistema estéril, alguns problemas no controle do processo, na recuperação e purificação do produto e análise química devido a sua complexidade (CALVO et al., 2008).

Estas moléculas incluem uma grande variedade de compostos, glicolipídios, lipoproteínas, polipeptídios complexos, fosfolipídios, ácidos graxos e lipídios neutros (NITSCHKE; PASTORE, 2002), que são classificados de acordo com a composição química e origem microbiana (ROSENBERG; RON 1999). A maioria dos biossurfactantes são neutros ou aniônicos variando desde pequenos ácidos graxos até grandes polímeros. A parte hidrofóbica é caracterizada por ácidos graxos de cadeia longa. Esta porção pode ser saturada, insaturada ou de ácidos graxos hidroxilados (NGUYEN et al., 2008), enquanto que a porção hidrofílica pode ser um carboidrato, um aminoácido, um peptídeo cíclico, um fosfato, um ácido carboxílico ou um álcool.

Glicolipídios são geralmente ácidos graxos hidroxilados ligados com açúcar via ligação glicosídica, soforolipídios e ramnolipídios são exemplos bem conhecidos que são produzidos por Pseudomonas e Candida (WEBER et al., 1990). A Figura 2 mostra um soforolipídio cíclico e um acíclico. Ramnolípidios podem ser eficientemente produzidos durante o crescimento em hidrocarbonetos ou carboidratos como uma única fonte de carbono, (HOLMBERG 2001).

A produção de ramnolipídios foi verificada por Golveia e colaboradores (2003), utilizando bactérias isoladas de poços de petróleo que demonstraram a capacidade de degradação deste, sendo de grande importância para a biorremediação em áreas afetadas por derramamento de petróleo.
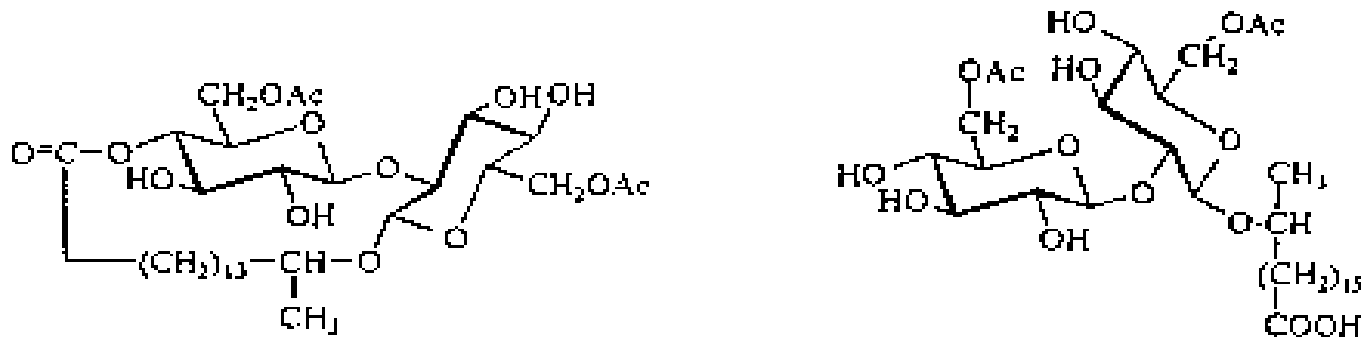

Figura. 2. Um soforolipídio cíclico e um acíclico (HOLMBERG 2001).

Os lipopeptídeos geralmente são cíclicos e estão compostos por um ácido hidroxilado e uma cadeia peptídica curta. Um exemplo extensivamente estudado é a surfactina (Figura 3) que é produzida pela bactéria Bacillus subtilis, com propriedades 
altamente eficientes para aplicações industriais. Esta é usada para uma variedade de aplicações farmacológicas (VOLLENBROICH 1997).

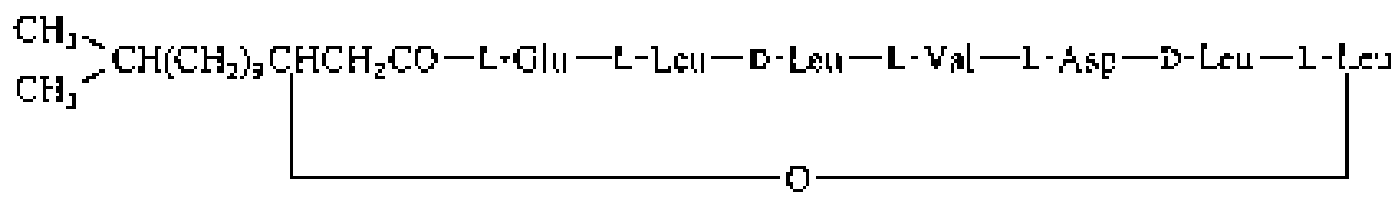

Figura 3. Surfactina produzida por Bacillus subtilis (HOLMBERG, 2001).

Os biossurfactantes poliméricos são constituídos por diversos grupos químicos diferentes como, por exemplo, o emulsan, no qual ácidos graxos estão ligados a um esqueleto de heteropolissacarídeos (Figura 4) ou o liposan de Candida lipolytica, constituído por carboidratos e proteínas. Os biossurfactantes poliméricos são promissores para a produção de fármacos, cosméticos e alimentos, porque são capazes de formar emulsões estáveis que são difíceis de romper.

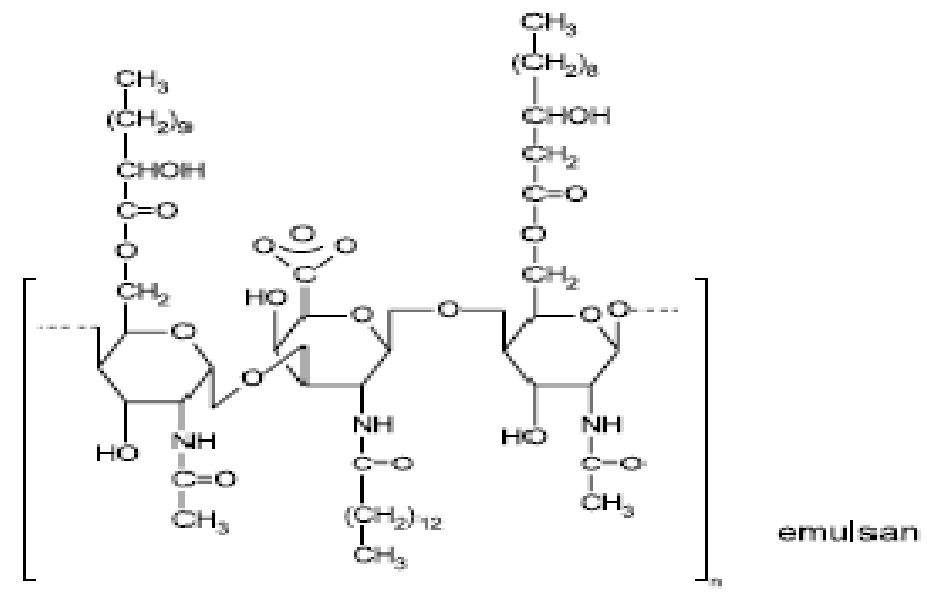

Figura 4. Emulsan, biossurfactante polimérico. (NITSCHKE; PASTORE, 2002).

\subsubsection{Aplicações dos biossurfactantes}

Atualmente existe uma grande preocupação e maior conscientização da sociedade em relação ao meio ambiente e a qualidade deste, além de uma crescente demanda no gerenciamento das questões ambientais. Dessa forma avanços significativos são observados nos estudos que visam a recuperação ambiental. Os biossurfactantes, pelo fato 
de ter uma origem biológica e apresentarem melhor biocompatibilidade e biodegradabilidade, têm um grande número de aplicações potenciais para este tipo de tenso-ativos.

As propriedades físico-químicas, características dos biossurfactantes, fazem que a indústria petrolífera seja o maior mercado pois seriam utilizados na produção de petróleo ou incorporados em formulações de óleos lubrificantes (VAN DIKI et al., 1991). Outras aplicações incluem biorremediação e dispersão no derramamento de óleos, remoção e mobilização de resíduos de óleo em tanques de estocagem e a recuperação melhorada de petróleo.

O uso de atividade biológica para eliminação de poluentes ambientais é descrito como biorremediação, e envolve o melhoramento do processo de biodegradação dos contaminantes (SINGH et al., 2007). A biorremediação pode ser considerada como uma nova tecnologia para tratar locais contaminados mediante o uso de agentes biológicos capazes de modificar ou decompor poluentes alvos. Essa tecnologia é baseada em processos nos quais ocorrem reações bioquímicas mediadas por microrganismos.

As estratégias de biorremediação incluem: a utilização de microrganismos autóctones, ou seja, do próprio local, sem qualquer interferência de tecnologias ativas de remediação (biorremediação intrínseca ou natural), isto evita custo e distúrbios ambientais associados com movimentos de solos e águas para outros locais destinados ao tratamento; a adição de agentes estimulantes como nutrientes, oxigênio e biossurfactantes (bioestimulação) e a inoculação de consórcios microbianos (BENTO et al., 2003). O benefício desses processos é a mineralização do poluente, isto é, a transformação em gás carbônico, água e biomassa. O mecanismo de ação e a eficiência do surfactante na biodegradação do poluente mudarão dependendo da espécie de microrganismo presente.

Existem algumas limitações naturais comuns à biodegradação de poluentes, como altos níveis de concentração de agentes poluidores, falta de oxigênio, $\mathrm{pH}$, temperatura e baixa umidade desfavorável e falta de nutrientes minerais. Uma vez que, estas condições são corrigidas, a distribuição natural de microrganismos permite um crescimento espontâneo apropriado favorecendo, assim, uma melhora na remediação do contaminante.

O princípio básico de métodos para remoção consiste na mobilização e / ou a solubilização de hidrocarbonetos através da redução da tensão superficial nas interfaces das fases orgânica - solo e orgânica - água (CHU; CHAN, 2003). Em geral, a remediação por surfactantes no solo é feita removendo moléculas orgânicas adsorvidas e 
aprisionadas nos poros, seguida pelo encapsulamento dentro de micelas formadas em concentração maior que a concentração micelar critica (CMC).

No trabalho realizado por Bicca e colaboradores, (1999), foi avaliada a produção de biossurfactantes por cinco cepas de Rhodococcus isoladas de sítios de prospecção de óleo. A medição da tensão superficial e o índice de emulsificação foram usados para quantificar a produção de biossurfactante. Investigou-se também a influência de condições ambientais: $\mathrm{pH}$, temperatura, composição do meio, e o tipo de fonte de carbono no crescimento celular e na produção. Este trabalho indicou a possibilidade do uso de uma das cepas diretamente em derrames de óleo no ambiente ou na produção biotecnológica de biossurfactantes (BICCA et al., 1999).

A estrutura química dos poluentes orgânicos tem uma profunda influência na capacidade dos microrganismos metabolizarem determinadas moléculas especialmente com respeito às taxas e extensão da biodegradação. A solubilidade de hidrocarbonetos depende de muitos fatores: o tipo e a quantidade de surfactante e a taxa de contaminação.

Estudos sobre a remoção de hidrocarbonetos por surfactantes indicam o efeito de vários fatores, como por exemplo, precipitação e adsorção do surfactante no terreno, solubilização do contaminante e condutividade hidráulica do solo (DWARAKANATH et al., 1999), influência da textura e qualidade do solo sobre a remoção de contaminantes orgânicos (LEE et al., 2002). Indicam também influência do pH e concentrações de amônia na atividade de biossurfactantes na biorremediação (WHANG et al., 2009).

A estrutura do solo determina a capacidade de transferência da água e nutrientes para as áreas bioativas, conseqüentemente, a presença de biossurfactantes no solo pode produzir um efeito positivo na forma de estimular a dissolução, solubilização, ou mesmo de emulsificação dos hidrocarbonetos (CALVO et al., 2008).

Khalladi e colaboradores (2009) estudaram a remoção de óleo diesel de solo em coluna de vidro por um processo de lavagem contínuo, com os objetivos de remover o óleo contaminante usando uma solução de água com surfactante aniônico para determinar o modelo cinético do diesel no solo. Os resultados demonstraram que a presença de minerais no solo melhorou a atividade do surfactante na superfície, demonstrando, assim, o efeito da composição do solo sobre a eficiência do surfactante durante a reabilitação deste.

A água disponível para o crescimento microbiano e o metabolismo também é fator limitante no processo da biodegradação do hidrocarboneto. A diminuição no teor de umidade resulta em uma diminuição na atividade microbiana, (AYOTAMUNO et al., 
2006). Geralmente, ocorre ótima atividade quando a umidade do solo é de $50-80 \%$ de saturação (CALVO et al., 2008).

Entre as aplicações industriais, uma que se destaca é a recuperação melhorada do petróleo (MEOR), que consiste em uma tecnologia de recuperação terciária do petróleo que utiliza microrganismos ou produtos do seu metabolismo para a recuperação do óleo residual. Os microrganismos produzem polímeros e surfactantes que reduzem a tensão superficial óleo-rocha, reduzindo as forças capilares que impedem a movimentação do óleo através dos poros da rocha. Os biossurfactantes também auxiliam na emulsificação e na quebra dos filmes de óleo nas rochas (NEVES et al., 2004).

A utilização de biossurfactantes em MEOR envolve várias estratégias, como a injeção de microrganismos produtores no reservatório e subseqüente propagação in situ, ou a injeção de nutrientes no reservatório, estimulando o crescimento dos microrganismos produtores de biossurfactantes (NEVES et al., 2004).

$\mathrm{Na}$ indústria alimentícia, a emulsificação tem papel importante na formação da consistência e textura, bem como, na dispersão de fases e na solubilização de aromas. Nos alimentos, além do seu papel óbvio, como agentes que diminuem a tensão superficial e interfacial, os surfactantes promovem a formação e estabilização de emulsões. Porém podem ter outras funções: para controlar a aglomeração de gordura, estabilizar sistemas gasosos, melhorar a textura e o período de vida útil de produtos contendo amido, modificar as propriedades reológicas da farinha de trigo e das massas, melhorar a textura de produtos à base de gordura, neste contexto se enquadram em processos de panificação e produtos derivados de carne (NITSCHKE; PASTORE, 2002).

Outra aplicação para biossurfactantes é na indústria de laticínios onde retardam a colonização de Streptococcus thermophilus responsável pelo cheiro ou gosto ruim durante a pasteurização (BANAT et al., 2000). Alguns biossurfactantes já estão sendo utilizados comercialmente, por exemplo, o bioemulsificante produzido por Candida utilis que tem sido usado em molhos industriais para saladas (NITSCHKE; PASTORE, 2002).

Uma abordagem interessante para a indústria alimentar é o uso de seus subprodutos ou resíduos como substratos para a produção de biossurfactantes. Uma vez que, esses resíduos geralmente contêm altos níveis de carboidratos ou lipídios, necessários para apoiar o crescimento microbiano e a síntese dessas moléculas. Além disso, os altos custos de tratamento e eliminação desses resíduos são significativos às indústrias que freqüentemente estão buscando alternativas para reduzir, reutilizar, reciclar e valorizar os 
seus resíduos. Na literatura, apenas alguns tipos de surfactantes produzidos a partir de resíduos têm sido publicados. As principais fontes são oleosas, resíduos de indústrias lácticas e resíduos ricos em carboidratos. Em 2009, Daverey e Pakshirajan, potencializaram a produção de soforolipídio pela levedura Candida bombicola utilizando meios de baixo custo.

Muitos biossurfactantes são descritos na literatura como agentes antimicrobianos como, por exemplo, surfactina que é produzida pela bactéria Bacillus subtilis, (FERNANDES et al., 2007), esta também possui várias aplicações terapêuticas como a inibição da formação de coágulos; formação de canais iônicos em membranas, atividade antitumoral (ARIMA et al., 1968; PEYPOUX et al., 1999).

Os biossurfactantes soforolipídeos (SLPs) apresentam atividade anticancerígena. A surfactina possui atividade bactericida, fungicida, antiviral, agente antitumoral, atua como inibidor da formação de coágulos fibrinosos, antimicoplasmático, veículo para administração de drogas via pulmonar e é capaz de inibir a formação de biofilmes de algumas bactérias (BARROS et al., 2007). A utilização de biossurfactantes no controle de biofilmes, reduzindo a aderência em combinação com antibióticos pode representar uma estratégia antimicrobiana, uma vez que os antibióticos são em geral menos eficazes contra os biofilmes (IRIE et al., 2005).

$\mathrm{Na}$ agricultura os biossurfactantes são usados especialmente em formulações de herbicidas e pesticidas, devido aos compostos ativos serem geralmente hidrofóbicos fazendo-se necessário o uso de agentes emulsificantes para dispersá-los em soluções aquosas. Também são usados no controle biológico. Além destes, tem sido realizados estudos a fim de avaliar o potencial de remoção de metais pesados do solo usando biossurfactantes (ASFÇE et al., 2008; CZAPLICKA; CHMIELARZ, 2009).

Em um trabalho realizado por Zouboulis e colaboradores (2003), foi avaliado o potencial de remoção de íons de zinco e cromo de soluções aquosas por biossurfactante em comparação com outro tenso-ativo quimicamente similar, verificou-se que melhor flotabilidade dos metais foi obtida quando foi usado biossurfactante.

Em 2007, Asha e colaboradores realizaram um estudo que demonstrou que a tecnologia do uso de biossurfactante pode ser um método não destrutivo e eficaz para biorremediação de solo contaminado com cádmio e chumbo. 
Devido à compatibilidade com a pele os biossurfactantes podem ser usados na indústria de cosméticos e produtos de higiene, onde a maioria tem ação umectante, ação espumante, solubilizadores e mediadores de ação enzimática.

Outros campos de utilização dos biossurfactantes incluem a indústria de papel, têxtil, cerâmica e na fabricação de extintores de incêndio (NITSCHKE; PASTORE, 2002).

\subsubsection{Microrganismos produtores de biossurfactantes}

Os microrganismos produzem uma extensa variedade de materiais tenso-ativos com diferentes estruturas moleculares (Tabela 1). Dentre os fatores que interferem na produção e no nível de expressão estão, além da genética do microrganismo, as condições ambientais e a natureza do substrato (RAHMAM et al., 2002).

Segundo Georgiou e colaboradores (1992), uma grande variedade de microrganismos produz biossurfactantes, sendo que o tipo, a quantidade e a qualidade são influenciados pela natureza do substrato, concentração dos íons no meio de cultura, além das condições de cultivo.

Em vários casos, foi demonstrado que a produção de emulsificantes é induzida por moléculas envolvidas em sinais de "quorum sensing". Esta regulação característica parece ser geral, e provavelmente aplica-se a produção de emulsificantes de altos e baixos pesos moleculares. Como todos os casos a produção é concomitante com o aumento da densidade celular e do surgimento da fase estacionária de crescimento (ROSEMBERG; RON, 1999; BRINT; OHMAN, 1995; VAN DELDEN et al., 1998). 
TABELA 1. Tipo e origem microbiana dos biossurfactantes (MULLIGAN, 2005).

\begin{tabular}{|c|c|}
\hline Tipo de biossurfactante & Microrganismos \\
\hline Lipídios trealose & $\begin{array}{c}\text { Arthrobacter paraffineus, } \\
\text { Corynebacterium spp., } \\
\text { Mycobacterium spp., } \\
\text { Rhodococus ervthropolis, Nocardia sp. }\end{array}$ \\
\hline Ramnolipídios & $\begin{array}{c}\text { Pseudomonas aeruginosa, } \\
\text { Pseudomonas SP., Serratia rubidea }\end{array}$ \\
\hline Soforolipídios & $\begin{array}{l}\text { Candida apicola, Candida bombicola, } \\
\text { Candida lipolytica, Candida bogoriensis }\end{array}$ \\
\hline Glicolipídios & $\begin{array}{c}\text { Alcanivorax borkumensis, } \\
\text { Arthrobacter sp., Corynebacterium sp., } \\
\text { R. erythropolis, Serratia marcescens, } \\
\text { Tsukamurella } \mathrm{sp} .\end{array}$ \\
\hline Lipídios celobiose & Ustilago maydis \\
\hline Lipídios poliol & $\begin{array}{l}\text { Rhodotorula glutinus, } \\
\text { Rhodotorula graminus }\end{array}$ \\
\hline Diglicosil diglicerídios & Lactobacillus fermentii \\
\hline Lipopolissacarídios & $\begin{array}{l}\text { Acinetobacter calcoaceticus (RAG1) } \\
\text { Pseudomonas sp., Candida lipolytica }\end{array}$ \\
\hline Artrofactina & Arthrobacter sp. \\
\hline Liquenisina $\mathrm{A}$ e $\mathrm{B}$ & Bacillus licheniformis \\
\hline Surfactina & Bacillus subtilis, Bacillus pumilus \\
\hline Viscosina & Pseudomonas fluorescens \\
\hline Ornitina, peptídiolisina & $\begin{array}{l}\text { Thiobacillus thiooxidans, } \\
\text { Streptomyces sioyaensis, } \\
\text { Gluconobacter cerinus }\end{array}$ \\
\hline Fosfolipídios & Acinetobacter sp. \\
\hline Sulfonilipídios & $\begin{array}{c}\text { T. thiooxidans, Corynebacterium } \\
\text { alkanolyticum }\end{array}$ \\
\hline $\begin{array}{l}\text { Ácidos graxos } \\
\text { (ácidos corinomicólicos, ácidos } \\
\text { espiculispórico, etc. }\end{array}$ & $\begin{array}{l}\text { Capnocytophaga sp., } \\
\text { Penicillium spiculisporum, } \\
\text { Corynebacterium lepus, } \\
\text { Arthrobacter paraffineus, } \\
\text { Talaramyces trachyspermus, } \\
\text { Nocardia erythropolis }\end{array}$ \\
\hline Alasana & Acinetobacter radioresistens \\
\hline Estreptofactina & Streptomyces tendae \\
\hline Surfactante particulado (PM) & Pseudomonas marginalis \\
\hline Biosur PM & Pseudomonas maltophilla \\
\hline
\end{tabular}


Pseudomonas aeruginosa e P. putida isoladas do meio ambiente (em geral águas de esgoto), comprovaram em laboratório a produção de enzimas lipolíticas (lipases) e substâncias biossurfactantes. Um dos glicolipídios mais estudados é o ramnolipídio, produzido por várias espécies de Pseudomonas. Este ramnolipídio tem sido aplicado em várias indústrias e processos de biorremediação devido a sua alta atividade emulsificante e sua atuação na redução da tensão superficial (até $30 \mathrm{mN} / \mathrm{m}$ ) (WEI et al., 2005).

Chakrabarty (1985) mostrou que um emulsificante produzido por Pseudomonas aeruginosa SB30 pode dispersar petróleo em finas gotículas o que facilita a biodegradação.

Em 2009, Pomsunthorntawee e colaboradores avaliaram a capacidade de produção de biossurfactante por Pseudomonas aeruginosa SP4, que foi isolada a partir de solo contaminado com petróleo na Tailândia. Os resultados demonstraram potencial para produção em grande escala.

Desde 1998, uma nova classe de glicolipídios produzidos pelo microrganismo Alcanivorax borkumensis foi descrita (ABRAHAM, 1998). Estes consistem de um glicolipídio aniônico com uma oxiacila tetramérica na cadeia lateral.

O gênero Rhodococcus é capaz de transformar, biodegradar ou utilizar como fontes de carbono vários compostos hidrofóbicos (hidrocarbonetos, esteróides, lignina, etc.), produzindo glicolipídios contendo trealose como carboidrato. Seu biossurfactante tem a capacidade de reduzir a tensão superficial e interfacial a níveis observados nos surfactantes sintéticos, além de possuir baixa CMC. Cepas de Rhodococcus ruber e Rodhococcus erythropolis são capazes de produzir essa biomolécula em escala comercial para a utilização no controle da poluição (BICCA et al., 1999).

Um exemplo de biossurfactante lipoproteico é a surfactina, um biossurfactante produzido por Bacillus subtillis e é um dos produtos mais conhecidos entre os tipos de biossurfactantes produzidos por microrganismos com aplicação comercial (YEH et al., 2005). Na Índia em 2007, Joshi e colaboradores realizaram a produção de biossurfactantes com Bacillus subtilis 20B isolado de alimentos fermentados e foi verificada e discutida uma possível aplicação do biossurfactante em recuperação de óleos.

Em 2003, Queiroga e colaboradores observaram a redução da tensão superficial de $53 \mathrm{mN} / \mathrm{m}$ para $25,7 \mathrm{mN} / \mathrm{m}$ em função da produção de biossurfactantes produzido por Bacillus subtilis na presença de petróleo como substrato. Esta bactéria também apresenta grande produção de surfactina utilizando água residuária de mandioca como substrato, o biopolímero produzido mantém emulsões estáveis com vários hidrocarbonetos. Este 
substrato provou ser eficiente para a biossíntese e acúmulo do tenso-ativo (NITSCHKE; PASTORE, 2006).

Em 2008, Lee e colaboradores isolaram Klebsiella spp. produtora de um lipopeptídio a partir de resíduos de óleo de soja. Este biossurfactante apresenta melhor estabilidade e melhor emulsificação quando comparado a um surfactante sintético.

Chromobacterium violaceum pertence ao grupo das bactérias Gram-negativas, facultativa anaeróbica, esta bactéria destaca-se por apresentar grande potencial para diversas aplicações biotecnológicas, entre elas a produção de biossurfactante utilizando substratos alternativos como óleo de pequi (BARBOSA; PAZ, 2007).

A bactéria Thiobacillus thiooxidans produz biossurfactantes fosfolipídios, enquanto as espécies Acinetobacter sintetizam complexos lipopolissacarídeos.

Dentre as leveduras, as espécies do gênero Candida têm sido largamente utilizadas com sucesso para a produção de biossurfactantes desse tipo, dentre elas a Candida bombicola tem-se destacado como produtora. Em um estudo realizado por Daverey e Pakshirajan (2009), utilizando resíduos de baixo custo como melaço e óleos, foi obtido um biossurfactante soforolipídio por esta espécie.

Bednarski e colaboradores, (2004) induziram a produção de glicolipídios por Candida antarctica e Candida apicola a partir de resíduos do refino de óleo e o biossurfactante produzido foi capaz de reduzir consideravelmente a tensão superficial do meio.

Candida catenulata é um microrganismo potencial para biorremediação de solos contaminados com óleo e resíduos alimentares através de processos de compostagem, sugerindo que esse microrganismo é produtor de algum agente tenso-ativo (JOO et al., 2008).

O biossurfactante produzido por Candida antarctica utilizando n- alcanos como substratos demonstrou ser eficiente porque influenciou positivamente a emulsificação e biodegradação destes compostos (HUA et al., 2003).

O biossurfactante (glicolipídio aniônico) produzido por Candida sphaerica UCP0995, foi capaz de reduzir a tensão superficial, manter estabilidade em relação a pH e apresentar alta atividade emulsificante (SOBRINHO et al., 2008).

Aragão e colaboradores (2007) estudaram duas espécies de leveduras, Pichia membranaefaciens e Pichia anomala, que foram cultivadas em meio mineral contendo $2 \%$ 
de glicerol e obtiveram a produção de biossurfactantes, ocorrendo o mesmo quando gasolina e querosene foram adicionados como substratos.

A espécie Pseudozyma fusiformata produz um biossurfactante termoestável de baixo peso molecular com propriedade fungicida (LANG, 2002). Em um trabalho realizado por Fukuoka e colaboradores (2008) uma levedura do gênero Pseudozyma apresentou potencial para produzir um glicolipídio.

Biossurfactantes produzidos por microrganismos marinhos têm recebido atenção especial para a biorremediação do oceano. Em 2005 Maneerat descreveu que os biossurfactantes provenientes desses microrganismos são agentes promissores na biorremediação de hidrocarbonetos, principalmente petróleo.

Recentemente foi observada a produção de um biossurfactante caracterizado como glicoproteína de um fungo marinho Aspergillus ustus isolado da costa da Índia, este tensoativo apresentou amplo espectro de atividade antimicrobiana, assim como alto potencial para aplicação ambiental. (KIRAN et al., 2009). Logo em 2010 Kiran e colaboradores caracterizaram um novo biossurfactante lipopeptídico produzido por uma actinobactéria marinha chamada Brevibacterium aureum em estado sólido utilizando resíduos agroindustriais, este biossurfactante também foi sugerido por estes autores para recuperação de ambientes marinhos.

\subsection{Bacillus pumilus}

Bacillus pumilus é uma bactéria Gram-positiva aeróbia, formadora de esporos. A ocorrência desse microrganismo se dá em solo, água, ar e em decomposição de tecidos vegetais, são freqüentemente encontrados em simbiose no desenvolvimento radicular de plantas. Esta bactéria é produtora de varias moléculas, como biossurfactantes, proteases, lignocelulases e uma variedade de toxinas e antibióticos.

De acordo com Peypoux e colaboradores (1999), B. pumilus produz um lipopeptídeo da família da surfactina, chamado de pumilacidina. Em 2000, Banat e colaboradores reportaram somente B. subtilis e B. pumilus como produtores de surfactina.

Bueno (2008) isolou vários microrganismos de amostras de solo contaminado com hidrocarbonetos para avaliar a produção de biossurfactantes. Nesta pesquisa o microrganismo que melhor produziu foi a bactéria identificada como Bacillus pumilus 
utilizando como fonte de carbono baixas concentrações de sacarose, adicionado de óleo diesel como indutor.

Em um trabalho realizado por Bento e colaboradores (2003), foram caracterizados biossurfactantes produzidos por populações microbianas de solos dos Estados Unidos e da China contaminados com óleo diesel. Dentre as bactérias produtoras B. pumilus foi a bactéria que reduziu significativamente a tensão superficial, e aumentou a emulsificação em $59 \%$.

Biossurfactantes produzidos por Bacillus pumilus em amostra isolada a partir de resíduos de óleo, (CALVO et al., 2008), demonstraram ser esta bactéria um agente promissor para aplicação ambiental.

B. pumilus, apresentou efeito fungicida impedindo a germinação dos esporos de certos fungos, constituindo uma barreira física entre a planta e os esporos fúngicos. Neste contexto, esse microrganismo é estudado para o biocontrole de doenças de plantas, os lipopeptídeos produzidos por Bacillus apresentam uma vasta gama de potenciais fitopatógenos, incluindo bactérias, fungos e oomycetes. Estudos também apontam que essas moléculas apresentam um papel fundamental no processo de interação entre as espécies de Bacillus e a planta hospedeira estimulando mecanismos de defesa (ORGENA; JACQUES, 2007). Esse microrganismo é potencialmente grande produtor de lignocelulases, (POORNA; PREMA, 2006). É uma das espécies mais utilizadas na indústria para a produção de proteases que são utilizadas na coagulação do leite de soja (AOYAMA et al., 2000) e na limpeza de membrana de filtragem.

Bacillus pumilus também é uma bactéria relatada como produtora de toxinas, experimentalmente associadas à clindomicina (BROPHY; KNOOP, 1982). Hoult e Tuxford (1991) realizaram estudos da produção de toxinas de duas amostras de Bacillus pumilus (M11, M38) em comparação com outras bactérias, avaliaram efeito citopático em células "Vero" e atividade hemolítica.

Em um trabalho realizado por Cho e colaboradores (2009) Bacillus pumilus apresentou atividade antimicrobiana contra Micrococcus luteus e Staphylococcus aureus. $\mathrm{O}$ antibiótico produzido foi designado bacitracina. Este estudo revelou que B. pumilus pode ser proposto como uma boa linhagem para a produção deste composto que é exclusivamente ativo contra bactérias Gram-positivas. Esta bactéria também apresenta atividade antifúngica contra Aspergillus flavus e Aspergillus parasiticus, dois 
contaminantes comuns de alimentos a base de soja, o composto que foi antifúngico foi semelhante ao lipopeptídio iturina.

Em um trabalho realizado por Aly e colaboradores (2008) o microrganismo $B$. pumilus demonstrou ser um agente promissor no controle probiótico de Aeromonas hydrophila. Os resultados deste trabalho demonstraram que a utilização de probióticos é uma abordagem útil no reforço da resistência contra infecções.

\subsection{SUBSTRATOS}

A biotecnologia facilita a síntese de determinados produtos em favor da natureza, é um ramo muito amplo da tecnologia que se ocupa da transformação ou tratamento de materiais de origem biológica. A tendência atual é de incluir no termo biotecnologia, em seu aspecto mais essencial, a microbiologia industrial, que trata do aproveitamento dos microrganismos como agentes de degradação e síntese. As novas técnicas passam a estimular as células para que usem substratos alternativos (MULLIGAN, 2005).

Os biossurfactantes são com freqüência produzidos por bactérias capazes de crescerem em hidrocarbonetos que estimulam o crescimento e aceleram a biorremediação. Esses microrganismos são ubíquos na natureza e são capazes de degradar os diversos tipos de hidrocarbonetos de cadeia curta, cadeia longa e numerosos compostos aromáticos, incluindo os hidrocarbonetos aromáticos policíclicos. (ROSENBERG, 1993).

O uso de substratos baratos ou subtilizados pode diminuir drasticamente o custo da produção de biossurfactantes. Uma variedade de subprodutos incluindo derivados de óleos vegetais, resíduos de amido, resíduos de destilaria de óleos e substâncias lácteas têm sido utilizado na produção de uma variedade de metabólitos microbianos.

A seleção do substrato depende da escolha de um resíduo com um determinado balanço de nutrientes para o crescimento do microrganismo e produção do biossurfactante. Os resíduos industriais com elevado teor de carboidratos ou lipídios são elementos necessários para serem usados como substratos para sua produção. Uma das estratégias usadas para estimular a produção de biossurfactantes é a modificação do meio nutricional. (CALVO et al., 2008).

Resíduos orgânicos e industriais têm sido apontados como possíveis substratos para a produção de biossurfactantes (MAKKAR; CAMEOTRA, 1997). Microrganismos que degradam hidrocarbonetos estão amplamente distribuídos no solo e em ambientes 
aquáticos. Populações desses microrganismos normalmente constituem menos que $1 \%$ da comunidade microbiana total, mas quando hidrocarbonetos estão presentes, essas populações aumentam até em 10\% da comunidade (ATLAS, 1995).

\subsection{1 - Glicose e sacarose}

A glicose, glucose ou dextrose, é o carboidrato fundamental de carboidratos maiores como maltose e sacarose, as células a usa como fonte de energia e intermediário metabólico, sendo o carboidrato biologicamente mais importante.

A sacarose é um glicídio formado por uma molécula de glicose e uma de frutose, é o açúcar comercial comum e está amplamente distribuído entre as plantas superiores, encontra-se na cana de açúcar de 15 a $20 \%$ e na beterraba de 14 a $18 \%$. Sacarose e glicose são substratos utilizados como padrão para a produção de biossurfactantes. Dados da literatura relatam alta produtividade quando na presença de glicose e sacarose no meio de cultura. Batista e colaboradores (2006) isolaram e caracterizaram bactérias produtoras de surfactantes/bioemulssificantes, coletadas de ambientes marinhos e terrestres contaminados com óleos residuais ou seus subprodutos, estas amostras foram avaliadas quanto à fonte de carbono (glicose, frutose, sacarose e querosene), sendo a glicose a fonte que se apresentou mais eficiente na produção de biossurfactante.

\subsection{2 - Óleos}

A produção mundial de óleos e gorduras é de cerca de 2,5 milhões de toneladas por ano, dos quais $75 \%$ são derivados de plantas. A maioria é utilizada na indústria alimentar para fabricar diversos produtos, ou diretamente em saladas. Em conseqüência, grandes quantidades de resíduos são geradas pelas indústrias de óleo e gorduras: óleos residuais, sebo, óleos marinhos, óleos provenientes de fritura. Sabe-se que a eliminação destes resíduos é um problema cada vez mais grave e, portanto novas alternativas para o uso e descarte devem ser estudadas (HABA et al., 2000).

Óleos utilizados para fritura, devido a sua composição, têm um grande potencial como fonte de carbono para o crescimento e transformação microbiana. Durante o aquecimento do óleo no processo de fritura uma série complexa de reações produz numerosos compostos de degradação. Em alguns países existem normas estabelecidas para 
o descarte destes óleos, mas no Brasil não existem leis e regulamentações que estabeleçam limites para determinar alterações desses óleos (FIRESTONE et al., 1991). Sendo assim, e dada à inexistência de uma regulamentação prévia, aliada à desinformação por parte das indústrias e dos estabelecimentos comerciais, é de suma importância dispor de métodos práticos que permitam a utilização desses resíduos poluentes a fim de promover descontaminação ou evitar contaminação ambiental.

Em um trabalho realizado por Haba e colaboradores (2000) verificou-se a produção de biossurfactante por Pseudomonas aeruginosa 47T2 NCIB 40044 (National Center for Biotechnology Information) utilizando como fonte de carbono óleos residuais de fritura (óleo de oliva e óleo de girassol). Os resultados demonstraram que ambos os substratos induziram a produção de biossurfactantes, no entanto, óleo de girassol não foi bem sucedido quanto o substrato azeite, quer para o crescimento celular ou para a produção de bissurfactante. Outras pesquisas relacionadas com a otimização da produção de biossurfactantes a partir de substratos oleosos regionais demonstraram a produção desses compostos por espécies de Candida (MARÇAL, 1991; SARUBBO et al., 1999).

Em 2004, Bednarski e colaboradores, determinaram a eficiência de produção de biossurfactantes (glicolípidios) por leveduras a partir de resíduos de refinaria de óleo.

Vega e colaboradores em 2007 verificaram a produção de biossurfactantes por Candida ingens e observaram que a composição do meio de cultivo afeta a produção de biossurfactantes e também a tensão superficial. Ainda neste ano Morita e colaboradores verificaram o potencial de conversão do glicerol em biossurfactantes por leveduras.

Barbosa e Paz (2007) utilizaram óleo de pequi para produzir biossurfactante por Chromobacterium violaceum. E Sarubbo e colaboradores também em 2007 utilizaram óleo de canola por Candida lipolytica para produção de um biossurfactante. Em ambas as pesquisas foi observada produção de biossurfactante mostrando que estes microrganismos são capazes de se desenvolverem em um meio de cultivo contendo substratos oleosos.

\subsection{3 - Vinhaça}

A vinhaça é um subproduto do processo de destilação do álcool e representa um problema ambiental importante, principalmente devido ao grande volume gerado e sua disposição no meio ambiente, uma vez que necessita uma alta demanda biológica de oxigênio (DBO) para ser biotransformada. Em média, para produzir um litro de álcool são 
produzidos 10 a 15 litros de vinhaça dependendo da qualidade da cana e do processo industrial (CORTEZ et al., 1992), o que corresponde a aproximadamente 170 bilhões de litros por ano desse resíduo no Brasil (AGRIANUAL, 2004). Considerando que cada 2 litros de vinhaça são equivalentes ao esgoto doméstico gerado por uma pessoa por dia (GONÇALVES; SILVA, 2000), a produção anual de vinhaça corresponde a uma quantidade de esgoto doméstico produzido por uma população estimada de 232 milhões de pessoas durante um ano.

Este resíduo é um liquido âmbar claro consistindo basicamente de água (93\%), sólidos orgânicos e minerais (7\%). Sua composição química é variável, dependendo, entre outros fatores, da disponibilidade de água, características da cana de açúcar e dos processos de fermentação e destilação empregados (FERRAZ et al., 1986). A vinhaça apresenta alta turbidez e pH baixo, com altos níveis de matéria orgânica (principalmente glicerol, uma fonte de carbono solúvel), potássio, cálcio e quantidades moderadas de nitrogênio e fósforo.

No Brasil é freqüente o uso da vinhaça nos campos agrícolas como um processo chamado ferti-irrigação, o qual é um substituto parcial ou total de fertilizantes minerais, principalmente potássio. A adição de vinhaça em taxas adequadas tem demonstrado aumentar o rendimento na produção da cana de açúcar, contudo, em longo prazo, a aplicação intensiva da vinhaça pode aumentar a salinidade do solo (CORAZZA, 1999), afetar a qualidade da cana e contaminar a água subterrânea (GONÇALVES; SILVA, 2000). Alguns trabalhos mostram que a vinhaça pode modificar temporariamente algumas características químicas e biológicas do solo, como pH, carbono orgânico, acidez (CAMARGO et al., 1987), a atividade microbiana e a biomassa (MINHONI; CERRI, 1987).

Tendo em vista o problema ambiental causado pela vinhaça e que a produção de etanol no Brasil está em expansão, a busca por alternativas para tratar ou reutilizar esse subproduto é de extrema importância, para a avaliação do seu potencial para produção de biossurfactantes.

\subsection{4 - Melaço}

O melaço é resultante da etapa de centrifugação ou de decantação no processo de fabricação de açúcar, tanto de cana-de-açúcar como de beterraba. Contém açúcares 
redutores e parte de sacarose não cristalizada e outros açúcares de cadeias orgânicas mais complexas de difícil degradação, tais açúcares são assimiláveis (fermentáveis). O melaço é utilizado na fermentação para produção de álcool, em especial o etanol, como matéria prima pra fabricar cachaça, rum e fermentos biológicos. Portanto é uma alternativa interessante para a produção de biossurfactantes, devido ao seu baixo custo comparado com outras fontes de açúcar, e ao fato de que apresenta muitos outros compostos ricos em carbono, além da sacarose. Compostos minerais, compostos orgânicos e vitaminas que são valiosos para o processo de fermentação (MAKKAR; CAMEOTRA, 1997; PATEL; DESAI; 1997).

Patel e Desai (1997) usaram melaço como fonte de carbono e nitrogênio para produzir um biossurfactante raminolipídico por Pseudomonas aeruginosa GS3, e obtiveram uma ótima produção desta molécula.

Bacillus subtilis MTCC (Microbial Type Culture Collection) 2423 e Bacillus subtilis MTCC 1427 foram cultivados utilizando melaço (2\% de açúcares totais) como fonte de carbono. Como resultado da acumulação de biossurfactante, a tensão superficial do meio foi reduzida. Além disso, a recuperação de um solo contaminado com óleo foi de 34\% para MTCC 1427 e 38,46\% para MTCC 2423, indicando o potencial de utilização desses biossurfactantes na recuperação de solos contaminados (MAKKAR; CAMEOTRA, 1997).

Em 2006, Rodrigues e colaboradores, avaliaram o potencial de uso de um meio fermentável alternativo para a produção de biossurfactantes por Lactococcus lactis 53 e Streptococcus thermophilus. Os resultados obtidos demonstraram que um meio complementado com soro de queijo e melaço pode ser usado como uma alternativa barata e econômica para produção de biossurfactantes por bactérias probióticas. Em 2008, Joshi e colaboradores também comprovaram o potencial do melaço como substrato para produção de tenso-ativos naturais por bactérias do gênero Bacillus.

Nitschke e Pastore (2004), selecionaram microrganismos para a produção destes biopolímeros utilizando resíduos agroindustriais, dentre eles o melaço. O melaço tem sido utilizado também, além de produção de biossurfactante, como a principal matéria prima para a produção de pululana (LAZARIDOU et al., 2002), e goma xantana (KALOGIANNIS et al., 2003). 


\section{OBJETIVOS}

Objetivos gerais

- Produzir biossurfactante com a bactéria Bacillus pumilus utilizando glicose, sacarose, vinhaça, melaço e óleo residual de fritura como substratos;

- Analisar o potencial de aplicação do biossurfactante produzido na biorremediação de amostras de solo e água contaminados com óleo.

\section{Objetivos específicos}

- Avaliar a influência dos substratos na produção de biossurfactante e no crescimento da bactéria;

- Determinar os parâmetros de produção de biossurfactante;

- Selecionar a melhor condição de cultivo para a produção de biossurfactante;

- Aplicar o biossurfactante produzido em amostras de solo e água contaminados com óleo residual de fritura;

- Avaliar o potencial de aplicação do biossurfactante nessas amostras. 


\section{MATERIAL E MÉTODOS}

\subsection{MICRORGANISMO}

Para a realização do trabalho foi utilizado a bactéria Bacillus pumilus da Coleção de Cultura Tropical (CCT) 2487, obtida da Fundação Tropical de Pesquisa e Tecnologia “André Tosello"- Campinas, SP.

\subsection{MEIOS DE CULTURA}

\subsubsection{Meio de manutenção do microrganismo}

O meio de manutenção da bactéria Bacillus pumilus foi ágar nutriente previamente autoclavado a $121^{\circ} \mathrm{C}$ por 15 minutos cuja fórmula é: extrato de carne $3,0 \mathrm{~g} / \mathrm{L}$, peptona de carne $5,0 \mathrm{~g} / \mathrm{L}$ e ágar $15 \mathrm{~g} / \mathrm{L}$. Os tubos foram mantidos sob refrigeração a $4{ }^{\circ} \mathrm{C}$.

\subsubsection{Meio mínimo ou basal}

O meio empregado para a fermentação foi o meio mínimo ou basal proposto por Bicca e colaboradores (1999). Este consta de: $\mathrm{NaNO}_{3} 7,0 \mathrm{~g} / \mathrm{L} ; \mathrm{K}_{2} \mathrm{HPO}_{4} 1,0 \mathrm{~g} / \mathrm{L} ; \mathrm{KH}_{2} \mathrm{PO}_{4}$ $0,50 \mathrm{~g} / \mathrm{L} ; \mathrm{KCl} 0,10 \mathrm{~g} / \mathrm{L} ; \mathrm{MgSO}_{4} .7 \mathrm{H}_{2} \mathrm{O} 0,50 \mathrm{~g} / \mathrm{L} ; \mathrm{CaCl}_{2} 0,01 \mathrm{~g} / \mathrm{L} ; \mathrm{FeSO}_{4} .7 \mathrm{H}_{2} \mathrm{O} 0,01 \mathrm{~g} / \mathrm{L}$; extrato de levedura $0,10 \mathrm{~g} / \mathrm{L}$; óleo diesel $1 \%(\mathrm{v} / \mathrm{v})$. O pH foi ajustado a 7,0 e o meio foi esterilizado à $121^{\circ} \mathrm{C}$ por 15 minutos.

\subsubsection{Meio de produção}

Para a produção do biossurfactante, foram utilizados frascos de Erlenmeyer de 250 $\mathrm{mL}$ contendo $5 \mathrm{~mL}$ do substrato a ser testado (previamente esterilizado): glicose, sacarose, melaço, vinhaça e óleo residual de fritura em concentrações de 1 a $5 \%$ acrescido de $45 \mathrm{~mL}$ do meio mínimo (item 4.2.2). As concentrações das fontes não convencionais foram ajustadas utilizando um refratômetro para leitura da concentração de sólidos solúveis. Todos os ensaios foram realizados em triplicata. 


\subsection{PRODUÇÃO DE BIOSSURFACTANTE}

A produção de biossurfactante foi realizada em duas etapas:

\subsubsection{Pré - fermentação}

A bactéria Bacillus pumilus foi inoculada por estrias em esgotamento em tubos inclinados de ágar nutriente (previamente esterilizados) e incubada por 24 horas a $30{ }^{\circ} \mathrm{C}$ em estufa bacteriológica (Marconi, modelo MA 032). Posteriormente, foi realizada uma suspensão bacteriana de cada tubo utilizando o meio de produção previamente estéril. A seguir, esta suspensão foi transferida para frascos de Erlenmeyer de $250 \mathrm{~mL}$ totalizando 50 $\mathrm{mL}$. Estes foram incubados a $30{ }^{\circ} \mathrm{C}$ em agitador orbital rotatório (Marconi, modelo MA 830) por 24 horas a de $200 \mathrm{rpm}$.

\subsubsection{Fermentação}

Para a produção do biossurfactante nas diferentes concentrações do substrato foi realizada uma padronização da quantidade de inóculo a partir da massa celular seca. Em uma cubeta de espectrofotômetro (Bel photonics, modelo SP 1105), foram colocados $3 \mathrm{~mL}$ do meio mínimo e adicionado um volume do pré-fermentado (item 4.3.1) até atingir um valor de densidade ótica de 0,5 no comprimento de onda de $620 \mathrm{~nm}$. Por meio de uma regra de três foi calculado o volume necessário do pré-fermentado a ser adicionado em cada frasco de Erlenmeyer contendo $50 \mathrm{~mL}$ do meio de produção. Foi realizada a contagem de células viáveis em placas de petri contento ágar nutriente o que representou $3,9 \times 10^{9} \mathrm{UFC} \cdot \mathrm{mL}^{-1}$.

Os frascos foram incubados a $30{ }^{\circ} \mathrm{C}$ e submetidos a agitação de $200 \mathrm{rpm}$ em agitador orbital rotatório (Marconi, modelo MA 830) (Figura 5). A produção de biossurfactante foi avaliada nos intervalos de fermentação de 24, 48, 72 e 96 horas. 


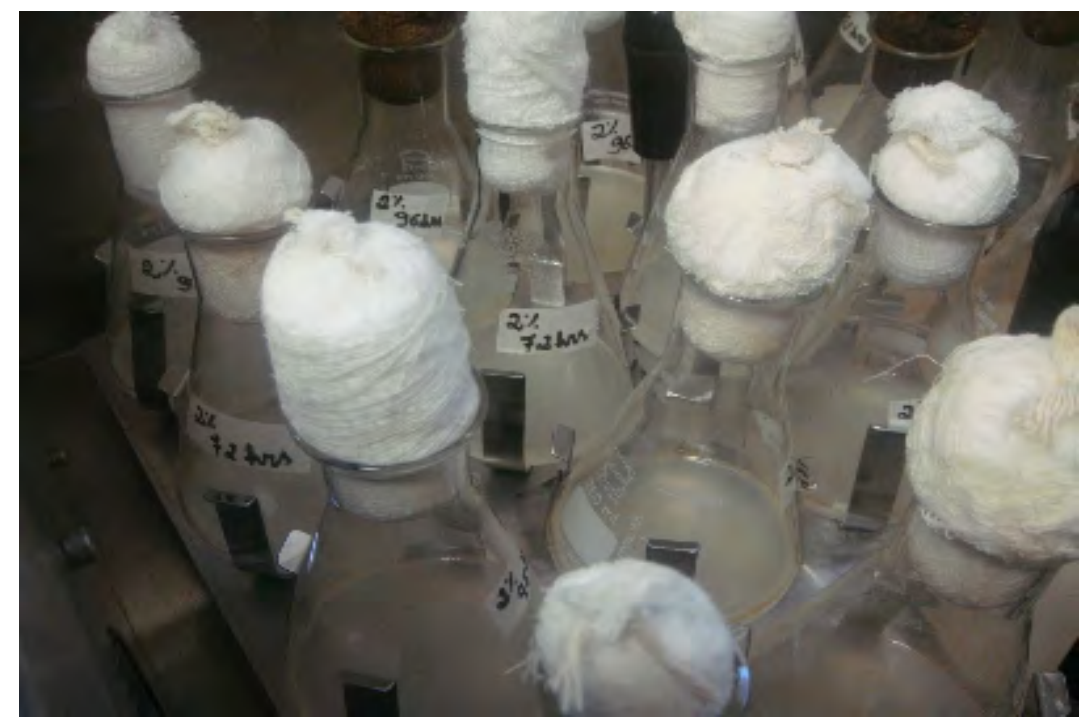

Figura 5. Frascos de Erlenmeyer incubados sob agitação de $200 \mathrm{rpm}$ a $30{ }^{\circ} \mathrm{C}$ durante 24 , 48, 72 e 96 horas em meio de produção contendo a bactéria Bacillus pumilus.

\subsubsection{Determinação do $\mathrm{pH}$}

Foi verificado o pH após cada período de fermentação sendo determinado diretamente no caldo fermentado por potenciometria, utilizando pH-metro (Marconi, modelo DM20), devidamente calibrado.

\subsection{MÉTODOS ANALÍTICOS}

\subsubsection{Determinação da presença de biossurfactante}

Após cada tempo de fermentação (24, 48, 72 e 96 horas) os caldos fermentados foram centrifugados (centrífuga - Jouan, modelo GR 2022) a $7077 \mathrm{~g}$ por 15 minutos a $4{ }^{\circ} \mathrm{C}$ para separação de células do sobrenadante (Figura 6). A determinação da presença de biossurfactante foi realizada pelas seguintes análises no sobrenadante: tensão superficial, índice de emulsificação, concentração micelar crítica (CMC). 


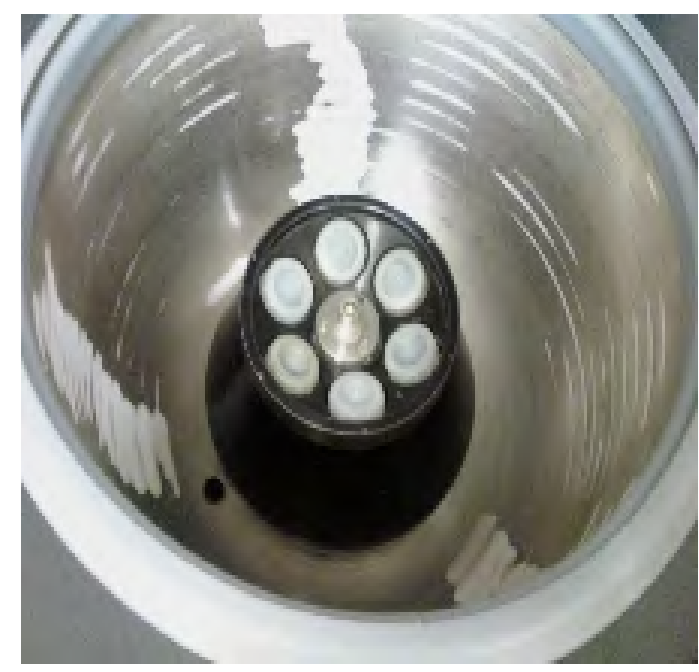

(a)

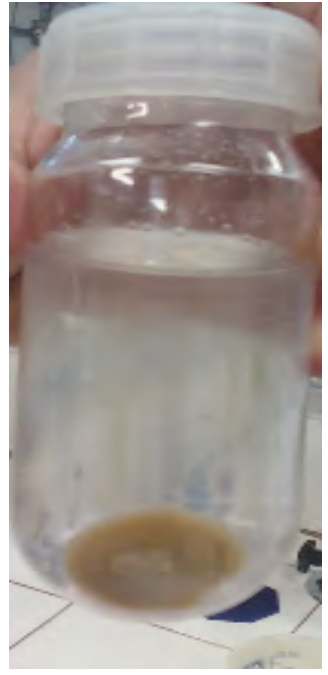

(b)

Figura 6. (a) Foto da centrífuga com tubos contendo $50 \mathrm{~mL}$ do caldo de fermentação; (b) foto da separação da célula do sobrenadante.

\subsubsection{Determinação da tensão superficial}

A determinação da tensão superficial foi realizada medindo-se diretamente um volume de $10 \mathrm{~mL}$ do caldo de fermentação livre de células em um tensiômetro de Leconde Du Nouy, na temperatura de $25^{\circ} \mathrm{C}$.

\subsection{3 Índice de emulsificação}

O índice de emulsificação foi determinado por meio da adição de $2 \mathrm{~mL}$ de tolueno em tubos de ensaio $100 \times 15 \mathrm{~mm}$ com $3,5 \mathrm{~mL}$ do caldo de cultivo livre de células obtido após a centrifugação. Os tubos foram submetidos a agitação por meio de vortex durante 2 minutos. Em seguida foi realizada a leitura nos tempos de 10 minutos $\left(\mathrm{t}_{0}\right), 24,48,72$ e 96 horas $\left(t_{1}, t_{2}, t_{3}\right.$ e $\left.t_{4}\right)$. O índice de emulsificação foi calculado segundo Iqbal e colaboradores (1995):

$\mathrm{IE}=($ altura da camada de emulsão $(\mathrm{mm}) /$ altura total da coluna $(\mathrm{mm})) \times 100$. 


\subsubsection{Determinação da atividade emulsificante}

A atividade de emulsificação foi determinada pela mistura de $2 \mathrm{~mL}$ de tolueno com 3,5 mL do caldo de cultivo livre de células, submetidos a agitação máxima em agitador de tubos por 2 minutos. Posteriormente, foi realizada a leitura em espectrofotômetro (Bel photonics, modelo SP 1105), no comprimento de onda de $620 \mathrm{~nm}$, (o branco consistiu da substituição do caldo fermentado por água).

A atividade emulsificante é dada pela fórmula:

$\mathrm{AE}=($ absorbância da amostra - absorbância do branco $)$ x diluição

\subsubsection{Determinação da concentração micelar crítica (CMC)}

Foram realizadas diluições do caldo de fermentação livre de células em água destilada até alcançar a concentração micelar crítica (CMC), na qual o biossurfactante começa a se agregar e não é mais observada a redução significativa da tensão superficial.

A determinação da $\mathrm{CMC}$ está representada por um gráfico da tensão superficial versus concentração do biossurfactante no ponto de inflexão da curva.

\subsubsection{Atividade antimicrobiana do biossurfactante}

A atividade antimicrobiana foi avaliada usando o método de disco difusão de acordo com o manual do NCCLS (National Committee for Clinical Laboratory Standards). Bactérias e leveduras crescidas por 24 horas a $30{ }^{\circ} \mathrm{C}$ em caldo nutriente e caldo sabouraud, respectivamente, foram diluídas em salina $0,85 \%$ para ajustar a turbidez de acordo com a escala de McFarland 0,5 (resultando numa suspensão de $1,5 \times 10^{8}$ UFC.mL $^{-1}$ para bactérias e 1,5 x $10^{6}$ UFC. $\mathrm{mL}^{-1}$ para leveduras). Em seguida com um swab de algodão estéril a suspensão foi plaqueada em placas de Petri de ágar nutriente e meio PDA (potato dextrose ágar).

Discos estéreis contendo 100, 50 e $25 \mu \mathrm{g}$ de biossurfactante foram colocados em cada placa e após 24 horas foi mensurado o halo de inibição. Os ensaios foram realizados em triplicata. Foram usadas como padrão os antibióticos anfotericina B e fluconazol, e as séries da Difco para bactérias Gram positivas e Gram negativas. 
Foi analisada a atividade antimicrobiana frente às bactérias: Bacillus subtilis, Bacillus cereus, Staphylococcus aureus, Bacillus thuringiensis, Salmonella enteritidis, Zymomonas mobilis, Azotobacter vinelandi, Escherichia coli; e contra as leveduras: Rhodotorula rubra, Candida tropicalis, Sporobolomyces roseus.

\subsubsection{Separação do biossurfactante}

O sobrenadante livre de células foi colocado em frascos previamente pesados, o biossurfactante foi separado por precipitação com etanol absoluto $(1: 3 \mathrm{v} / \mathrm{v})$ e em seguida mantido em repouso por um dia em uma temperatura de $4{ }^{\circ} \mathrm{C}$. Após esse procedimento foi seco em estufa a $45^{\circ} \mathrm{C}$ até peso constante. $\mathrm{O}$ biossurfactante obtido foi expresso em $\mathrm{g} / \mathrm{L}$.

\subsubsection{Construção da curva de calibração para determinação da massa celular seca}

Um volume de $50 \mathrm{~mL}$ obtido após o processo de pré-fermentação foi centrifugado a $7077 \mathrm{~g} \mathrm{a} 4{ }^{\circ} \mathrm{C}$ durante 15 minutos e o sobrenadante foi descartado. Em seguida as células foram lavadas com a mesma quantidade de água destilada $(50 \mathrm{~mL})$ e novamente foi realizado a centrifugação nas mesmas condições. O sobrenadante foi descartado novamente e a massa celular úmida foi suspensa em $50 \mathrm{~mL}$ de água destilada e em seguida foram realizadas diferentes diluições, para medição da densidade ótica destas em espectrofotômetro (Bel photonics, modelo SP 1105) no comprimento de onda de $620 \mathrm{~nm}$.

Volumes de $10 \mathrm{~mL}$ de cada diluição foram adicionados em cadinhos de porcelana, previamente secos em mufla a $550{ }^{\circ} \mathrm{C}$, por 2 horas e pesados em balança analítica, e em seguida, foram colocados para secagem em estufa a $55^{\circ} \mathrm{C}$ até peso constante.

A massa celular seca foi determinada por meio da subtração do peso dos cadinhos com células e do peso destes limpos e secos, dividido pelo volume adicionado (10 mL). A massa celular seca foi expressa em g/L. Construiu-se uma curva de calibração (Figura 7) relacionando a absorbância com a massa celular em g/L. 


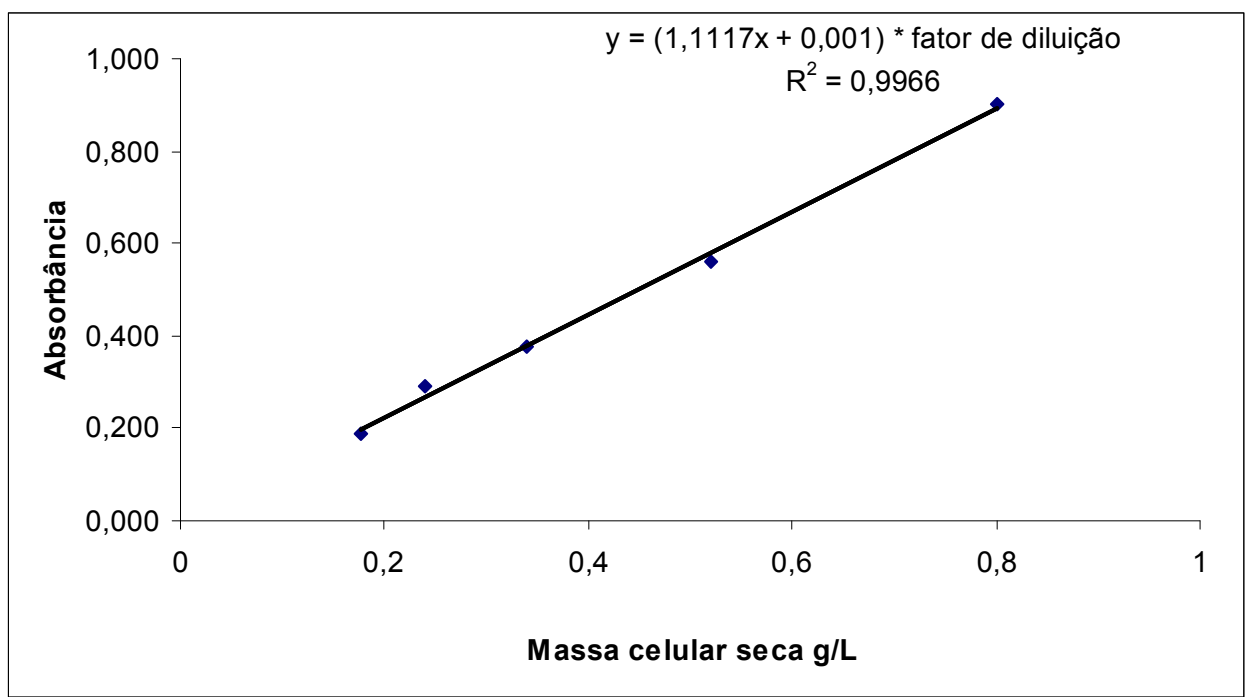

Figura 7. Curva de calibração para determinação da biomassa.

\subsubsection{Determinação do crescimento microbiano}

As células separadas no processo de centrifugação após cada período de fermentação foram suspensas em $50 \mathrm{~mL}$ de água destilada e o crescimento microbiano foi determinado pela leitura em espectrofotômetro a $620 \mathrm{~nm}$ (Bel photonics, modelo SP 1105). Os valores da absorbância foram correlacionados com a biomassa celular por meio da curva de calibração da absorbância versus massa celular (4.4.8). Todas as análises foram realizadas em triplicata.

\subsubsection{Potencial para biorremediação}

A capacidade de remoção do óleo de fritura de solos contaminados foi determinada saturando $60 \mathrm{~g}$ de areia com $5 \mathrm{~mL}$ de óleo. Porções de $20 \mathrm{~g}$ desta areia contaminada foram colocadas em placas de petri contendo soluções aquosas de $10 \mathrm{~mL}$ do sobrenadante contendo biossurfactante, este sobrenadante foi avaliado em diferentes diluições. Estas placas permaneceram em repouso por 24 horas e submetidas à análise macroscópica.

Porções de $20 \mathrm{~g}$ de areia contaminada com óleo foram colocadas com $10 \mathrm{~mL}$ de diferentes soluções do inóculo, incubadas a $30^{\circ} \mathrm{C}$ por 24 horas. E submetidas à análise macroscópica. 
Para a verificação de remoção do óleo da água, foram colocados em tubos de ensaio $2 \mathrm{~mL}$ com diferentes soluções do inóculo juntamente com $2 \mathrm{~mL}$ de água contaminada com o óleo de fritura e incubados a $30^{\circ} \mathrm{C}$ por 24 horas. Porções de $2 \mathrm{~mL}$ do sobrenadante em diferentes concentrações do biossurfactante foram colocadas também, em tubos de ensaio com $2 \mathrm{~mL}$ de água contaminada com óleo, agitadas em agitador de tubos em velocidade máxima por 10 min e mantidas em repouso por 24 horas para análise macroscópica em temperatura ambiente. Todas as análises foram realizadas em triplicata. 


\section{RESULTADOS E DISCUSSÃO}

\subsection{Variação do pH}

Foram realizadas fermentações em períodos de 24, 48, 72 e 96 horas para cada concentração do substrato testado (1 a $5 \%$ ) e analisada a variação do $\mathrm{pH}$ para cada fermentação.

Os resultados demonstraram que ocorreu uma variação do $\mathrm{pH}$ ao longo da fermentação em relação ao $\mathrm{pH}$ inicial de 7,0 sendo esta mudança diferente entre os substratos e entre as concentrações destes (Tabelas 2, 3, 4, 5 e 6).

$\mathrm{O}$ declínio do $\mathrm{pH}$ em algumas concentrações de substratos pode estar associado ao catabolismo dos carboidratos que resulta na produção de ácidos (FERREIRA 2007) que, por sua vez, está diretamente associada com o crescimento celular.

Foi observado para o substrato vinhaça e para algumas concentrações dos demais substratos um aumento do $\mathrm{pH}$ que pode ser explicado devido a secreção de substâncias no meio ou mesmo pela liberação de substâncias em decorrência a lise celular (Tabela 4).

Tabela 2: Variação do $\mathrm{pH}$ para as diferentes concentrações de glicose utilizada pela bactéria Bacillus pumilus durante a produção de biossurfactante nos períodos de 24, 48, 72 e 96 horas de incubação a $30^{\circ} \mathrm{C}$ e $200 \mathrm{rpm}$.

\begin{tabular}{cccccc}
\hline Tempo de fermentação & \multicolumn{5}{c}{ Variação de pH para glicose } \\
\hline & $\mathbf{1 \%}$ & $\mathbf{2 \%}$ & $\mathbf{3 \%}$ & $\mathbf{4 \%}$ & $\mathbf{5 \%}$ \\
\hline $\mathbf{2 4} \mathbf{~ h}$ & $6,33 \pm 0,03$ & $6,2 \pm 0,07$ & $6,03 \pm 0,03$ & $5,97 \pm 0,01$ & $6,01 \pm 0,05$ \\
$\mathbf{4 8} \mathbf{~ h}$ & $6,58 \pm 0,27$ & $5,99 \pm 0,03$ & $5,49 \pm 0,01$ & $5,89 \pm 0,00$ & $5,88 \pm 0,01$ \\
$\mathbf{7 2} \mathbf{~ h}$ & $7,57 \pm 0,15$ & $5,97 \pm 0,05$ & $5,96 \pm 0,02$ & $6,00 \pm 0,00$ & $5,95 \pm 0,05$ \\
$\mathbf{9 6} \mathbf{~ h}$ & $7,85 \pm 0,11$ & $5,95 \pm 0,14$ & $5,62 \pm 0,07$ & $6,04 \pm 0,00$ & $5,98 \pm 0,04$ \\
\hline
\end{tabular}

土: desvio padrão. 
Tabela 3. Variação do pH para as diferentes concentrações de sacarose utilizada pela bactéria Bacillus pumilus durante a produção de biossurfactante nos períodos de $24,48,72$ e 96 horas de incubação a $30^{\circ} \mathrm{C}$ e $200 \mathrm{rpm}$.

\begin{tabular}{rccccc}
\hline \multirow{2}{*}{$\begin{array}{c}\text { Tempo de } \\
\text { fermentação }\end{array}$} & $\mathbf{5 \%}$ & $\mathbf{2 \%}$ & $\mathbf{3 \%}$ & $\mathbf{4 \%}$ & $\mathbf{5 \%}$ \\
\cline { 2 - 6 } & $6,39 \pm 0,02$ & $6,36 \pm 0,10$ & $6,41 \pm 0,00$ & $6,35 \pm 0,00$ & $6,40 \pm 0,02$ \\
$\mathbf{2 4} \mathbf{h}$ & $6,06 \pm 0,03$ & $6,00 \pm 0,05$ & $6,08 \pm 0,03$ & $6,35 \pm 0,00$ & $6,40 \pm 0,02$ \\
$\mathbf{4 8} \mathbf{h}$ & $6,04 \pm 0,03$ & $6,11 \pm 0,04$ & $6,16 \pm 0,01$ & $6,30 \pm 0,01$ & $6,27 \pm 0,03$ \\
$\mathbf{7 2} \mathbf{h}$ & $5,94 \pm 0,07$ & $5,97 \pm 0,05$ & $6,31 \pm 0,09$ & $6,30 \pm 0,02$ & $6,27 \pm 0,02$ \\
\hline $\mathbf{9 6} \mathbf{h}$ & & & & & \\
\hline
\end{tabular}

土: desvio padrão.

Tabela 4. Variação do pH para as diferentes concentrações de vinhaça utilizada pela bactéria Bacillus pumilus durante a produção de biossurfactante nos períodos de 24, 48, 72 e 96 horas de incubação a $30^{\circ} \mathrm{C}$ e $200 \mathrm{rpm}$.

\begin{tabular}{cccccc}
\hline & \multicolumn{5}{c}{ variação de $\mathbf{p H}$ para vinhaça } \\
\cline { 2 - 6 } Tempo de fermentação & $\mathbf{1 \%}$ & $\mathbf{2 \%}$ & $\mathbf{3 \%}$ & $\mathbf{4 \%}$ & $\mathbf{5 \%}$ \\
\hline $\mathbf{2 4} \mathbf{h}$ & $8,22 \pm 0,14$ & $8,46 \pm 0,11$ & $8,24 \pm 0,03$ & $8,31 \pm 0,04$ & $8,24 \pm 0,04$ \\
$\mathbf{4 8} \mathbf{h}$ & $8,70 \pm 0,16$ & $8,86 \pm 0,04$ & $8,85 \pm 0,07$ & $8,80 \pm 0,14$ & $8,55 \pm 0,13$ \\
$\mathbf{7 2} \mathbf{h}$ & $8,57 \pm 0,28$ & $9,04 \pm 0,06$ & $8,88 \pm 0,05$ & $9,12 \pm 0,10$ & $8,87 \pm 0,06$ \\
$\mathbf{9 6} \mathbf{h}$ & $8,87 \pm 0,03$ & $9,00 \pm 0,00$ & $9,07 \pm 0,03$ & $9,26 \pm 0,05$ & $9,07 \pm 0,13$ \\
\hline
\end{tabular}

土: desvio padrão.

Tabela 5. Variação do pH para as diferentes concentrações de óleo residual de fritura utilizado pela bactéria Bacillus pumilus durante a produção de biossurfactante nos períodos de 24, 48, 72 e 96 horas de incubação a $30^{\circ} \mathrm{C}$ e $200 \mathrm{rpm}$.

\begin{tabular}{cccccc}
\hline \multirow{2}{*}{ Tempo de fermentação variação de pH para óleo } \\
\cline { 2 - 6 } & $\mathbf{1 \%}$ & $\mathbf{2 \%}$ & $\mathbf{3 \%}$ & $\mathbf{4 \%}$ & $\mathbf{5 \%}$ \\
\hline $\mathbf{2 4} \mathbf{h}$ & $7,42 \pm 0,07$ & $7,27 \pm 0,10$ & $6,93 \pm 0,02$ & $6,97 \pm 0,16$ & $7,01 \pm 0,00$ \\
$\mathbf{4 8} \mathbf{h}$ & $6,19 \pm 0,03$ & $6,50 \pm 0,07$ & $6,84 \pm 0,25$ & $7,02 \pm 0,04$ & $7,07 \pm 0,02$ \\
$\mathbf{7 2} \mathbf{h}$ & $6,65 \pm 0,13$ & $6,7 \pm 0,04$ & $6,95 \pm 0,20$ & $6,82 \pm 0,07$ & $6,97 \pm 0,07$ \\
$\mathbf{9 6} \mathbf{h}$ & $6,75 \pm 0,07$ & $6,98 \pm 0,03$ & $6,61 \pm 0,68$ & $7,04 \pm 0,07$ & $7,1 \pm 0,05$ \\
\hline
\end{tabular}

t: desvio padrão. 
Tabela 6. Variação do pH para as diferentes concentrações de melaço utilizado pela bactéria Bacillus pumilus durante a produção de biossurfactante nos períodos de 24, 48, 72 e 96 horas de incubação a $30^{\circ} \mathrm{C}$ e $200 \mathrm{rpm}$.

\begin{tabular}{cccccc}
\hline Tempo de fermentação & \multicolumn{5}{c}{ variação de pH para melaço } \\
\cline { 2 - 6 } & $\mathbf{1 \%}$ & $\mathbf{2 \%}$ & $\mathbf{3 \%}$ & $\mathbf{4 \%}$ & $\mathbf{5 \%}$ \\
\hline $\mathbf{2 4} \mathbf{h}$ & $6,07 \pm 0,01$ & $6,01 \pm 0,04$ & $5,90 \pm 0,01$ & $6,77 \pm 0,04$ & $6,72 \pm 0,04$ \\
$\mathbf{4 8} \mathbf{h}$ & $7,65 \pm 0,05$ & $7,58 \pm 0,37$ & $5,91 \pm 0,02$ & $6,62 \pm 0,05$ & $6,71 \pm 0,05$ \\
$\mathbf{7 2} \mathbf{h}$ & $8,49 \pm 0,02$ & $7,70 \pm 0,25$ & $7,50 \pm 0,13$ & $6,88 \pm 0,21$ & $7,40 \pm 0,03$ \\
$\mathbf{9 6} \mathbf{h}$ & $8,67 \pm 0,01$ & $7,72 \pm 0,10$ & $7,43 \pm 0,23$ & $6,25 \pm 0,10$ & $7,13 \pm 0,59$ \\
\hline
\end{tabular}

土: desvio padrão.

\subsection{Tensão superficial}

A determinação da tensão superficial foi realizada nos caldos fermentados após serem centrifugados para separação das células do sobrenadante. Esta medição foi utilizada como indicador qualitativo da produção de biossurfactante, quanto maior for a concentração do tenso-ativo no meio maior será a redução da tensão superficial. Os resultados obtidos de tensão superficial para os substratos glicose, sacarose, vinhaça, óleo residual de fritura e melaço estão expressos nas Figuras 8, 9, 10,11 e 12, respectivamente. De acordo com estas é possível observar que os valores da tensão superficial diferem entre os substratos, concentração e tempo de fermentação.

Utilizando glicose como fonte de carbono (Figura 8), na concentração de $5 \%$ com 24 horas de fermentação obteve-se a maior redução da tensão superficial $\left(37 \mathrm{mNm}^{-1}\right)$ para este substrato. De acordo com a literatura, os microrganismos para serem considerados bons produtores de biossurfactantes devem reduzir a tensão superficial do sobrenadante em relação com a da água abaixo de $40 \mathrm{mNm}^{-1}$ e em torno de $35 \mathrm{mNm}^{-1}$ (DESAI; BANAT, 1997; BATISTA et al., 2006). Este resultado encontrado com o substrato glicose indica que a bactéria Bacillus pumilus produz um biossurfactante com grande poder redutor da tensão superficial.

De acordo com as Figura 9, o biossurfactante produzido com o substrato sacarose apresentou uma maior redução da tensão superficial em relação aos outros substratos. $\mathrm{O}$ tenso-ativo produzido nesse meio foi capaz de reduzir a tensão superficial em $32 \mathrm{mNm}^{-1}$ na concentração de 4 em 96 horas e $5 \%$ em 72 horas de fermentação. Este resultado foi melhor que o encontrado por Ghojavand e colaboradores 2008 utilizando sacarose como 
fonte de carbono, eles obtiveram uma redução de $35 \mathrm{mNm}^{-1}$ por um biossurfactante produzido por um membro do grupo de Bacillus subtilis PTCC 1696 (Persian Type Cultura Collection). Neste trabalho o biossurfactante produzido reduziu em 43,96 \% a tensão superficial em relação à da água $\left(72,8 \mathrm{mNm}^{-1}\right)$.

Quando foi utilizada a vinhaça (Figura 10) como substrato para a produção de biossurfactante o melhor tempo de fermentação foi 24 horas em $4 \%$, a tensão superficial alcançada foi de $45 \mathrm{mNm}^{-1}$. Este resultado foi melhor que o encontrado por Bento e colaboradores (2003), onde o valor da tensão superficial do biossurfactante produzido por Bacillus pumilus, utilizando meio de cultura a base de sais e extrato de levedura como fonte de carbono, foi de $49,5 \mathrm{mNm}^{-1}$.

O melhor valor obtido utilizando óleo residual de fritura foi de $45 \mathrm{mNm}^{-1}$ encontrado na concentração de $2 \%$ em 24 horas de fermentação e $5 \%$ em 48 horas e 96 horas de fermentação. Utilizando melaço a melhor redução da tensão superficial foi nas concentrações de 4 e $5 \%$ em 48, 72 e 96 horas de fermentação no valor de $42 \mathrm{mNm}^{-1}$. Este resultado expressa uma menor redução da tensão superficial quando comparado com dados da literatura que indicam reduções da tensão superficial do meio utilizando melaço e óleo residual de fritura em até $35 \mathrm{mNm}^{-1}$ e $33,5 \mathrm{mNm}^{-1}$ respectivamente, utilizando outros microrganismos (JOSHI et al.,2008; LIMA, 2007).

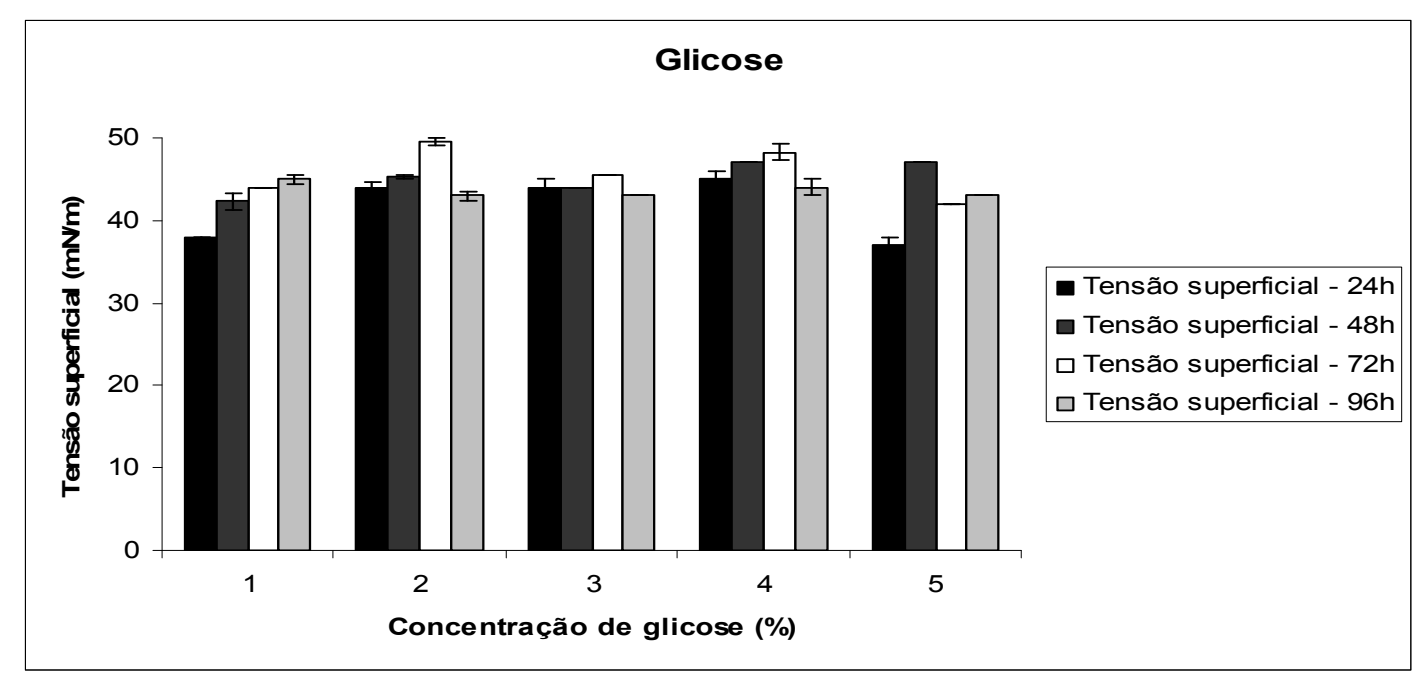

Figura 8. Determinação da tensão superficial do sobrenadante livre de células obtido em diferentes concentrações de glicose durante 24, 48, 72, 96 horas de fermentação utilizando a bactéria Bacillus pumilus incubada a $30^{\circ} \mathrm{C}$ e $200 \mathrm{rpm}$. 


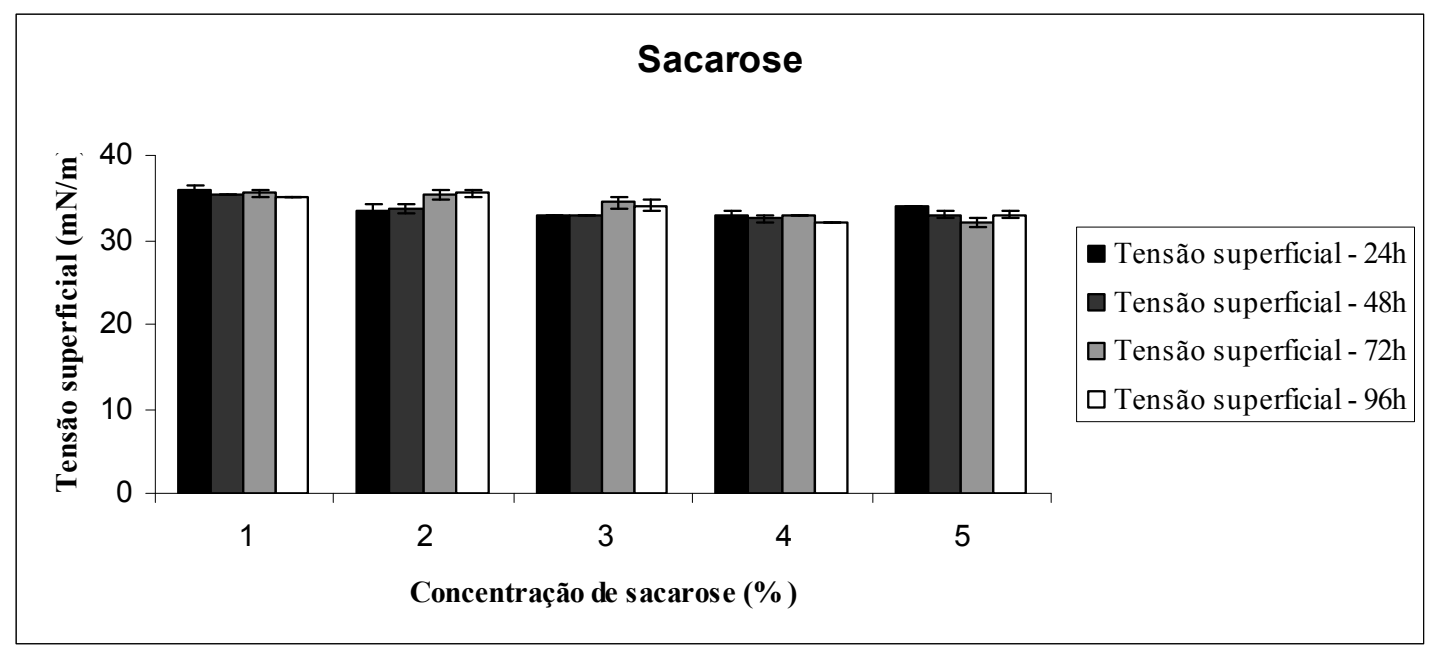

Figura 9. Determinação da tensão superficial do sobrenadante livre de células obtido em diferentes concentrações de sacarose durante 24, 48, 72, 96 horas de fermentação utilizando a bactéria Bacillus pumilus incubada a $30^{\circ} \mathrm{C}$ e $200 \mathrm{rpm}$.

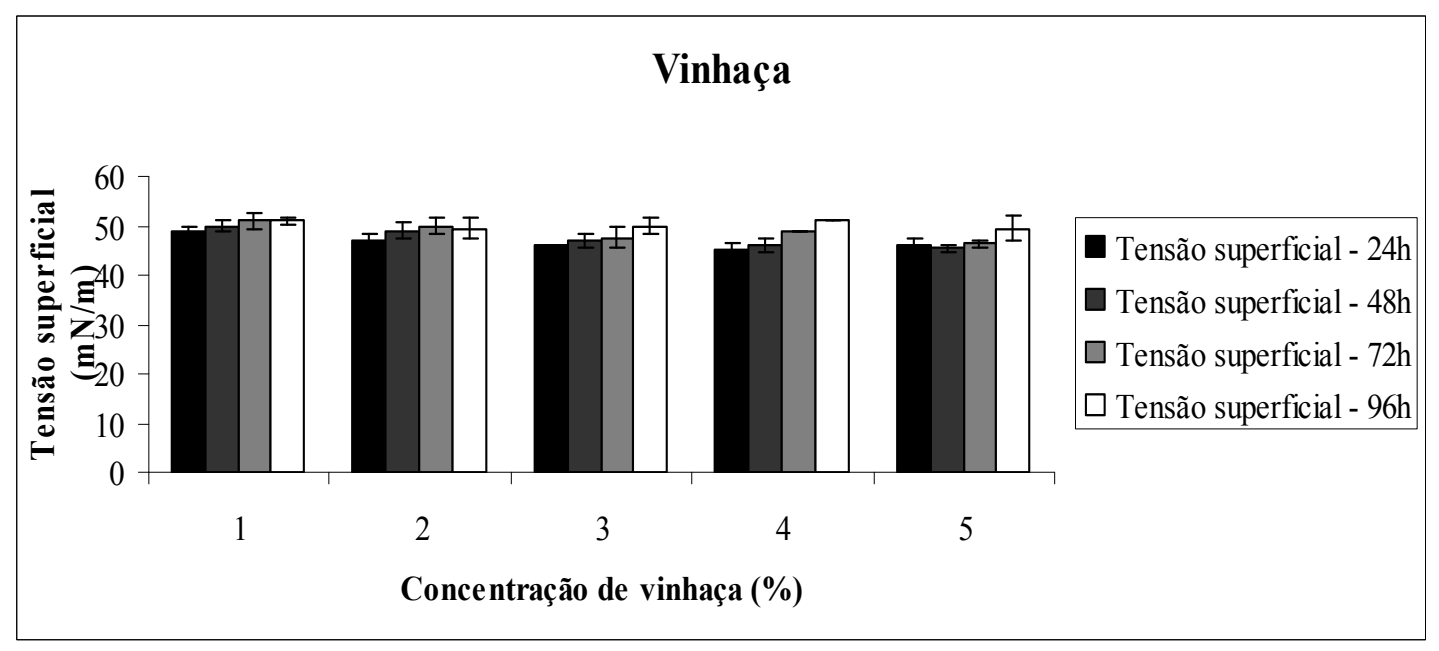

Figura 10. Determinação da tensão superficial do sobrenadante livre de células obtido em diferentes concentrações de vinhaça durante 24, 48, 72, 96 horas de fermentação utilizando a bactéria Bacillus pumilus incubada a $30^{\circ} \mathrm{C}$ e $200 \mathrm{rpm}$. 


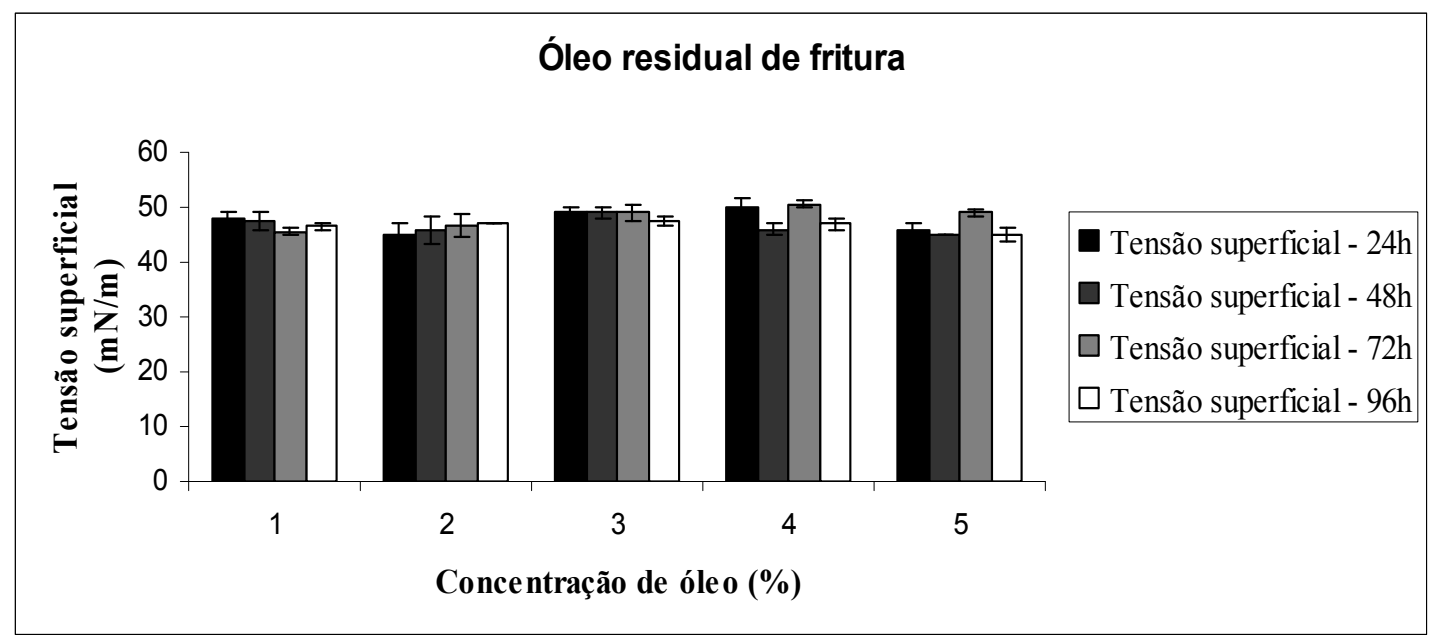

Figura 11. Determinação da tensão superficial do sobrenadante livre de células obtido em diferentes concentrações de óleo residual de fritura durante 24, 48, 72, 96 horas de fermentação utilizando a bactéria Bacillus pumilus incubada a $30{ }^{\circ} \mathrm{C}$ e 200 rpm.

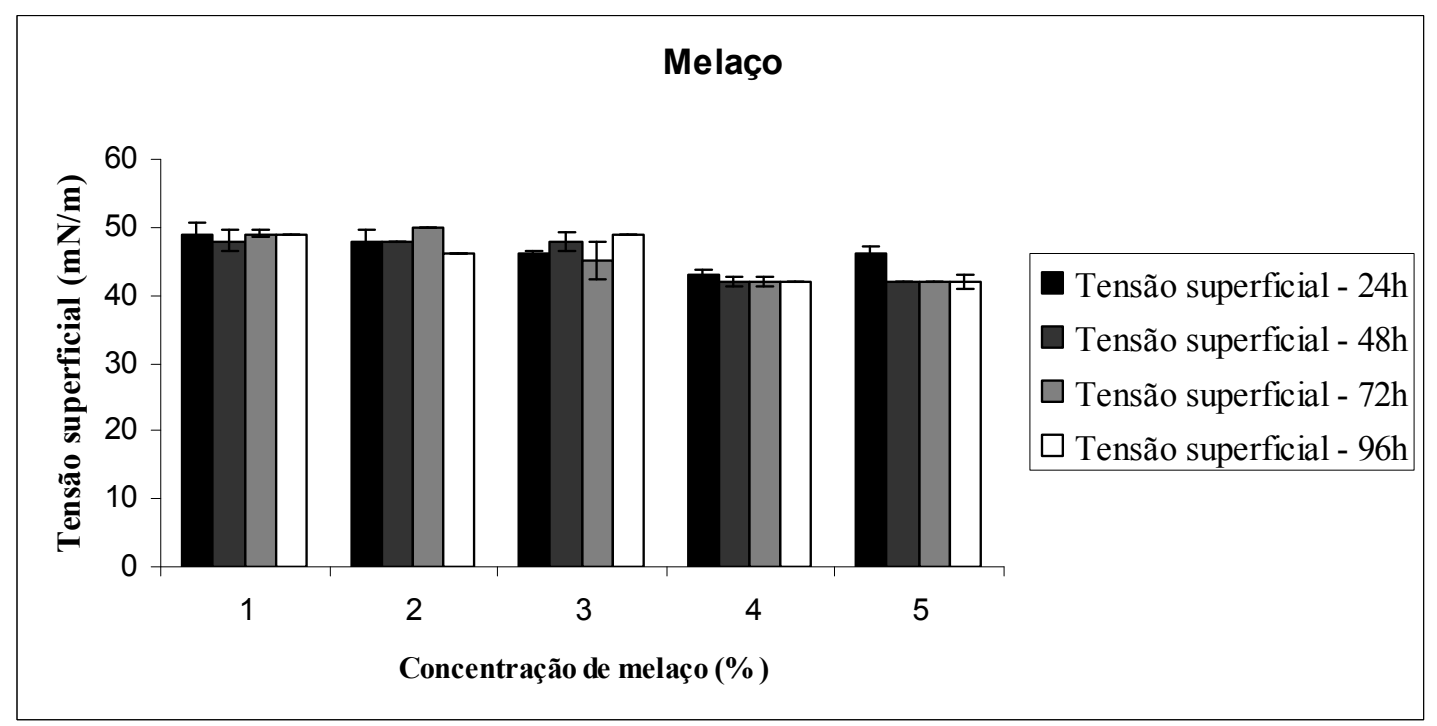

Figura 12. Determinação da tensão superficial do sobrenadante livre de células obtido em diferentes concentrações de melaço durante 24, 48, 72, 96 horas de fermentação utilizando a bactéria Bacillus pumilus incubada a $30{ }^{\circ} \mathrm{C}$ e $200 \mathrm{rpm}$. 


\section{3 Índice de emulsificação}

O índice de emulsificação é uma análise direta da presença de biossurfactante no caldo fermentado livre de células, sua presença está relacionada com altos índices de emulsificação e estabilidade do emulsificado.

O caldo fermentado livre de células foi adicionado a tolueno na proporção de 3,5: 2 $\mathrm{mL}$ e misturado em agitador de tubos por 2 minutos. Foram realizadas leituras do índice de emulsificação para o biossurfactante produzido após 10 minutos, 24, 48, 72 e 96 horas de fermentação.

O biossurfactante produzido utilizando glicose, vinhaça e óleo residual de fritura como substratos apresentou emulsificação somente no momento da mistura tolueno e o caldo fermentado, porém na primeira determinação no tempo de leitura de 10 minutos não foi observada emulsificação, portanto este biossurfactante produzido foi incapaz de formar uma emulsão estável, permanecendo inteiramente o volume de tolueno sobre o volume do caldo de fermentação, quer dizer houve separação de fases.

Este fato pode ser associado à baixa produção de biossurfactante, uma vez que existe uma relação direta entre a concentração desse produto no meio e o índice de emulsificação. Porém, na natureza a fonte de carbono pode ser limitante e influenciar no tipo de polímero produzido (CALVO et al., 2008; GEORGIOU et al., 1992). Portanto, o substrato pode ter interferido no tipo de biossurfactante produzido pela bactéria Bacillus pumilus e a atividade emulsificante deste.

A Figura 13 mostra a atividade emulsificante do biossurfactante produzido para os substratos sacarose e melaço.

Analisando somente os índices de emulsificação no tempo de 24 horas de leitura $\left(\mathrm{IE}_{24}\right)$ apresentados na Tabela 7 os maiores valores foram verificados para as concentrações de 4\% em 96 horas e $5 \%$ em 72 horas para o substrato sacarose, nestas mesmas concentrações foi encontrada a maior redução da tensão superficial.

De acordo com Sobrinho e colaboradores (2008), microrganismos que produzem tenso-ativos se dividem em duas categorias: uma que produz biossurfactante com baixo peso molecular, mas usualmente não são capazes de formar emulsões estáveis e outro grupo que produz polímeros que primariamente atuam como estabilizantes de emulsões, mas não afetam a tensão superficial. Este trabalho sugere que a bactéria Bacillus pumilus 
poderia ser incluída na primeira categoria de microrganismos porque foi capaz de reduzir a tensão superficial, mas não foi capaz de formar emulsões estáveis com tolueno (Figura 13).

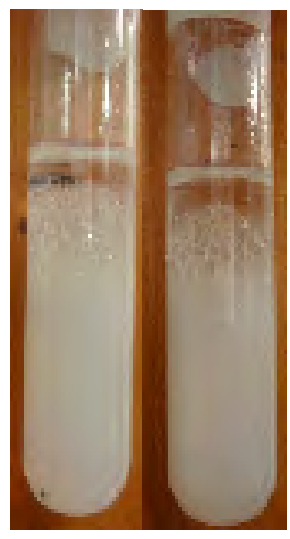

(a)

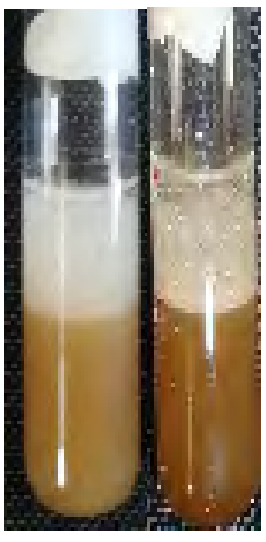

(b)

Figura 13. Emulsificação de tolueno adicionado ao caldo livre de células para a determinação do índice de emulsificação para o biossurfactante produzido com sacarose (a), e melaço (b).

A Tabela 8 mostra os resultados do índice de emulsificação utilizando melaço como substrato. $\mathrm{O} \mathrm{IE}_{24}$ foi maior na concentração de 1 e $2 \%$ em 96 horas de fermentação, diferentemente onde foi observada a maior redução da tensão superficial. De um modo geral o que se observou foi que o índice de emulsificação diminuiu com o decorrer do tempo, porém alguns índices se mantiveram de uma leitura para outra após 24 horas de repouso. 
Tabela 7. Determinação do índice de emulsificação nos caldos livres de células obtidos durante 24, 48, 72 e 96 horas de fermentação com a bactéria Bacillus pumilus incubada a $30^{\circ} \mathrm{C}$ e $200 \mathrm{rpm}$ utilizando sacarose como substrato.

\begin{tabular}{ccccccc}
\hline \multicolumn{7}{c}{ Índice de emulsificação (\%) com $\mathbf{2 4}$ horas de produção } \\
\hline \\
Concentração de sacarose (\%) & $\mathbf{t}(\mathbf{1 0} \mathbf{~} \mathbf{~ i n})$ & $\mathbf{t}(\mathbf{2 4} \mathbf{~})$ & $\mathbf{t}(\mathbf{4 8} \mathbf{~})$ & $\mathbf{T}(\mathbf{7 2} \mathbf{~ h})$ & $\mathbf{t}$ (96 $\mathbf{~})$ \\
\hline $\mathbf{1}$ & 0,00 & 0,00 & 0,00 & 0,00 & 0,00 \\
$\mathbf{2}$ & 0,00 & 0,00 & 0,00 & 0,00 & 0,00 \\
$\mathbf{3}$ & 0,00 & 0,00 & 0,00 & 0,00 & 0,00 \\
$\mathbf{4}$ & $14,13 \pm 0$ & 0,00 & 0,00 & 0,00 & 0,00 \\
$\mathbf{5}$ & $25,00 \pm 0$ & 0,00 & 0,00 & 0,00 & 0,00 \\
\hline
\end{tabular}

\begin{tabular}{cccccc}
\hline \multicolumn{7}{c}{ Índice de emulsificação (\%) com $\mathbf{4 8}$ horas de produção } \\
\hline Concentração de sacarose (\%) & $\mathbf{t}(\mathbf{1 0} \mathbf{~} \mathbf{m i n})$ & $\mathbf{t} \mathbf{( 2 4} \mathbf{~ h})$ & $\mathbf{t}(\mathbf{4 8} \mathbf{~})$ & $\mathbf{T}(\mathbf{7 2} \mathbf{~})$ & $\mathbf{t} \mathbf{( 9 6} \mathbf{~ h})$ \\
\hline $\mathbf{1}$ & $25,00 \pm 0$ & 0,00 & 0,00 & 0,00 & 0,00 \\
$\mathbf{2}$ & $26,66 \pm 1,44$ & 0,00 & 0,00 & 0,00 & 0,00 \\
$\mathbf{3}$ & $15 \pm 3,53$ & $10,00 \pm 3,53$ & 0,00 & 0,00 & 0,00 \\
$\mathbf{4}$ & $30,00 \pm 0$ & $10,83 \pm 3,81$ & $8,33 \pm 0$ & $7,5 \pm 0$ & 0,00 \\
$\mathbf{5}$ & $22,50 \pm 2,53$ & $10,95 \pm 0$ & $10,00 \pm 0$ & 0,00 & 0,00 \\
\hline
\end{tabular}

\begin{tabular}{|c|c|c|c|c|c|}
\hline \multicolumn{6}{|c|}{ Índice de emulsificação (\%) com 72 horas de produção } \\
\hline Concentração de sacarose (\%) & $\mathrm{T}(10 \mathrm{~min})$ & $t(24 \mathrm{~h})$ & $t(48 \mathrm{~h})$ & $\mathrm{t}(\mathbf{7 2} \mathrm{h})$ & $t(96 \mathrm{~h})$ \\
\hline 1 & $34,16 \pm 1,75$ & $17,50 \pm 0$ & $12,50 \pm 0$ & $12,5 \pm 0$ & $12,50 \pm 0$ \\
\hline 2 & $37,50 \pm 0$ & $12,50 \pm 0$ & $5,00 \pm 0$ & 0,00 & 0,00 \\
\hline 3 & $25,00 \pm 0$ & $12,50 \pm 0$ & $12,50 \pm 0$ & $7,50 \pm 0$ & 0,00 \\
\hline 4 & $29,16 \pm 2,81$ & $18,33 \pm 1,70$ & $15,00 \pm 2,88$ & $7,50 \pm 0$ & $2,50 \pm 0$ \\
\hline 5 & $30,00 \pm 0$ & $18,40 \pm 0$ & $10,00 \pm 0$ & $3,75 \pm 0$ & 0,00 \\
\hline
\end{tabular}

Índice de emulsificação (\%) com 96 horas de produção

\begin{tabular}{cccccc}
$\begin{array}{c}\text { Concentração de sacarose } \\
(\mathbf{\%})\end{array}$ & $\mathbf{t}(\mathbf{1 0} \mathbf{~} \mathbf{m i n})$ & $\mathbf{t}(\mathbf{2 4} \mathbf{h})$ & $\mathbf{t}(\mathbf{4 8} \mathbf{~ h})$ & $\mathbf{t}(\mathbf{7 2} \mathbf{h})$ & $\mathbf{t} \mathbf{( 9 6} \mathbf{~ h})$ \\
\hline $\mathbf{1}$ & $25,00 \pm 0$ & $25,00 \pm 0$ & $12,50 \pm 0$ & $7,50 \pm 0$ & $7,50 \pm 0$ \\
$\mathbf{2}$ & $25,00 \pm 0$ & $25,00 \pm 0$ & $20,00 \pm 0$ & $12,50 \pm 0$ & $7,50 \pm 0$ \\
$\mathbf{3}$ & $32,50 \pm 0$ & $25,50 \pm 0$ & $20,00 \pm 0$ & $12,50 \pm 0$ & $12,50 \pm 0$ \\
$\mathbf{4}$ & $33,30 \pm 1,44$ & $25,83 \pm 0$ & $23,33 \pm 0$ & $18,33 \pm 0$ & $8,75 \pm 1,76$ \\
$\mathbf{5}$ & $37,50 \pm 0$ & $25,00 \pm 1,76$ & $17,50 \pm 0$ & $10,00 \pm 1,76$ & $2,50 \pm 0$ \\
\hline
\end{tabular}

士: desvio padrão. 
Tabela 8. Determinação do índice de emulsificação nos caldos livres de células obtidos durante 24, 48, 72 e 96 horas de fermentação com a bactéria Bacillus pumilus incubada a $30^{\circ} \mathrm{C}$ e $200 \mathrm{rpm}$ utilizando melaço como substrato.

\begin{tabular}{|c|c|c|c|c|c|}
\hline \multicolumn{6}{|c|}{ Índice de emulsificação (\%) com 24 horas de produção } \\
\hline Concentração de melaço (\%) & $t(10 \mathrm{~min})$ & $t(24 \mathrm{~h})$ & $t(48 \mathrm{~h})$ & $t(72 \mathrm{~h})$ & $t(96 \mathrm{~h})$ \\
\hline 1 & $32,50 \pm 0$ & $27,50 \pm 32$ & $23,75 \pm 1,7$ & $22,50 \pm 3$ & $22,00 \pm 1,7$ \\
\hline 2 & $32,50 \pm 2$ & $25,00 \pm 0$ & $27,50 \pm 3$ & $27,50 \pm 3$ & $26,25 \pm 0$ \\
\hline 3 & $32,50 \pm 0$ & $30,00 \pm 0$ & $30,00 \pm 0$ & $27,50 \pm 3$ & $25,00 \pm 0$ \\
\hline 4 & $36,25 \pm 1,7 \quad 1$ & $11,25 \pm 1,7$ & $5,00 \pm 0$ & $2,50 \pm 0$ & $2,50 \pm 0$ \\
\hline 5 & $38,33 \pm 1,7 \quad 1$ & $11,25 \pm 1,7 \quad 2$ & $22,50 \pm 2,5 \quad 2$ & $21,25 \pm 1,7$ & $17,50 \pm 0$ \\
\hline \multicolumn{6}{|c|}{ Índice de emulsificação (\%) com 48 horas de produção } \\
\hline Concentração de melaço (\%) & $t(10 \mathrm{~min})$ & $t(24 \mathrm{~h})$ & $t(48 h)$ & $t(72 \mathrm{~h})$ & $t(96 \mathrm{~h})$ \\
\hline 1 & $25,00 \pm 0$ & $3,75 \pm 1,7$ & $2,50 \pm 0$ & 0,00 & 0,00 \\
\hline 2 & $25,00 \pm 5$ & $7,50 \pm 0$ & $5,00 \pm 0$ & $5,00 \pm 0$ & $2,50 \pm 0$ \\
\hline 3 & $37,50 \pm 0$ & $33,70 \pm 5$ & $21,20 \pm 5$ & $12,50 \pm 0$ & $12,50 \pm 0$ \\
\hline 4 & $37,50 \pm 0$ & $11,6 \pm 1,4$ & $9,16 \pm 1,4$ & $7,50 \pm 0$ & $5,00 \pm 0$ \\
\hline 5 & $35,00 \pm 3,5$ & $25 \pm 0$ & $12,00 \pm 0$ & $11,60 \pm 1,4$ & $11,00 \pm 2$ \\
\hline \multicolumn{6}{|c|}{ Índice de emulsificação (\%) com 72 horas de produção } \\
\hline Concentração de melaço (\%) & $t(10 \mathrm{~min})$ & $t(24 \mathrm{~h})$ & $t(48 h)$ & $t(72 \mathrm{~h})$ & $t(96 \mathrm{~h})$ \\
\hline 1 & $42,50 \pm 0$ & $10,00 \pm 0$ & $5,00 \pm 0$ & $2,50 \pm 0$ & $2,50 \pm 0$ \\
\hline 2 & $32,25 \pm 1,7$ & $7 \quad 27,50 \pm 3,5$ & $5 \quad 26,20 \pm 5$ & $25,00 \pm 3$ & $25,00 \pm 0$ \\
\hline 3 & $25,00 \pm 2,5$ & $5,00 \pm 0$ & $2,50 \pm 0$ & $2,50 \pm 0$ & $2,50 \pm 0$ \\
\hline 4 & $37,50 \pm 0$ & $8,75 \pm 1,7$ & $5,00 \pm 0$ & $17,50 \pm 0$ & $8,75 \pm 1,7$ \\
\hline 5 & $24,16 \pm 1,4$ & $10,00 \pm 0$ & $3,30 \pm 1,4$ & $4 \quad 2,50 \pm 0$ & $2,50 \pm 0$ \\
\hline
\end{tabular}

Índice de emulsificação (\%) com 96 horas de produção

\begin{tabular}{|c|c|c|c|c|c|}
\hline Concentração de melaço (\%) & $t(10 \mathrm{~min})$ & $t(24 \mathrm{~h})$ & $t(48 \mathrm{~h})$ & $t(72 \mathrm{~h})$ & $t(96 h)$ \\
\hline & $40,83 \pm 3$ & $33,75 \pm 1,7$ & $30,00 \pm 2$ & $29,00 \pm 1,7$ & $28,75 \pm 1,7$ \\
\hline & $40,00 \pm 0$ & $33,75 \pm 5$ & $33,00 \pm 0$ & $23,75 \pm 1,7$ & $22,5 \pm 3$ \\
\hline & $37,50 \pm 0$ & $31,20 \pm 1,7$ & $25,00 \pm 0$ & $25,00 \pm 0$ & $24,00 \pm 3$ \\
\hline & $435,83 \pm 1,4$ & $13,30 \pm 1,4$ & $11,25 \pm 1,7$ & $10,00 \pm 0$ & $7,50 \pm 0$ \\
\hline & $25,00 \pm 0$ & $10,00 \pm 3$ & $12,50 \pm 0$ & $12,50 \pm 0$ & $2,50 \pm 0$ \\
\hline
\end{tabular}

¥: desvio padrão.

\subsection{Concentração Micelar Crítica (CMC)}

A concentração micelar crítica $(\mathrm{CMC})$ foi determinada pela diluição do caldo de fermentação livre de células e foi expressa pela medição da tensão superficial em função da concentração de biossurfactante. Nas Figuras 14, 15, 16, 17 e 18 estão expressas a CMC 
do biossurfactante produzido com os substratos glicose, sacarose, vinhaça, óleo residual de fritura e melaço respectivamente.

A CMC é usada como um índice para avaliar a atividade do surfactante (FOX; BALA 2000). De acordo com Mulligan e colaboradores (2001) a eficiência do biossurfactante é medida por meio da CMC e esta varia de 0,001 a $2 \mathrm{~g} / \mathrm{L}$. Como indicado nas Figuras o biossurfactante produzido em todos os substratos apresentou uma CMC abaixo de $2 \mathrm{~g} / \mathrm{L}$, indicando ser eficiente.

Quanto mais baixo for a CMC melhor é o biossurfactante (CHRISTOFI; IVSHINA, 2002), nestes resultados obtidos o valor mais baixo $(0,2-0,3 \mathrm{~g} / \mathrm{L})$ foi encontrado quando utilizado o substrato óleo residual de fritura. Porém este biossurfactante demonstrou ser menos eficiente na capacidade emulsificante e apresentou uma baixa redução da tensão superficial quando comparado com a fermentação dos demais substratos; isto se deve a que o tipo de biossurfactante produzido é influenciado pelo substrato.

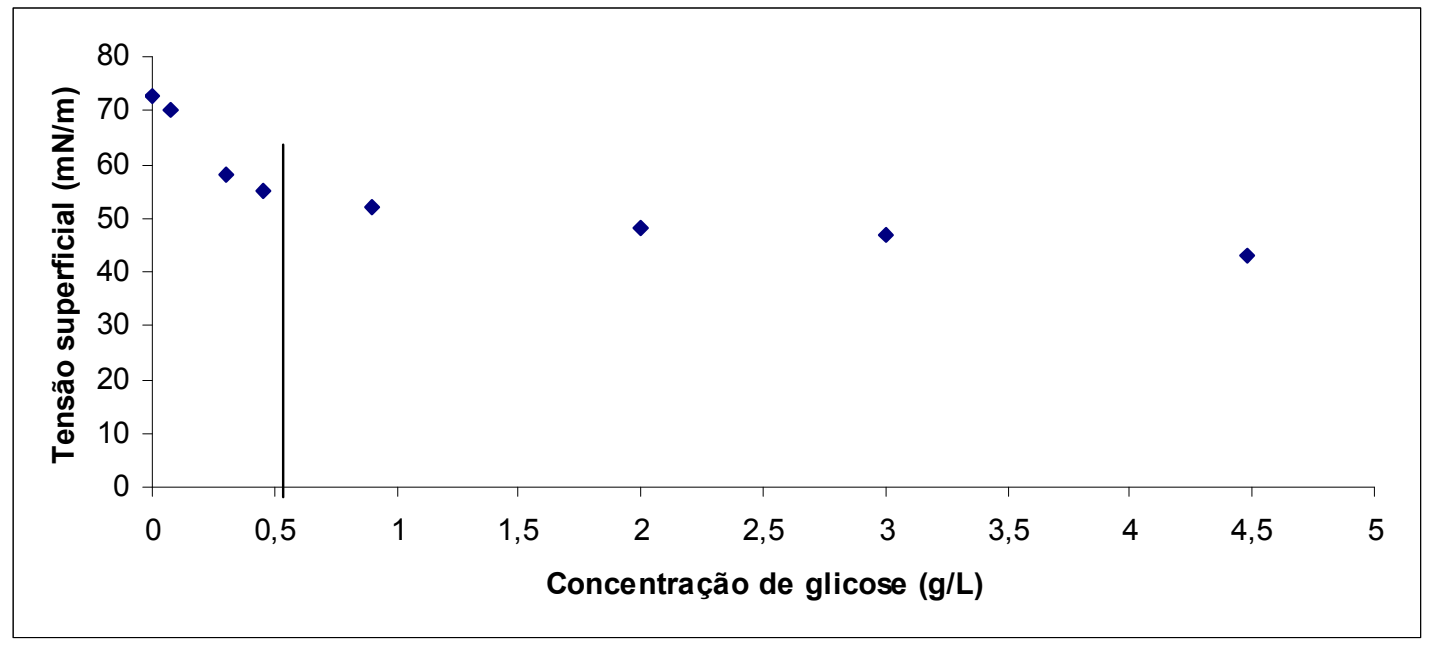

Figura 14. Determinação da concentração micelar crítica (CMC) no sobrenadante livre de células quando foi utilizada glicose como substrato pela bactéria Bacillus pumilus durante $24,48,72$ e 96 horas de fermentação incubada a $30^{\circ} \mathrm{C}$ e $200 \mathrm{rpm}$. 


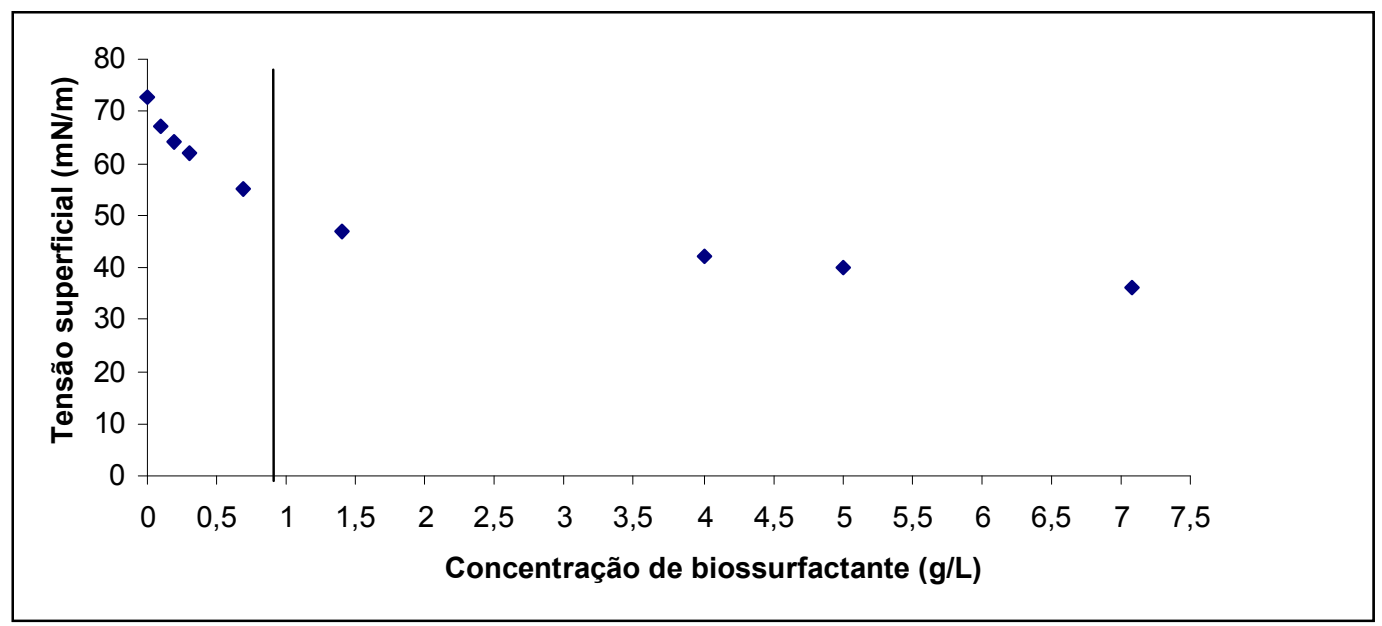

Figura 15. Determinação da concentração micelar crítica (CMC) no sobrenadante livre de células quando foi utilizada sacarose como substrato pela bactéria Bacillus pumilus durante $24,48,72$ e 96 horas de fermentação incubada a $30^{\circ} \mathrm{C}$ e 200 rpm.

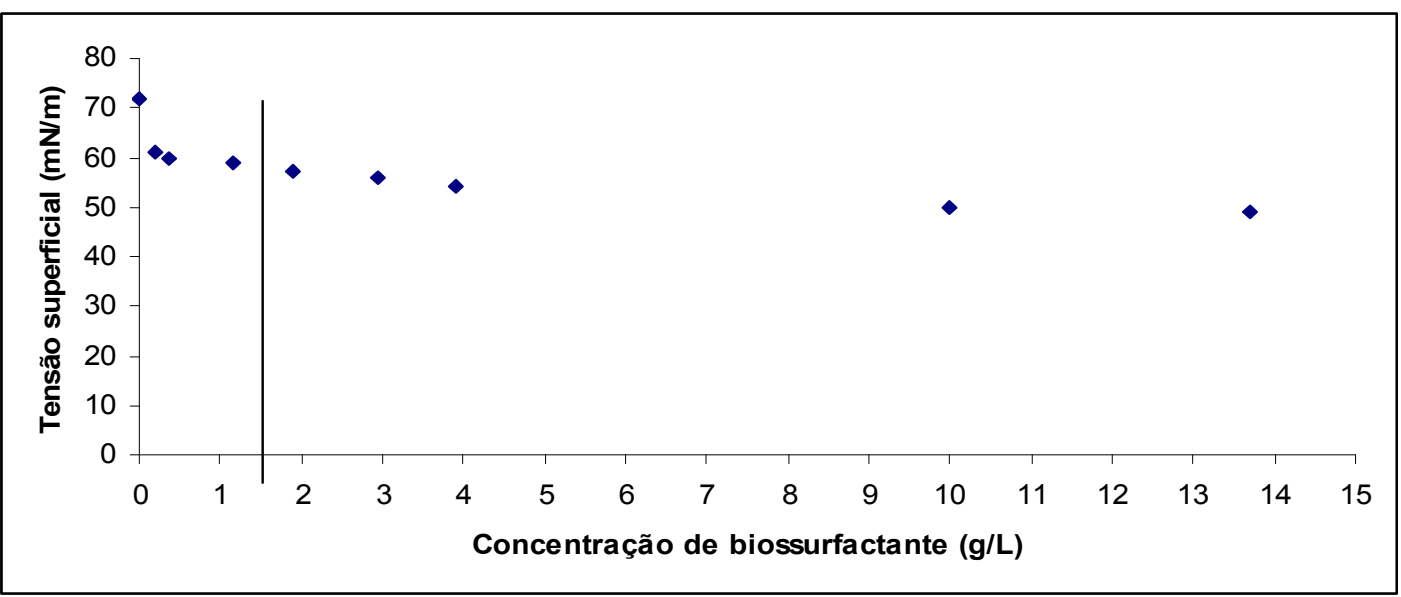

Figura 16. Determinação da concentração micelar crítica (CMC) no sobrenadante livre de células quando foi utilizada vinhaça como substrato pela bactéria Bacillus pumilus durante $24,48,72$ e 96 horas de fermentação incubada a $30^{\circ} \mathrm{C}$ e 200 rpm. 


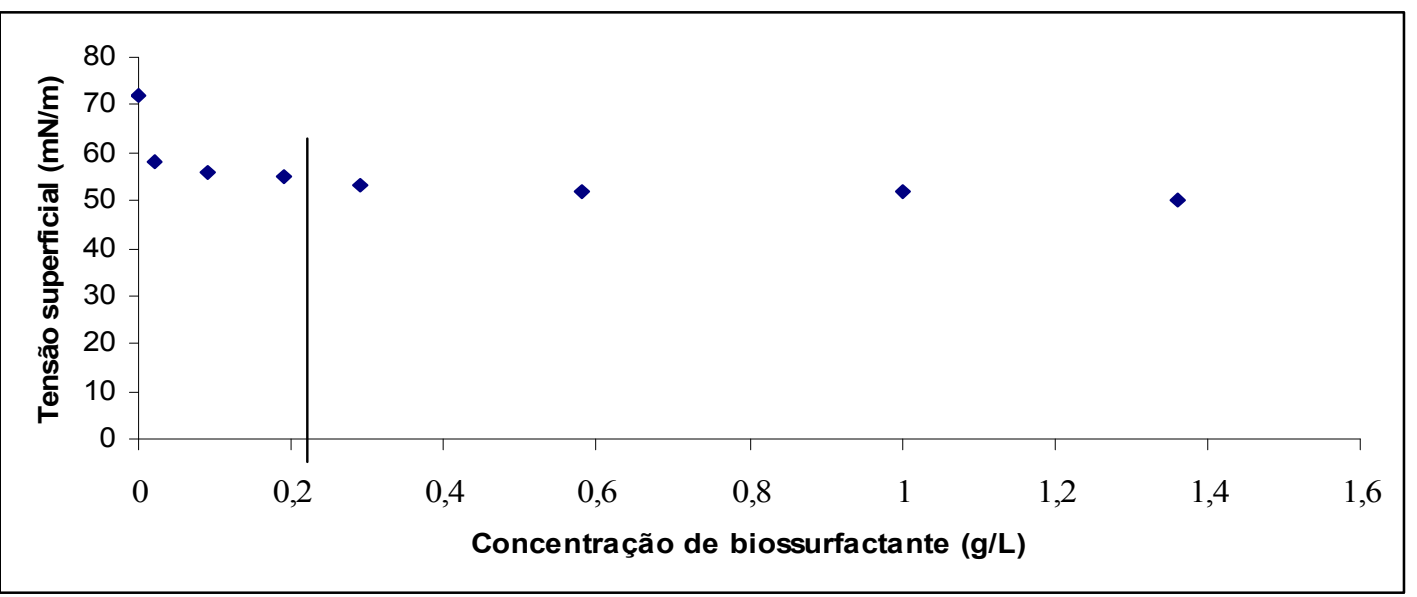

Figura 17. Determinação da concentração micelar crítica (CMC) no sobrenadante livre de células quando foi utilizado óleo residual de fritura como substrato pela bactéria Bacillus pumilus durante 24, 48, 72 e 96 horas de fermentação incubada a $30^{\circ} \mathrm{C}$ e $200 \mathrm{rpm}$.

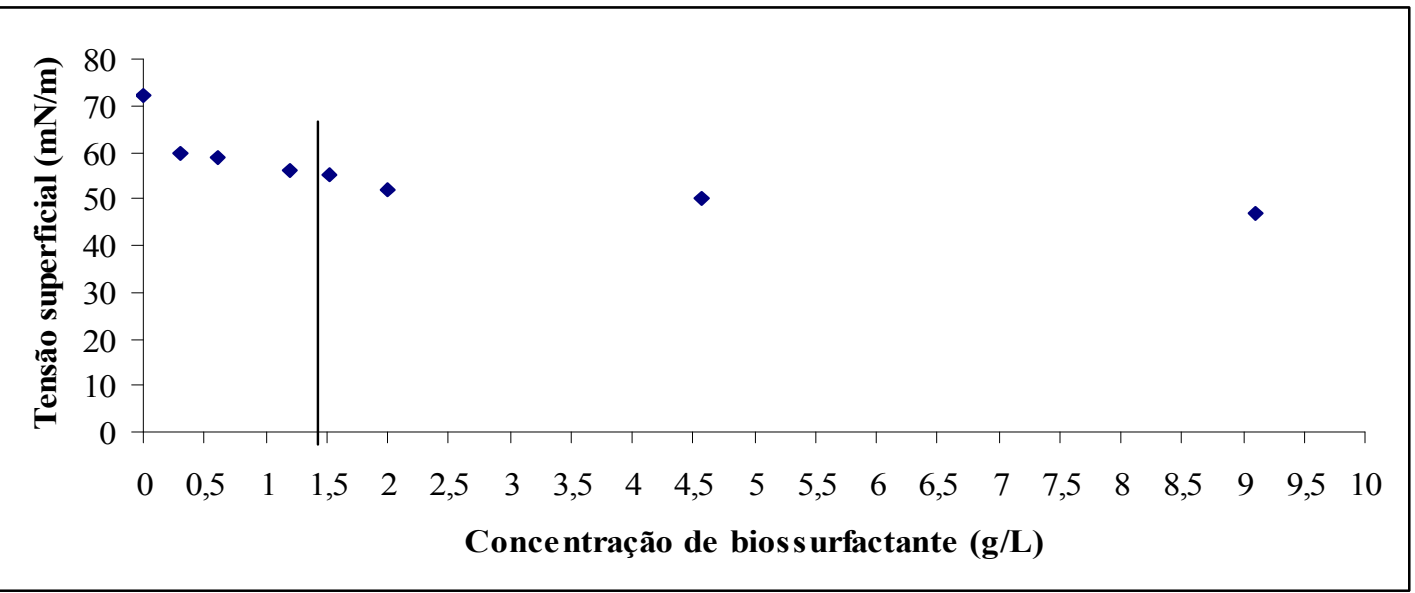

Figura 18. Determinação da concentração micelar crítica (CMC) no sobrenadante livre de células quando foi utilizado melaço como substrato pela bactéria Bacillus pumilus durante $24,48,72$ e 96 horas de fermentação incubada a $30{ }^{\circ} \mathrm{C}$ e 200 rpm.

\subsection{Separação do biossurfactante}

Um volume de $30 \mathrm{~mL}$ do sobrenadante livre de células resultante da centrifugação foi utilizado para quantificar a produção do biossurfactante em $\mathrm{g} / \mathrm{L}$, por meio da 
precipitação com etanol absoluto e secagem à estufa à vácuo até peso constante. As Figuras 19, 20, 21, 22 e 23 apresentam os resultados obtidos da produção de biossurfactante relacionando estes com os resultados da tensão superficial relatados no item 5.2.

Em um trabalho realizado por Nayak; Vijaykuma; Karegoudar (2009) verificou-se que Pseudoxanthomonas spp. foi capaz de produzir $0,15 \mathrm{~g} / \mathrm{L}$ de biossurfactante utilizando a glicose como fonte de carbono. Neste trabalho a bactéria Bacillus pumilus, produziu $17,83 \mathrm{~g} / \mathrm{L}$ e $17,67 \mathrm{~g} / \mathrm{L}$ na concentração de $5 \%$ de glicose nos tempos de 24 e 72 horas de fermentação, respectivamente (Figura 19).

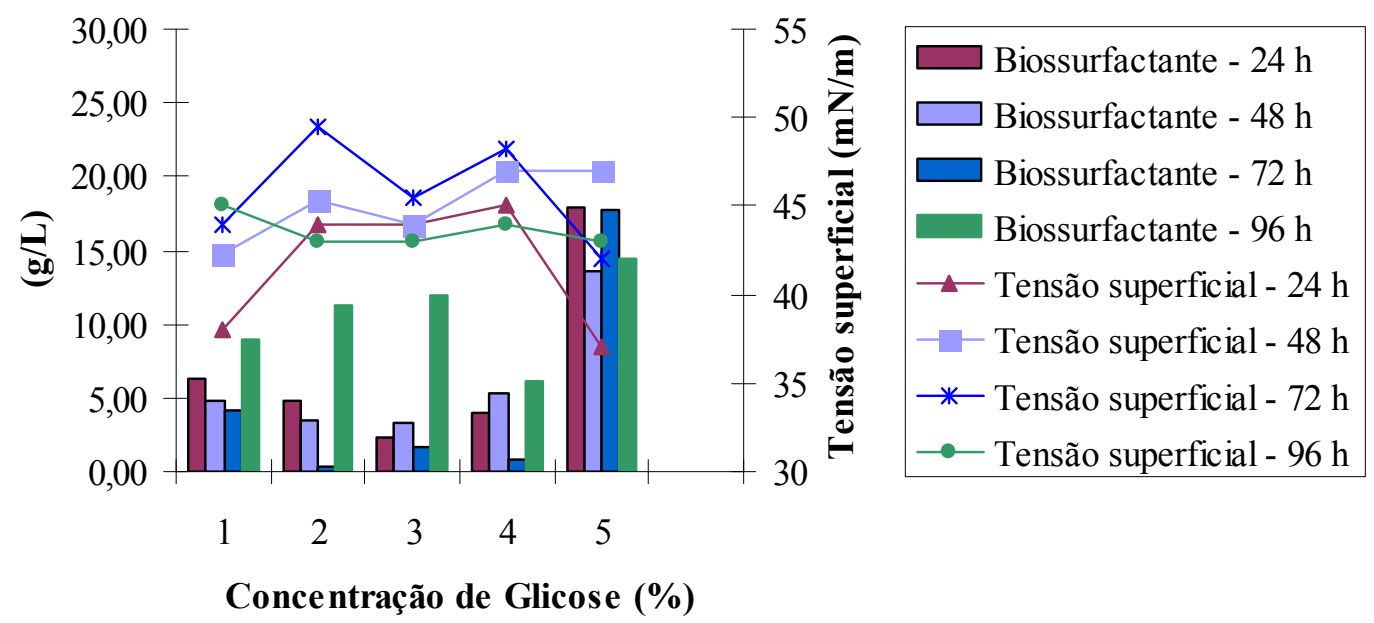

Figura 19. Relação da produção de biossurfactante $(\mathrm{g} / \mathrm{L})$ e da tensão superficial $(\mathrm{mN} / \mathrm{m})$ durante a fermentação de 24, 48, 72 e 96 horas, nas diferentes concentrações de glicose utilizadas por Bacillus pumilus incubada a $30^{\circ} \mathrm{C}$ e $200 \mathrm{rpm}$.

Para o substrato sacarose, a maior produção de biossurfactante $(26,83 \mathrm{~g} / \mathrm{L})$, ocorreu no tempo de fermentação de 96 horas na concentração de 4\% onde foi observado o menor valor de tensão superficial e o melhor índice de emulsificação. Para 2\% e 3\% de sacarose o melhor tempo de produção foi de 24 horas, esse resultado é bastante relevante uma vez que concentrações baixas de sacarose foram capazes de estimular em um curto período de tempo uma produção relativamente alta quando comparada com a maior produção encontrada (Figura 20). 


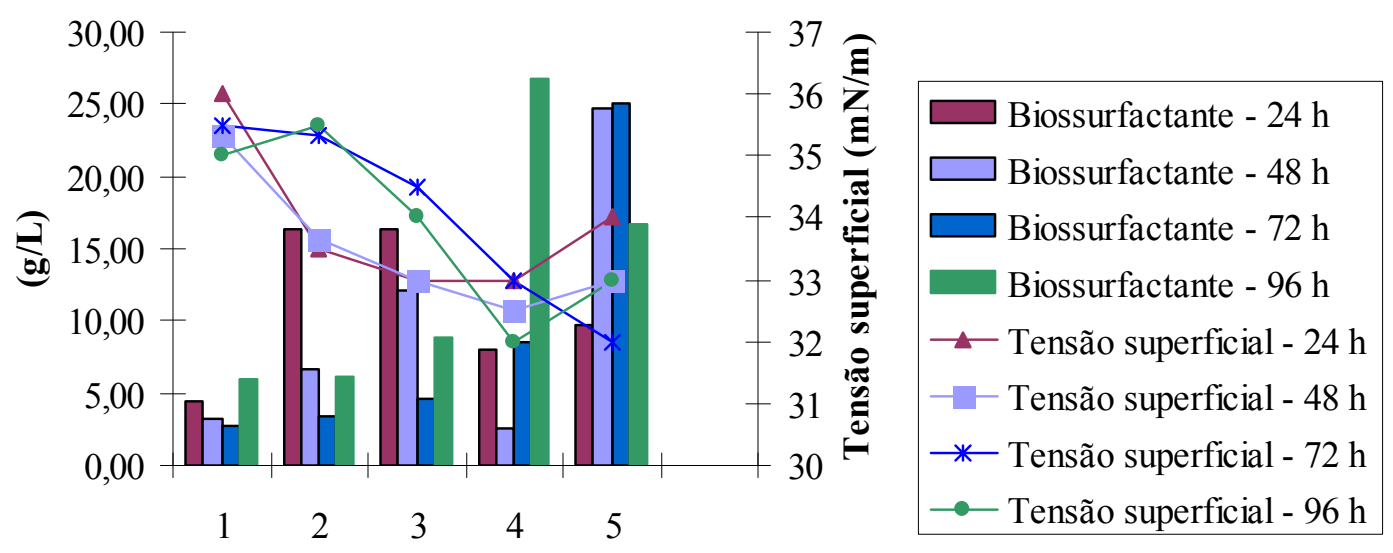

Concentração de Sacarose (\%)

Figura 20. Relação da produção de biossurfactante e da tensão superficial durante a fermentação de 24, 48, 72 e 96 horas nas diferentes concentrações de sacarose utilizadas por Bacillus pumilus incubada a $30^{\circ} \mathrm{C}$ e $200 \mathrm{rpm}$.

De acordo com a Figura 21 a maior produção de biossurfactante ocorreu utilizando o substrato vinhaça na concentração de $5 \%$ em 48 e 24 horas de fermentação, 27,7 g/L e $20,4 \mathrm{~g} / \mathrm{L}$, respectivamente.

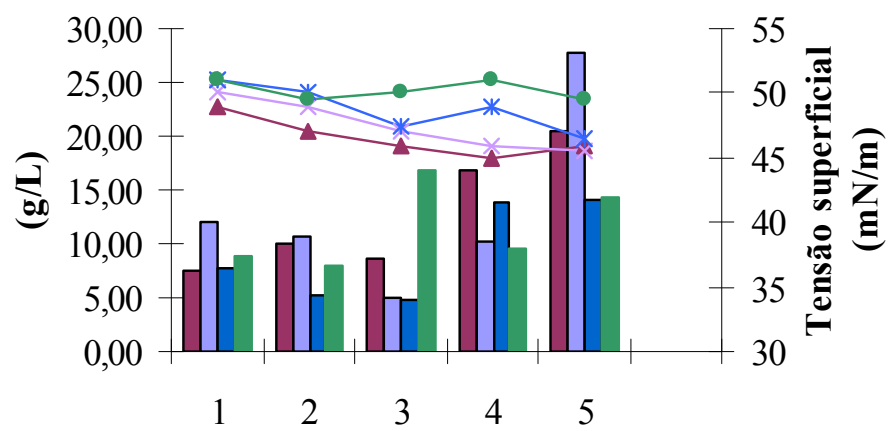

Concentração de Vinhaça (\%)

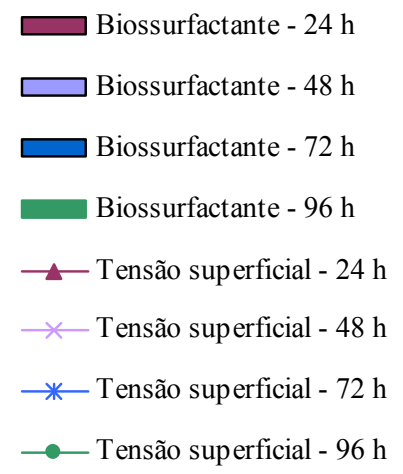

Figura 21. Relação da produção de biossurfactante e da tensão superficial durante a fermentação de 24, 48, 72 e 96 horas nas diferentes concentrações de vinhaça utilizadas por Bacillus pumilus incubada a $30^{\circ} \mathrm{C}$ e $200 \mathrm{rpm}$. 
$\mathrm{Na}$ fermentação com o substrato óleo residual de fritura pode-se observar na Figura 22 uma maior produção de biossurfactante na concentração de 5 e $3 \%$ em 96 horas de fermentação, 5,7 g/L e 5,21 g/L, respectivamente. Este resultado é melhor que o encontrado por Haba e colaboradores (2000) que utilizando 2 e $4 \%$ de óleo residual de fritura obtiveram uma produção de $1,4 \mathrm{~g} / \mathrm{L}$ de um biossurfactante produzido por Pseudomonas spp.

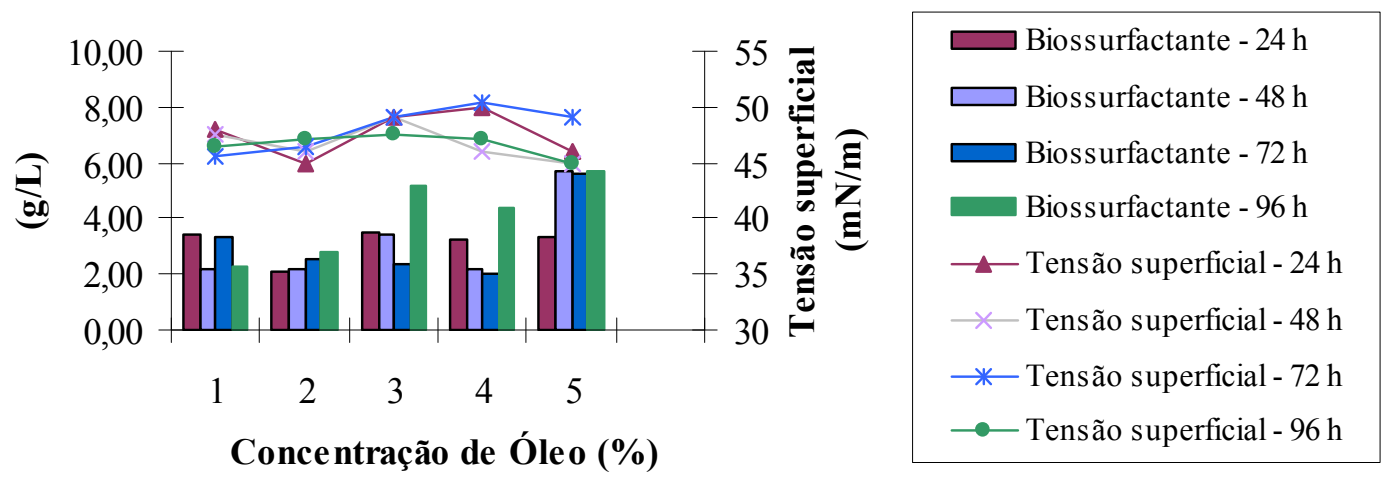

Figura 22. Relação da produção de biossurfactante e da tensão superficial durante a fermentação de 24, 48, 72 e 96 horas nas diferentes concentrações de óleo residual de fritura utilizadas por Bacillus pumilus incubada a $30{ }^{\circ} \mathrm{C}$ e $200 \mathrm{rpm}$.

Na Figura 23 está expresso o resultado para o substrato melaço, a maior produção foi na concentração de $5 \%$ em 48 horas de fermentação $(27 \mathrm{~g} / \mathrm{L})$. Esta mesma concentração também foi encontrada por Joshi e colaboradores (2008) para maior produção de biossurfactante em 72 horas por Bacillus subtilis $(26,20 \mathrm{~g} / \mathrm{L})$.

Nas fermentações onde foi observada maior produção de biossurfactante também foi observada maior redução da tensão superficial, porém o mesmo não ocorreu em todas as concentrações. Alguns autores também relatam que nem sempre os menores valores de tensão superficial foram os maiores valores da concentração de biossurfactante presente no meio indicando a importância de quantificar a produção em cada concentração de substrato e em cada período de fermentação testado (GOLVEIA et al., 2003).

Os resultados demonstraram que o período de fermentação para ocorrer maior produção de biossurfactante foi diferente entre as concentrações testadas em todos os 
substratos, este fato sugere que a produção foi diretamente influenciada pela composição, concentração dos componentes do meio e variação do $\mathrm{pH}$, o que indica que o microrganismo se comportou de forma diferente em cada condição testada. Algumas concentrações tiveram a melhor produção em 96 horas de fermentação, talvez porque neste tempo ocorreu uma escassez de alguns nutrientes essenciais desencadeando a produção de metabólitos secundários (OCHI, 2007).

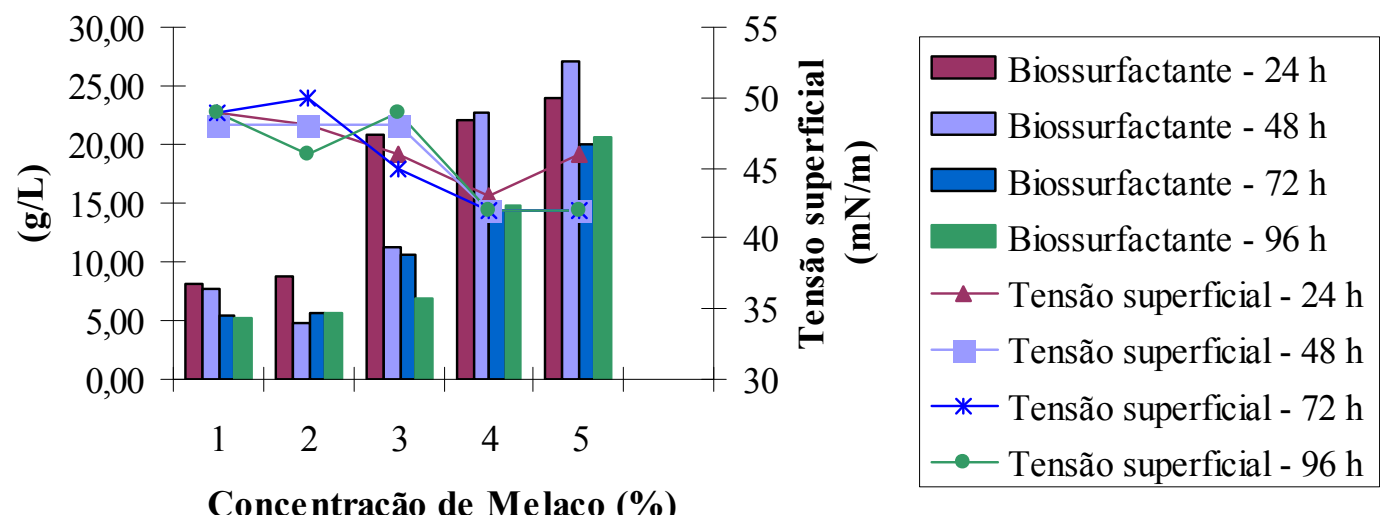

Figura 23. Relação da produção de biossurfactante e da tensão superficial durante a fermentação de 24, 48, 72 e 96 horas nas diferentes concentrações melaço utilizadas por Bacillus pumilus incubada a $30^{\circ} \mathrm{C}$ e $200 \mathrm{rpm}$.

\subsection{Determinação da biomassa}

A biomassa foi relacionada com a massa celular seca utilizando uma curva de calibração previamente determinada.

Nos resultados encontrados a biomassa não está diretamente relacionada com a produção de biossurfactante em todos os substratos (Figuras 24, 25, 26, 27 e 28). Este mesmo resultado é similar ao encontrado por Ubeda (2004), em estudos com Kocuria rhizophila no qual a produção de biossurfactante aconteceu independente do crescimento celular em meio contendo óleo de soja; e por Nitschke e Pastore (2006) utilizando Bacillus subtilis utilizando manipueira como substrato. 
Verifica-se que para cada concentração houve um crescimento celular diferente, e que nas condições onde foi encontrada maior produção a biomassa foi baixa. Este mesmo resultado foi encontrado por Sobrinho e colaboradores (2008) utilizando a levedura Candida sphaerica. Isto pode ter ocorrido pela influência das diferentes concentrações do substrato, $\mathrm{pH}$ e componentes do meio que podem ter provocado no microrganismo um mecanismo de defesa fazendo aumentar ou inibir a concentração de biossurfactante, além de poder levar à produção de outros compostos que não o esperado.

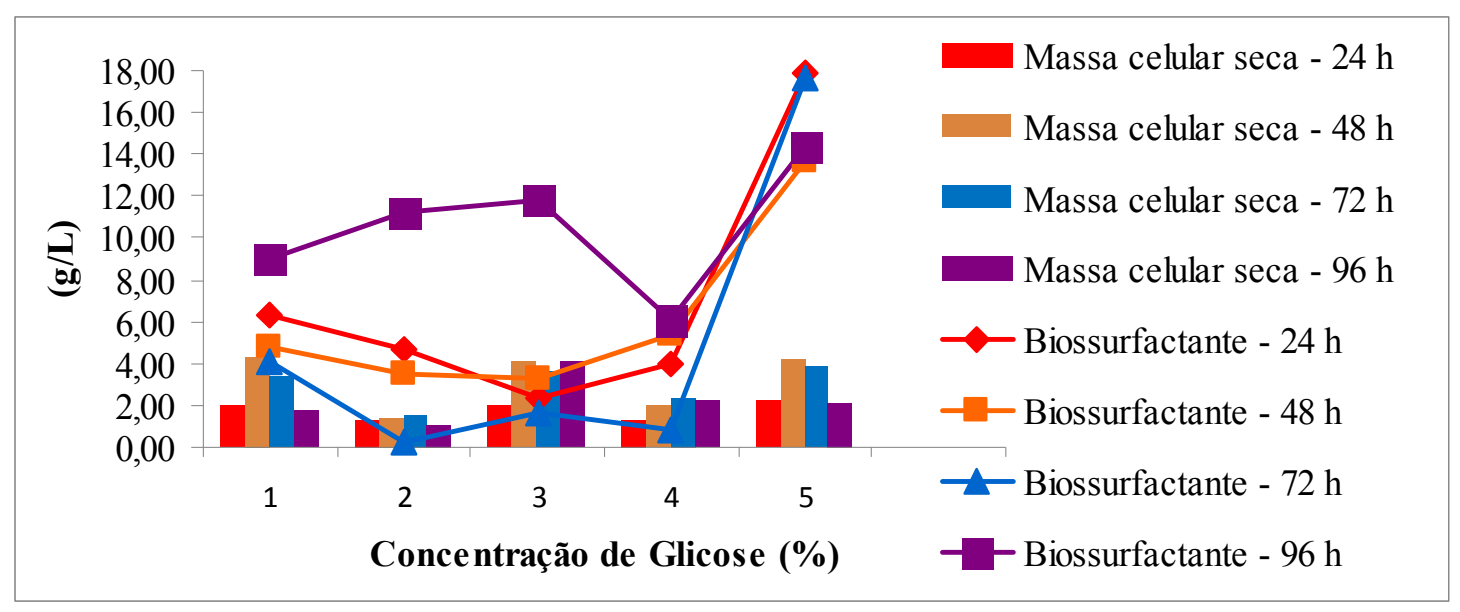

Figura 24. Relação entre a produção de biossurfactante e massa celular seca durante os períodos de fermentação de 24, 48, 72 e 96 horas nas diferentes concentrações de glicose utilizadas por Bacillus pumilus incubada a $30^{\circ} \mathrm{C}$ e $200 \mathrm{rpm}$. 


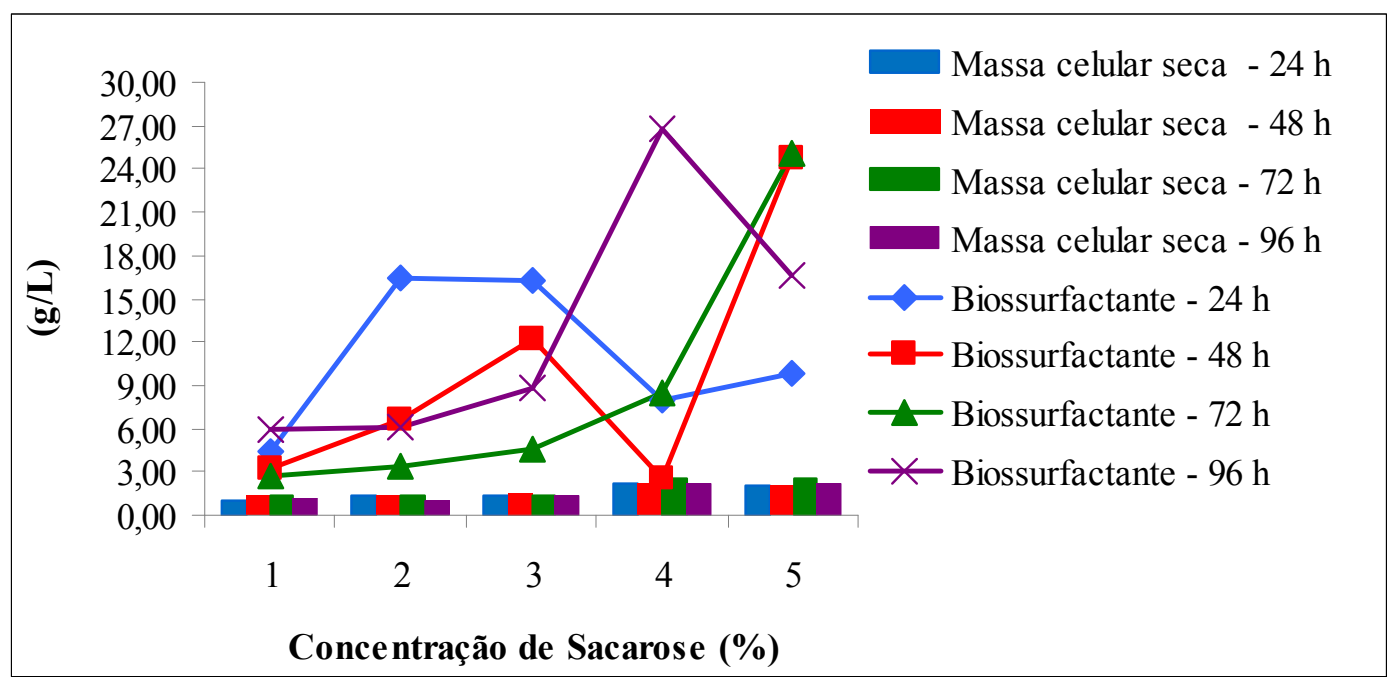

Figura 25. Relação entre a produção de biossurfactante e a massa celular seca durante os períodos de fermentação de 24, 48, 72 e 96 horas nas diferentes concentrações de sacarose utilizadas por Bacillus pumilus incubada a $30^{\circ} \mathrm{C}$ e $200 \mathrm{rpm}$.

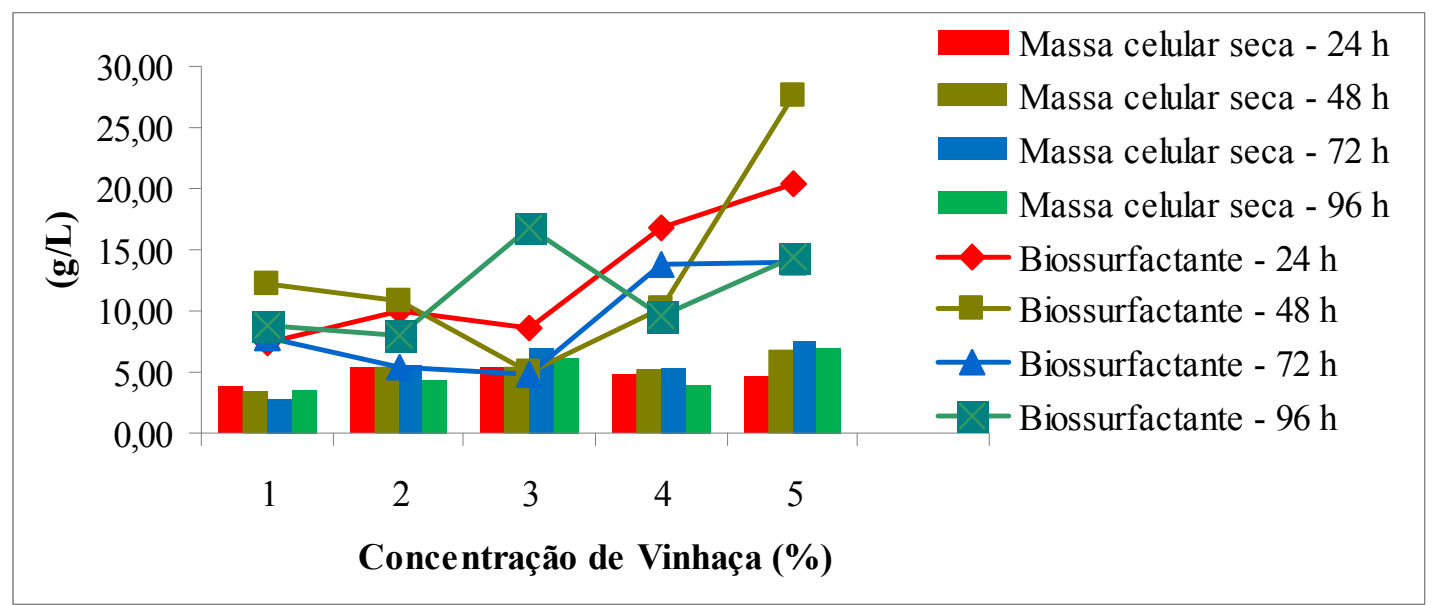

Figura 26. Relação entre a produção de biossurfactante e a massa celular seca durante os períodos de fermentação de 24, 48, 72 e 96 horas nas diferentes concentrações de vinhaça utilizadas por Bacillus pumilus incubada a $30^{\circ} \mathrm{C}$ e $200 \mathrm{rpm}$. 


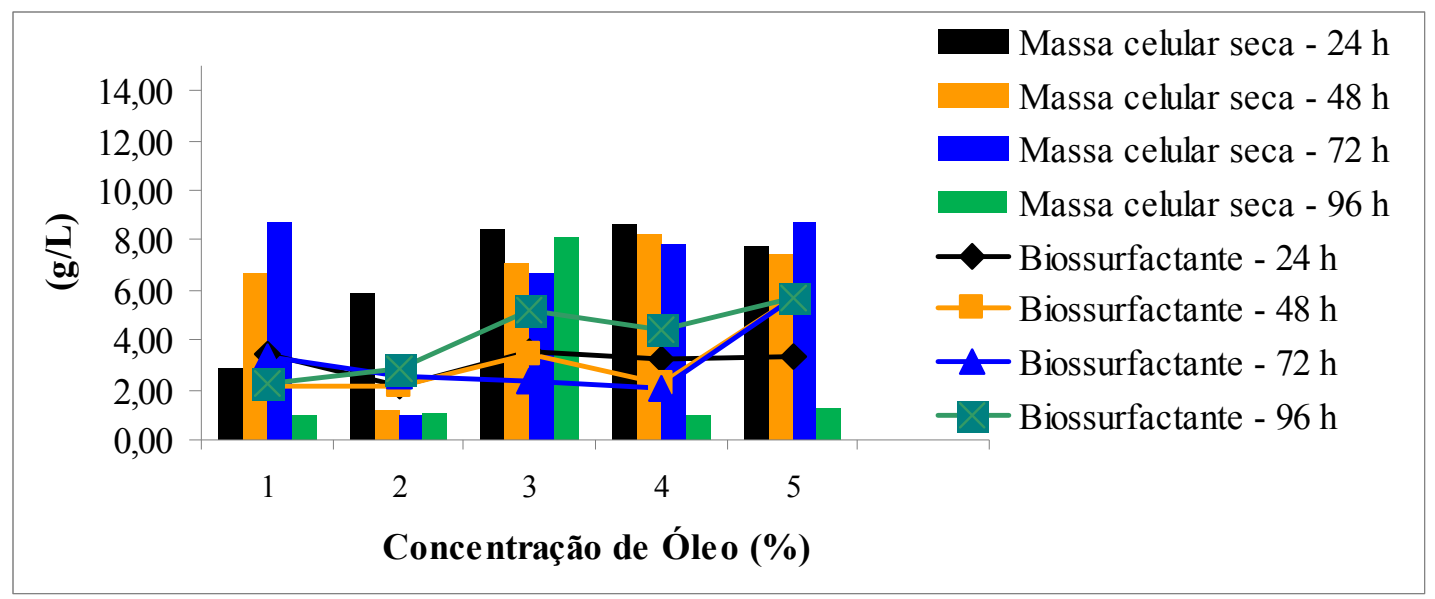

Figura 27. Relação entre a produção de biossurfactante e a massa celular seca durante os períodos de fermentação de 24, 48, 72 e 96 horas nas diferentes concentrações de óleo residual de fritura utilizadas por Bacillus pumilus incubada a $30{ }^{\circ} \mathrm{C}$ e $200 \mathrm{rpm}$.

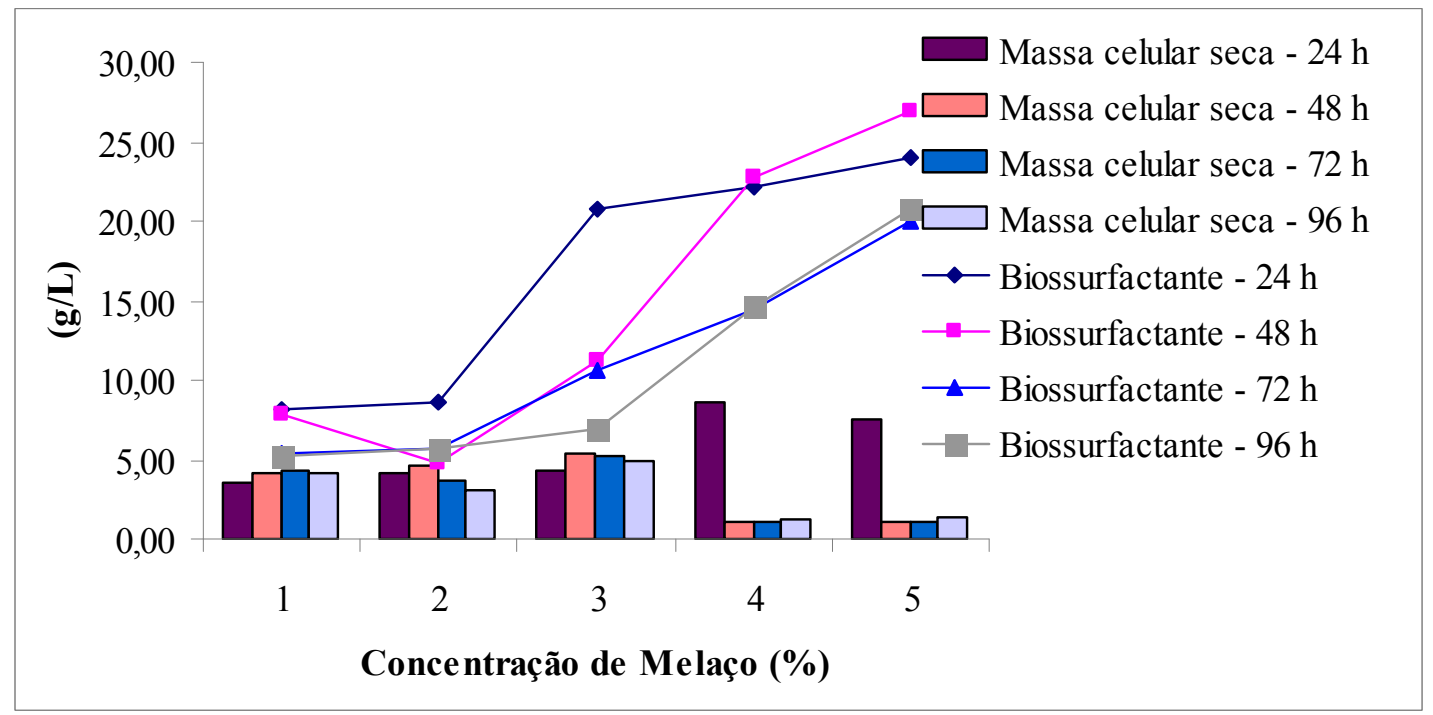

Figura 28. Relação entre a produção de biossurfactante e a massa celular seca durante os períodos de fermentação de 24, 48, 72 e 96 horas nas diferentes concentrações de melaço utilizadas por Bacillus pumilus incubada a $30^{\circ} \mathrm{C}$ e $200 \mathrm{rpm}$. 


\subsection{Determinação da atividade emulsificante}

Para a determinação da atividade emulsificante foi escolhida a sacarose porque o biossurfactante produzido utilizando este substrato foi um bom redutor da tensão superficial. Foi utilizado o caldo livre de células com tolueno na proporção 3,5:2 e esta mistura foi agitada por 2 minutos e lida em espectrofotômetro a $620 \mathrm{~nm}$.

$\mathrm{Na}$ Tabela 9 estão os resultados obtidos. De acordo com esta é possível verificar que o maior e menor valor de atividade emulsificante encontrado foi proporcional à maior e menor produção de biossurfactante, $26,83 \mathrm{~g} / \mathrm{L}$ e 2,51 g/L, respectivamente.

Quanto maior a densidade ótica maior é a atividade emulsificante. Lang (2002) realizou um trabalho no qual o emulsan atingiu um valor de atividade emulsificante de 2,44 a $600 \mathrm{~nm}$. Neste trabalho foi encontrado resultado superior $(2,70)$ inferindo ter o biossurfactante produzido uma boa atividade emulsificante.

Tabela 9. Determinação da atividade emulsificante no sobrenadante livre de células a 620 nm nos períodos de fermentação de 24, 48, 72 e 96 horas nas diferentes concentrações de sacarose utilizadas por Bacillus pumilus incubada a $30{ }^{\circ} \mathrm{C}$ e $200 \mathrm{rpm}$.

\begin{tabular}{crrrr}
\hline \multicolumn{7}{c}{ Sacarose } \\
\hline Concentração (\%) & $\mathbf{2 4} \mathbf{h}$ & $\mathbf{4 8} \mathbf{h}$ & $\mathbf{7 2} \mathbf{~}$ & $\mathbf{9 6} \mathbf{~}$ \\
\hline $\mathbf{1}$ & 1,56 & 1,70 & 1,75 & 1,93 \\
$\mathbf{2}$ & 1,90 & 1,90 & 2,50 & 2,05 \\
$\mathbf{3}$ & 2,46 & 1,66 & 2,25 & 2,30 \\
$\mathbf{4}$ & 1,95 & 1,43 & 2,00 & 2,70 \\
$\mathbf{5}$ & 2,20 & 1,65 & 2,55 & 2,24 \\
\hline
\end{tabular}

\subsection{Determinação da atividade antimicrobiana}

A partir dos parâmetros de produção analisados, o biossurfactante produzido pelo substrato sacarose foi escolhido para o teste antimicrobiano porque este apresentou a maior redução da tensão superficial $\left(32 \mathrm{mNm}^{-1}\right)$. Os ensaios foram realizados seguindo o método de disco difusão (item 4.4.6). Foi analisada a capacidade de inibição frente às bactérias: Bacillus subtilis, Bacillus cereus, Staphylococcus aureus, Bacillus thuringiensis, Salmonella enteritidis, Zymomonas mobilis, Azotobacter vinelandi, 
Escherichia coli; e contra as leveduras: Rhodotorula rubra, Candida tropicalis, Sporobolomyces roseus.

Neste trabalho nenhum halo de inibição foi observado em todos os microrganismos testados indicando que o biossurfactante produzido não possui atividade antimicrobiana sobre estes. Este resultado obtido contrasta com os resultados observados por Cao e colaboradores (2009), no qual o biossurfactante produzido por Bacillus natoo TK-1 apresentou atividade antibacteriana e antifúngica.

$\mathrm{O}$ fato do biossurfactante obtido nesse trabalho não apresentar atividade antimicrobiana pode estar associado com o grau de pureza deste, uma vez que, foi testado o composto bruto podendo haver algum fator limitante na ação do tenso-ativo. Outra possível explicação pode estar relacionado ao grau de difusão do tenso-ativo no meio de cultura, podendo ter sido baixo impedindo a formação de um halo de inibição pelos microrganismos testados.

\subsection{Avaliação do potencial para biorremediação}

O potencial para biorremediação foi avaliado mediante a degradação do óleo residual de fritura (item 4.4.10). Neste experimento foi utilizado o sobrenadante proveniente da fermentação com sacarose no melhor parâmetro de produção, 4\% em 96 horas, onde foi observada a maior redução da tensão superficial e uma produção elevada de biossurfactante $(26,83 \mathrm{~g} / \mathrm{L})$.

A Figura 29 mostra a análise macroscópica realizada com o sobrenadante para remoção do óleo residual de fritura da areia. É possível observar que existe um potencial para remoção do óleo residual de fritura da areia, uma vez que, o material demonstrou fluidez após 24 horas escorrendo o óleo pela placa de petri. Resultado semelhante foi encontrado por Whang e colaboradores (2008) para remoção de óleo diesel de areia utilizando o biossurfactante produzido por Bacillus subtilis. 

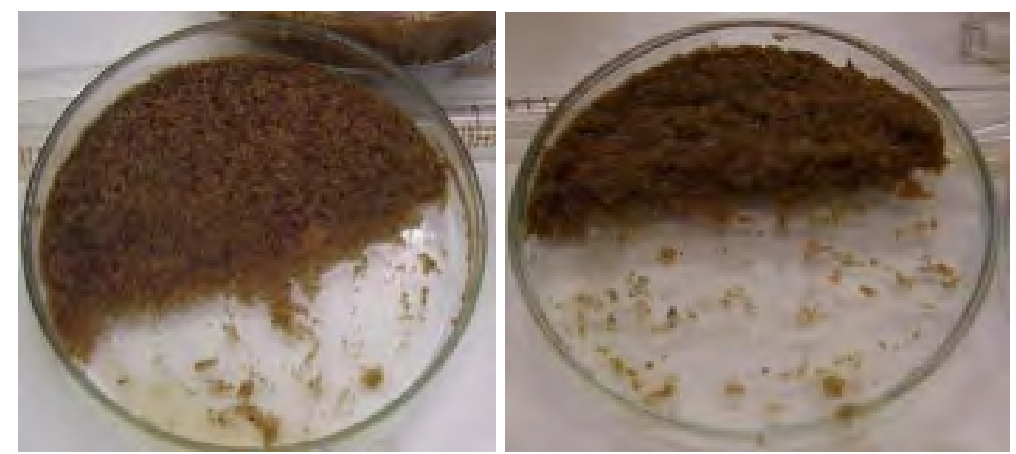

Figura 29. Análise macroscópica do potencial de degradação do óleo residual de fritura na presença do caldo fermentado livre de células proveniente da fermentação com sacarose na concentração de $4 \%$ em 96 horas pela bactéria Bacillus pumilus a $30{ }^{\circ} \mathrm{C}$ em $200 \mathrm{rpm}$.

Foram realizadas as diluições 1:2, 1:3, 1:4 e 1:5, até a diluição 1:3 foi observada degradação do óleo residual presente na areia, nas demais concentrações o óleo permaneceu preso à areia indicando não haver remoção.

$\mathrm{Na}$ remoção do óleo residual de fritura da água não foi observado macroscopicamente nenhum resultado permanecendo a coluna de óleo sobre a água em todas as condições testadas, este resultado contrasta o encontrado por Whang e colaboradores em 2008.

Segundo Pirôllo (2006), a biodegradação é um processo complexo que depende da natureza e da quantidade de óleo ou hidrocarbonetos presentes, além disso, o crescimento de microrganismos sobre óleos é um problema, pois estes são imiscíveis em água. Neste trabalho não foi observado nenhum resultado visível quando utilizado o inóculo bacteriano nas misturas areia-óleo e água-óleo, talvez porque nas condições do experimento a bactéria Bacillus pumilus não encontrou condições adequadas para degradar o substrato. 


\section{CONCLUSÕES}

A bactéria Bacillus pumilus demonstrou ser um microrganismo capaz de produzir biossurfactante utilizando glicose, sacarose, vinhaça, óleo residual de fritura e melaço como fontes de carbono.

A produção de biossurfactante foi diferente em cada substrato e concentração testada. A maior produção de biossurfactante $(26,83 \mathrm{~g} / \mathrm{L})$ ocorreu utilizando o substrato sacarose onde também foi observada a maior redução da tensão superficial $\left(32 \mathrm{mNm}^{-1}\right)$. O melhor parâmetro de produção foi na concentração de 4\% em 96 horas de incubação, porém, em concentrações menores obteve-se uma quantidade relativamente alta de biossurfactante em um curto período de tempo $(16,4 \mathrm{~g} / \mathrm{L}$, na concentração de $2 \%$ em 24 horas de fermentação).

O biossurfactante produzido com todos os substratos demonstrou ser eficiente, uma vez que, foi capaz de reduzir a tensão superficial e apresentou baixos valores de CMC (menores que $2 \mathrm{~g} / \mathrm{L}$ ).

Dos substratos testados, apenas sacarose e melaço produziram um biossurfactante capaz de formar emulsões estáveis.

O biossurfactante obtido com sacarose não apresentou atividade antimicrobiana frente aos microrganismos testados.

O biossurfactante produzido pela bactéria Bacillus pumilus mostrou potencial para aplicação em desastres ecológicos. 


\section{REFERÊNCIAS BIBLIOGRÁFICAS}

ABRAHAM, W. R. Novel glycine containing glucolipids from thealkane using bacterium Alcanivorax borkumensis. Biochimistry and Biophysical Acta, v.1393, p.57-62, 1998.

AGRIANUAL Anuário da agricultura brasileira. São Paulo: FNP, 2004.

ALY, S. M.; ABD-EL-RAHMAN, A. M,; JOHN, G.; MOHAMED, M. F. Characterization of some bacteria isolated from oreochromis niloticus and their potential use as probiotics. Aquaculture, v. 277, p. 1-6, 2008.

AOYAMA, M.; YASUDA, M; K.; KOBAMOTO, N.; OKU, H.; KATO, F. Soybean-milkcoagulating activity of Bacillus pumilus derives from a serine proteinase. Applied Microbiology and Biotechnology, v.53, p. 390-395, 2000.

ARAGÃO, V. O.; ROCHA, L. L.; ANJELINA, A. L.; PAES F. A.; HISSA , D. C.; PINTO, N. W.; MELO, V. M. M. M.; MARTINS, S. C. S.; Leveduras degradadoras de hidrocarbonetos e produtoras de biossurfactantes. In Reunião anual da SBPC. 57, ANAIS... FORTALEZA: SBPC, 2007.

ARIMA, K. KAKINUMA, A.; TAMURA, G. Biochemistry Biophysical Research Commun, v.31, p.488, 1968.

ASFÇE, Y.; NURBASF, M.; AÇEKEL, Y. S. Removal of zinc ions from a soil component Na-feldspar by a rhamnolipid biosurfactant. Desalination, v.223, p.361-365, 2008.

ASHA, A.; JUWARKAR; NAIR, A.; DUBEY, K. V.; SINGH, S. K.; DEVOTTA, S. Biosurfactant technology for remediation of cadmium and lead contaminated soils. Chemosphere, n. 68, p. 1996-2002, 2007.

ATLAS, R. M. Bioremediation of petroleum pollutants. Int. Biodeterior. Biodegrad Oxford, v.35, n.1-3, p.317-327, 1995. 
AYOTAMUNO, J. M.; KOGHARA, R. B.; TALEAT, M. O. Bioremediation of a petroleum hydrocarbon polluted agricultural soil at different levels of water application in Port Harcourt, Nigeria. Journal of Food and Agrícola Environmental, v. 4, p. 214-217, 2006.

BANAT. I M.; MAKKAR R. S.; CAMEOTRA, S. S. Microbial production of surfactants and their commercial potential. Applied Microbiology and Biotechnology, v. 53, p. 495$508,2000$.

BARBOSA, M. M. C.; PAZ, M. C. F. Produção de biossurfactantes por Chromobacterium violaceum utilizando como substrato óleo vegetal (óleo de pequi). II Congresso de Pesquisa e Inovação da Rede Norte Nordeste de Educação Tecnológica João Pessoa - PB 2007.

BARROS, F. F. C.; QUADROS, C. P.; MARÓSTICA-JÚNIOR, M. R.; PASTORE, G. M. Surfactina: Propriedades químicas, tecnológicas e funcionais, para aplicação em alimentos. Química Nova, v. 30, p. 409-414, 2007.

BATISTA, S. B.; MOUNTEER, A. H.; AMORIM, F.R; TÓTOLA, M. R. Isolation and characterization of biosurfactant/bioemulsifier-producing bacteria from petroleum contaminated sites. Water Science and Technology, v. 34, p. 187-194, 2006.

BEDNARSKI, W.; ADAMCZAK, M.; TOMASIK, J.; PLASZCZIK, M. Application of oil refinery waste in the biosynthesis of glycolipids by yeast. Bioresource Technology, v.95, p.15-18, 2004.

BENTO, F. M.; CAMARGO, F. A. O.; OKEKE, B. Bioremediation of soil contaminated by diesel oil. Brazilian Journal of Microbiology, v.34, p.65-68, 2003.

BICCA, F. C.; FLECK, L. C.; AYUB, M. A. Z. Production of biosurfactant by hydrocarbon degrading Rhodococcus ruber and Rhodococcus erythropolis. Revista de Microbiologia, v.30, p.231-236, 1999. 
BOGNOLO, G. Colloids and Surfactants, v. 152, p. 41-52, 1999.

BOUCHEZ, N. M.; RAKATOZAFY, H.; MARCHAL, R.; LEVEAU, J. Y.; VANDECASTEELE. Journal Applied Microbiology, v. 86, p. 421-428, 1999.

BRINT, J. M.; OHMAN, D. E. Synthesis of multiple exoproducts in Pseudomonas aeruginosa is under the control of RhlR-RhlI, another set of regulators in strain PAO1 with homology to the autoinducer-responsive LuxR-LuxI family. Journal of Bacteriology, v.177, p.7155-7163, 1995.

BROPHY, P. F.; KNOOP, F. C. Bacillus pumilus in the induction of clindamycinassociated enterocolitis in guinea pigs. Infect Immunology, v, 35, p.289-95, 1982.

BUENO, S. M. Bactérias produtoras de biossurfactantes: isolamento, produção, caracterização e comportamento num sistema modelo. Tese (doutorado em engenharia e ciência de alimentos), Universidade Estadual Paulista “Julio de Mesquita Filho", São José do Rio Preto - SP, 86 f, 2008.

CALVO, C.; MANZANERA, M.; SILVA-CASTRO, G. A.; UAD, I.; GONZÁLEZLÓPEZ, J. Application of bioemulsifiers in soil oil bioremediation processes. Future prospects. Science of the Total Environment, 2008.

CAMARGO, O. A.; VALADARES, J. M. A. S.; BERTON, R. S.; TEÓFILO SOBRINHO, J.; MENK, J. R. F. Alteração de características químicas de um latossolo vermelho-escuro distrófico pela aplicação de vinhaça. Boletim Científico do Instituto Agronômico de Campinas, Campinas, v.9, p. 23, 1987.

CAO, X. H.; LIAO, Z.Y.; WANG, C. L.; YANG, W. Y.; LU, M. F. Evaluation of a lipopeptide biosurfactant from Bacillus natto TK-1 as a potencial source of anti-adhesive, antimicrobial and antitumor activities. Brazilian Journal of Microbiology, v. 40, p. 373$379,2009$. 
CHAKRABARTY, A. M. Genetically manipulated microorganisms and their products in the oil service industries. Trends in Biotechnology, v.3, p.32-36, 1985.

CHO, K. M.; MATH, R. K.; HONG, S. Y.; ISLAM, S. A.; MANDANNA, D. K.; CHO, J. J.; YUN, M. G.; KIM, J. M.; YUN, H. D. Iturin produced by Bacillus pumilus HY1 from Korean soybean sauce (kanjang) inhibits growth of aflatoxin producing fungi. Food Control, v. 20, p. 402-406, 2009.

CHRISTOFI, N.; IVSHINA, I. B. Microbial surfactants and their use in field estudies of soil remediation. Journal of Applied Microbiology, v. 93, p.915-929, 2002.

CHU, W.; CHAN, K. The mechanism of the surfactant aided washing for hydrophobic soil and partial hydrophobic organics. Science Environmental, v. 307, p. 83-92, 2003.

CORAZZA, R. I. Reflexões sobre o papel das políticas ambientais de ciência e tecnologia na modelagem de opções produtivas 'mais limpas' numa perspectiva evolucionista: um estudo sobre o problema da disposição da vinhaça. In: III Encontro Nacional da Sociedade Brasileira de Economia Ecológica, Recife, 1999.

CORTEZ, L.; MAGALHÃES, P.; HAPPI, J. Principais subprodutos da agroindústria canavieira e sua valorização. Revista Brasileira de Energia, v.2, 1992.

CZAPLICKA, M.; CHMIELARZ, A. Application of biosurfactants and non-ionic surfactants for removal of organic matter from metallurgical lead-bearing slime. Journal of Hazardous Materials, v. 163, p. 645-649, 2009.

DAVEREY, A.; PAKSHIRAJAN, K. Production of sophorolipids by the yeast Candida bombicola using simple and low cost fermentative media, Food Research International, p. 1-6, 2009.

DELEU, M.; PAQUOT, M. From renewable vegetables resourcesto microorganisms: new trends in surfactants. Comptes Rendus Chimie, n. 7, p. 641-646, 2004. 
DESAI, J.D.; BANAT, I.M. Microbal production of surfactants and their commercial potential. Microbiol. Molecular Biological, v. 61, p. 47-64. 1997.

DWARAKANATH, V.; KOSTARELOS, K.; POPE, G. A.; SHOTTS, D.; WADE, W. H. Anionique surfactant remediation of contaminated soil columns by nonaqueous phase liquids. Journal Contaminant Hydrology, v. 38, p. 465-488, 1999.

FERNANDES, P. A. V.; ARRUDA, I. R.; SANTOS, A. F. A. B.; ARAÚJO, A. A.; MAIOR, A. M. S. M.; XIMENES, E. A. Antimicrobial activity of surfactants produced by bacillus subtilis r14 against multidrug-resistant bacteria. Brazilian Journal of Microbiology, v.38, p. 704-709, 2007.

FERRAZ, C. A. M.; AQUARONE, E.; KRAUTER, M.; BALLONI, W.; FLORENZANO, G. Utilização de sub-produtos da indústria alcooleira na obtenção de biomassa de Spirulina maxima. Parte II. Emprego do resíduo da destilação do mosto fermentado (vinhaça). Revista de Microbiologia, São Paulo, n. 17, p. 15-25, 1986.

FERREIRA, L. C. Aspectos microbiológicos da conservação de polpas de pequi (Caryocar brasiliense Camb.): Qualidade, higiene, adaptação de bactérias ao estresse ácido e isolamento de microrganismos com potencial para bioconservação. Tese (doutorado), Universidade Federal de Minas Gerais, Faculdade de Farmácia, MG, 110 f, 2007.

FIECHTER, A. Biosurfactants: moving towards industrial application. Trends Biotechnology, v. 10, p. 208-217, 1992.

FIRESTONE, D.; STIER, R. F.; BLUMENTHAL, M. M. Regulation of frying fats and oils. Food Technology, v. 45, n. 2, p. 90-94, 1991.

FOX, S. L.; BALA, G. A. Production of surfactant from Bacillus subtilis ATCC 21332 using potato substrates. Bioresource Technology, v. 75, p. 235-240, 2000.

FUKUOKA, T.; MORITA, T.; KONISHI, M.; IMURA, T.; KITAMOTO, D. A basidiomycetous yeast, Pseudozyma tsukubaensis, efficiently produces a novel glycolipid 
biosurfactant. The identification of a new diastereomer of mannosylerythritol lipid-B. Carbohydrate Research, v.343, p.555-560, 2008.

GEORGIOU, G.; LIN, S. C.; SHARMA, M. M. Surface-Active compounds from microorganisms. Biotechnology, v. 10, p. 60-65, 1992.

GOLVEIA, E. R.; LIMA, D. P. A.; DUARTE, M. S.; LIMA, G. M. S.; ARAÚJO, J. M. Bactérias produtoras de biossurfactantes- produção de biossurfactantes por bactérias isoladas de poços de petróleo. Biotecnologia Ciência e Desenvolvimento, n.30, p.39-45, 2003.

GHOJAVAND, H.; VAHABZDEH, F.; ROAYAEI, E.; SHAHRAKI, A. K. Production and properties of a biosurfactant obtained from a member of the Bacillus subtilis group (PTCC 1696). Journal of Colloid and Interface Science, v. 324, p. 172-176, 2008.

GONÇALVES, C. A. S.; SILVA, E. L. Tratamento Físico-Químico da Vinhaça. In: XXVII Congresso interamericano de engenharia sanitária e ambiental. Associação Brasileira de Engenharia Sanitária e Ambiental - abes. Fortaleza-CE, Brasil, 2000.

HABA, E.; ESPUNY, M. J.; BUSQUETS, M.; MANRESA, A. Screening and production of rhamnolipids by Pseudomonas aeruginosa 47T2 NCIB 40044 from waste frying oils. Journal of Applied Microbiology, v.88, p. 379-387, 2000.

HELVACI, S. S.; PECKER, S.; O“ ZDEMIR, G. Effect of electrolytes on the surface behavior of rhamnolipids R1 and R2. Colloids Surface, n. 35, p. 225- 233, 2004.

HOLMBERG, K. Natural Surfactants. Current Opinion in Colloid \& Interface Science, v. 6, p. 148-159, 2001.

HOMMEL, R. K. Formation and physiological role of biosurfactants produced by hydrocarbon-utilizing microorganisms. Biodegradation, v.1, p.107-119, 1990. 
HOULT, B.; TUXFORD, A. F. Toxin production by Bacillus pumilus. Journal Clinical Pathology, n. 44, p. 455-458, 1991.

HUA, Z.; CHEN, J.; LUN, S.; WANG, X. Influence of biosurfactants produced by Candida Antarctica on surface properties of microorganism and biodegradation of $\mathrm{n}$ alkanes. Water Research, n. 37, p. 4143-4150, 2003.

IQBAL, S.; KHALID, Z. M.; MALIK, K. A. Enhanced biodegradation and emulsification of crude oil and hyperproduction of biosurfactants by gamma ray-induced mutant of Pseudomonas aeruginosa. Journal of Applied Microbiology, v.21, p.176-179, 1995.

IRIE, Y.; OTOLLE, G. A.; YUK, M. H. Pseudomonas aeruginosa rhamnolipids disperse Bordetella bronchiseptica biofilms. Microbiology Letters, v.250, p. 237-243, 2005.

JOO, H. J.; NDEGWA, P. M.; SHODA, M.; PHAE, C. G.; Bioremediation of oilcontaminated soil using Candida catenulate and food waste. Environmental Pollution, n. 156, p. 891-896, 2008.

JOSHI, S.; BHARUCHA, C.; DESAI, A.J. Production of biosurfactant and antifungal compound by fermented food isolate Bacillus subtilis 20B. Bioresource Technology, v.30, p. 1010-1016, 2007.

JOSHI, S.; BHARUCHA, C.; JHA, S.; YADAV, S.; NERURKAR, A.; DESAI, A. J. Biosurfactant production using molasses and whey under thermophilic conditions. Bioresource Technology, n. 99, p. 195-199, 2008.

KALOGIANNIS， S.; IAKOVIDOU， G.; LIAKOPOULOU-KYRIAKIDES， M.; KYRIAKIDIS, D. A.; SKARACIS, G. N. Optimization of xanthan gum production by Xanthomonas campestris grown in molasses. Process Biochemistry, v.39, p.249-256, 2003.

KEAMS, D. B.; LOSICK, R. Swarming motility in undomesticated Bacillus subtilis Molecular Microbiology, v. 49, p. 581-590, 2003. 
KHALLADI, R.; BENHABILES, O.; BENTAHAR, F.; MOSTEFA, N. M. Surfactant remediation of diesel fuel polluted soil. Journal of Hazardous Material, v. 164, p.1179$1184,2009$.

KIRAN, G. S.; HEMA, T. A.; GANDHIMATHI, R.; SELVIN, J.; MANILAL, A.; SUJITH, S.; NATARAJASEENIVASAN, K. Optimization and production of a biosurfactant from the sponge-associated marine fungus Aspergillus ustus MSF3. Revista Colloids and Surfaces, v.10, 2009.

KIRAN, G. S.; THOMAS, T. A.; SELVIN, J.; SABARATHNAM, B.; LIPTON, A. P. Optimization ande characterization of a new lipopeptide biosurfactant produced by marine Brevibacterium aureum MSA13 in solid state culture. Bioresource Technology, v.101, p.2389-2396, 2010.

KOCH, A. K.; KAPPELI, O.; FIECHTER, A.; REISER, Journal Bacteriology, n. 173, p. 4212-4219, 1991.

LANG, S. Biological Amphiphiles (Microbiol Biosurfactants). Current Opinion in Colloid \& Interface Science, v.7, p. 12-20, 2002.

LAZARIDOU, A.; ROUKAS, T.; BILIADERIS, C. G.; VAIKOUSI, H. Characterization of pullulan produced from beet molasses by Aureobasidium pullulans in a stirred tank reactor under varying agitation. Enzyme Microbiology and Technology, v.31, p.122-132, 2002.

LEE, D. H.; CODY, R. D.; KIM, D. J.; CHOI, S. Effect of soil texture on surfactant-based hydrophobic organic remediation of contaminated soil. Environmental International, v.27, p. 681-688, 2002.

LEE, S. C.; LEE, S. J.; KIM, S. H.; P, I. H.; LEE, Y. S.; CHUNG, S. Y.; CHOI, Y. L. Characterization of new biosurfactant produced by Klebsiella sp.Y6-1 isolated from waste soybean oil. Bioresource Technology, p.2288-2292, 2008. 
LIMA, C. J. B. Produção de biossurfactante por Pseudomonas aeruginosa empregando óleo de soja residual. Tese (doutorado em engenharia química) - Universidade Federal de Uberlândia, MG, 190 f, 2007.

LIN, S. C. Biosurfactants: Recent Advances. Journal Chemistry Technology and Biotechnology, v. 66, p. 66, 109-120, 1996.

MAKKAR, R.; CAMEOTRA, S. Utilization of molasses for biosurfactant production by two Bacillus strains at thermophilic conditions. Journal Am. Oil Chemistry, Soc. 74, p.887-889, 1997.

MANEERAT, S. Biosurfactants from marine microorganisms. Songklanakarin Journal Science the Technology, 27(6): p.1263-1272, 2005.

MARÇAL, M. Produção de biopolímeros por Candida lipolytica em meios suplementados por óleos vegetais (babaçu, côco e dendê). Dissertação (mestrado em nutrição) Universidade Federal de Pernambuco, Recife, 147 f, 1991.

MINHONI, M. T. A.; CERRI, C. C. Decomposição de vinhaça em solo sob diferentes níveis de umidade: liberação de $\mathrm{CO}_{2}$, formação de biomassa microbiana e imobilização do nitrogênio adicionado. Revista Brasileira de Ciência do Solo, Campinas, v.11, p. 25-30, 1987.

MORITA, T.; KONISHI, M.; FUKUOKA, T.; IMURA, T.; KITAMOTO, D. Microbial conversion of glycerol into glycolipid biosurfactants, mannosylerythritol lipids, by a basidiomycete yeast, Pseudozyma antarctica JCM $10317^{T}$. Journal of Bioscience and Bioengineering, v.104, N.1, p. 78-81, 2007.

MULLIGAN, C. N.; YONG, R. N.; GIBBS, B. F. Surfactant-enhanced remediation of contaminated soil: a review. Engineering Geology, v. 60, p. 371-380, 2001.

MULligan, C. N. Environmental applications for biosurfactants. Environmental Pollution, v. 133, p. 183-198, 2005. 
NAYAK, A. S.; VIJAYKUMAR, M. H.; KAREGOUDAR, T. B. Characterization of biosurfactant produced by Pseudoxanthomonas sp. PNK-04 and its application in bioremediation. International Biodeterioration \& Biodegradation, v. 63, p. 73-79, 2009.

NEVES, E.; FORGIARINI, E.; SCHOENHALS, M.; CAMPREGHER, N.; GUZZI, R. Biosurfactants. Environmental. International, v.30, p. 50-62, 2004.

NGUYEN, T. T.; YOUSSEF, N. H.; MCINERNEY, M. J.; SABATINI, D. A. Rhamnolipid biosurfactant mixtures for environmental remediation. Water Research, $\mathrm{n}$. 42, p. $1735-1743,2008$.

NITSCHKE, M.; PASTORE, G. M. Biossurfactantes: propriedades e aplicações. Química Nova, v.25, p.772-776, 2002.

NITSCHKE, M.; PASTORE, G. M. Biosurfactant production by Bacillus subtilis using cassava processing effluent. Applied. Biochemistry and Biotechnology, v.112, p.163$172,2004$.

NISTSCHKE, M.; PASTORE, G. M. Production and properties of a surfactant obtained from Bacillus subtilis grown on cassava wastewater. Bioresource Technology, n. 97, p. 336-341, 2006.

OCHI, K. From microbial differentiation to ribosome engineering. Bioscience, biotechnology, and biochemistry, v. 71, p, 1383-1386, 2007.

ORGENA, M.; JACQUES, P. Bacillus lipopeptides: versatile weapons for plant disease biocontrol.Cel Press, v. 16, p. 115-125, 2007.

ÖZDEMIR, G.; MALAYOGLU, U. Wetting characteristics of aqueous rhamnolipids solutions. Colloids Surface B: Biointerfaces, n. 39, p. 1-7, 2004. 
ÖZDEMIR, G.; PEKER, S.; HELVACI, S. S. Effect of pH on the surface and interfacial behavior of rhamnolipids R1 and R2. Colloids Surface. A: Physicochemistry. Engineering, Aspects, n. 234, p. 135-143, 2004 a.

PARKINSON, M. Bio-surfactants. Biotechnology, n. 3, p. 65-83, 1985.

PATEL, R.; DESAI, A. Biosurfactant production by Pseudomonas aeruginosa GS3 from molasses. Journal of Applied Microbiology, v.25, p.91-94, 1997.

PEYPOUX, F.; BONMATIN, J. M.; WALlACH, J. Applied Microbiology and Biotechnology, v. 51, p.553. 1999.

PIRÔLLO, M. P. S. Estudo da produção de biossurfactantes utilizando hidrocarbonetos. Dissertação (mestrado em ciências biológicas) Universidade Estadual Paulista "Júlio de Mesquita Filho", Rio Claro, SP, 73 f, 2006.

POMSUNTHORNTAWEE, O.; MAKSUNG, S.; HUAYYAI, O.; RUJIRAVANIT, R.; CHAVADEJ, S. Biosurfactant production by Pseudomonas aeruginosa SP4 using sequencing batch reactors: Effects of oil loading rate and cycle time. Bioresource Technology, n. 100, p. 812-818, 2009.

POORNA, C. A.; PREMA, P. Production and partial characterization of endoxilanase Bacillus pumilus using agro industrial residues. Biochemical Engineering Journal, v. 32, p. 106-112, 2006.

QUEIROGA, C. L.; NASCIMENTO , L. R.; SERRA, G. E. Evalutions of paraffins biodegradation and biossurfactant production by bacillus subtilis in the presence of crude oil. Brazilian Journal of Microbiology, v.34, n.4, p.1-10, 2003.

RODRIGUES, L. R.; TEIXEIRA, J. A.; OLIVEIRA, R. Low-cost fermentative medium for biosurfactant production by probiotic bacteria. Bioresource Technology, v.97, p.868$875,2006$. 
ROSENBERG, E. Exploiting microbial growth on hydrocarbon: new markets. Trends Biotechnology, v.11, p.419-424, 1993.

ROSENBERG, E.; RON, E. Z. High and low molecular mass microbial surfactant. Applied. Microbiology and Biotechnology, v. 52, p. 154-162, 1999.

SANTOS, F. K. G.; ALVES, J. V. A.; DANTAS, T. N. C.; DANTAS NETO, A. A.; DUTRA JÚNIOR, T. V.; BARROS NETO, E. L. Determinação da concentração micelar crítica de tensoativos obtidos a partir de óleos vegetais para uso na recuperação avançada de petróleo. IV PDPETRO, Campinas, 2007.

SARUBBO L. A.; MARÇAL, M. C; NEVES M. L .C ; PORTO. A. L . F; CAMPOSTAKAKI, G. M. The use of babassu oil as substrate to produce bioemulsifiers by Candida lipolytica. Canadyan Journal of Microbiology, v.45, p1-4, 1999.

SARUBBO, L. A.; FARIAS, C. B. B.; TAKAKI, G. M. C. Co-Utilization of Canola Oil and Glucose on the Production of a Surfactant by Candida lipolytica. Current Microbiology, v. 54, p. 68-73, 2007.

SINGH, A.; HAMME, J. D. V.; WARD, O. P. Possible food and agricultural applications of microbial surfactants: an assessment. Biosurfactants and biotechnology. Biotechnology Advances, p. 99-121, 2007.

SOBRINHO, H. B. S.; RUFINO, R. D.; LUNA, J. M.; SALGUEIRO, A. A.; CAMPOSTAKAKI, G. M.; LEITE, L. F. C.; SARUBBO. L. A. Utilization of two agroindustrial byproducts for the production of a surfactant by Candida sphaerica UCP0995. Process Biochemistry, n. 43, p. 912-917, 2008.

UBEDA, B. T. Estudo da produção de biossurfactante pela bactéria Kocuria riphozila. Campinas. Dissertação (Mestrado em Engenharia de Alimentos). Universidade de Campinas (UNICAMP), 98 f, 2004. 
VAN DYKI, M. I.; LEE, H.; TREVORS, J. T. Biotechnology and Advance, v. 9, p. 241$245,1991$.

VAN DELDEN, D.; PESCI, E. C; PEARSON, J. P.; IGLEWSKI, B. H. Starvation selection restores elastase and rhamnolipid production in a Pseudomonas aeruginosa quorum-sensing mutant. Infect Immunology, v.66, p.4499-4502, 1998.

VEGA, C. A.; VERALDO, H. M. P.; GARCIA, F. E.; RIOS-LEAL, E. R.; VAZQUEZ, R. R. Effect of culture conditions on fatty acids composition of a biosurfactant produced by Candida ingens and changes of surface tension of culture media. Trends in Biotechnology, v.3, p.32-36, 2007.

VOLLENBROICH, D.; OZEL, M.; VATER, J.; KAMP, R. M.; PAULI, G. Mechanism of inactivation of enveloped viruses by the biosurfactant surfactin from Bacillus subtilis. Biologicals, n. 25, p. 289-297, 1997.

WEBER, L.; STACH, J.; HAUFE, G.; HOMMEL, R.; KLEBER, H. P. Elucidation of the structure of an unusual cyclic glycolipid from Torulopsis apicola. Carbohydrate Research, n. 206, p. 13-19, 1990.

WEI,Y. H.; CHOU, J. L.; CHANG, J. S. Rhamnolipid production by an indigenous isolate Pseudomonas aeruginosa J4 originating from petrochemical wastewater, Biochemical. Engineering Journal, v.2, p.146-154, 2005.

WHANG, L. M.; LIU, P. W. G.; MA, C. C.; CHENG, S. S. Application of biosurfactants, rhamnolipid, and surfactin, for enhanced biodegradation of diesel-contaminated water and soil. Journal of Hazardous Materials, 151, p.155-163, 2008.

WHANG, L. M.; LIU, P. W. G.; MA, C. C.; CHENG, S. S. Aplicação of rhamnolipid and surfactin for enhanced diesel biodegradation-Effects of $\mathrm{pH}$ and ammonium addition. Journal of Hazardous Materials, v. 164, 1045-1050, 2009. 
YAKIMOV, M. M.; GOLYSHIN, P. N.; LANG, S.; MOORE, E. R.; ABRAHAM, W. R.; LUNSDORF, H.; TIMMIS, K. N. International Journal Systems Bacteriology, v. 48, p. 339-348, 1998.

YEH, M.S.; WEI, Y.H.; CHANG, J.S. Enhanced production of surfactin from Bacillus subtilis by addition of solid carriers. Biotechnology Progress, v.21, p.1329-1334, 2005.

ZOUBOUliS, A. I.; MATIS, K. A.; LAZARIDIS, N. K.; GOLYSHIN, P. N. The use of biosurfactants in flotation: application for the removal of metal ions. Minerals Engineering, n. 16, p. 1231-1236, 2003. 